ORNL/CON-394

\title{
Oak Ridge National Laboratory Energy Efficiency and Renewable Energy Program
}

Bibliography

1994 Edition

K. H. Vaughan

MANAGED BY

MARTIN MARIETTA ENERGY SYSTEMS, INC. FOR THE UNITED STATES 
This report has been reproduced directly from the best available copy.

Available to DOE and DOE contractors from the Office of Scientific and Technical Information, P.O. Box 62, Oak Ridge, TN 37831; prices available from (615) 576-8401, FTS 626-8401.

Available to the public from the National Technical Information Service, U.S. Department of Commerce, 5285 Port Royal Rd., Springfield, VA 22161.

This report was prepared as an account of work sponsored by an agency of the United States Government. Neither the United States Government nor any agency thereof, nor any of their employees, makes any warranty, express or implied, or assumes any legal liability or responsibility for the accuracy, completeness, or usefulness of any information, apparatus, product, or process disclosed, or represents that its use would not infringe privately owned rights. Reference herein to any specific commercial product, process, or service by trade name, trademark, manufacturer, or otherwise, does not necessarily constitute or imply its endorsement, recommendation, or favoring by the United States Government or any agency thereof. The views and opinions of authors expressed herein do not necessarily state or reflect those of the United States Government or any agency thereof. 


\section{DISCLAIMER}

Portions of this document may be illegible in electronic image products. Images are produced from the best available original document. 
ORNLCON-394

\section{OAK RIDGE NATIONAL LABORATORY}

\section{ENERGY EFFICIENCY AND RENEWABLE ENERGY PROGRAM BIBLIOGRAPHY}

1994 Edition

Kathi H. Vaughan

Date Published—October 1994

Prepared by the

Oak Ridge National Laboratory

Oak Ridge, Tennessee 37831

managed by

MARTIN MARIETTA ENERGY SYSTEMS, INC.

for the

U.S. DEPARTMENT OF ENERGY

under contract DE-AC05-84OR21400 


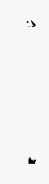




\section{Contents}

Page

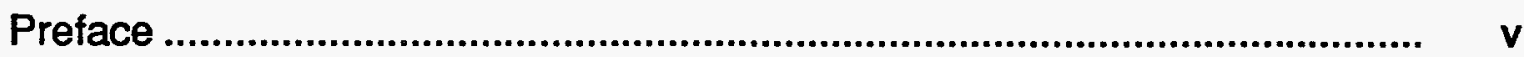

Analysis and Evaluation ....................................................................... 1

Building Equipment Research ................................................................. 11

Building Thermal Envelope Systems and Materials ................................... 19

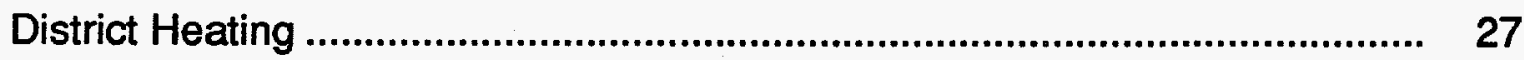

Residential and Commercial Conservation Program................................... 29

Weatherization Assistance Program ...................................................... 31

Existing Buildings Research Program ........................................................... 33

Ceramic Technology Project ..................................................................... 37

Alternative Fuels and Propulsion Technology ............................................. 57

Microemulsion Fuels ........................................................................... 61

Industrial Chemical Heat Pumps ........................................................... 63

Materials For Advanced Industrial Heat Exchangers ................................... 65

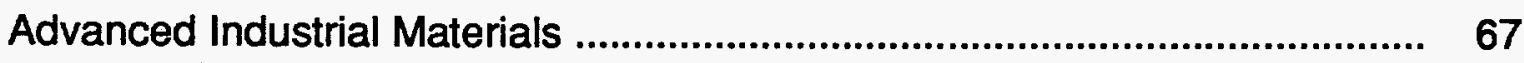

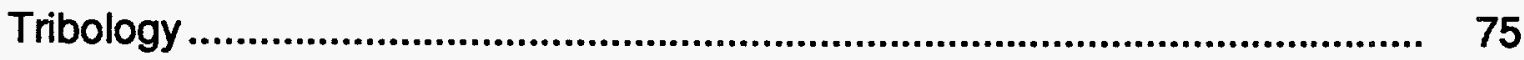

Energy-Related Inventions Program ....................................................... 77

Power Systems Technology ..................................................................... 79

Superconducting Technology Program for Electric Energy Systems............. 85

Thermal Energy Storage ......................................................................... 97

Biofuels Feedstock Development ............................................................. 101

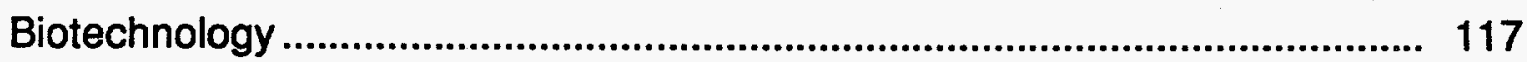

Continuous Chromatography In Multicomponent Separations ..................... 119

Sensors For Electrolytic Cells ................................................................ 121

Hydropower Environmental Mitigation ...................................................... 123

Environmental Control Technology ............................................................ 125

Continuous Fiber Ceramic Composite Technology ..................................... 127

Physical Chemistry of Geothermal Systems ................................................. 129 


\section{PREFACE}

The Bibliography contains listings of publicly available technical reports, journal articles, and conference papers resulting from Oak Ridge National Laboratory research and development projects sponsored by the Department of Energy, Office of Energy Efficiency and Renewable Energy, and published between 1989 and mid-1994. Over 200 citations have been added since the last edition.

\section{To Order Documents From This Bibliography}

Single copies of up to four documents may be requested by contacting Barbara Oody at:

$\begin{array}{ll}\text { E-mail: } & \text { oodybg@ornl.gov } \\ \text { Mail: } & \begin{array}{l}\text { Energy Efficiency and Renewable Energy Program } \\ \text { Oak Ridge National Laboratory }\end{array} \\ & \begin{array}{l}\text { P. O. Box 2008 } \\ \text { Oak Ridge TN 37831-6188 }\end{array} \\ \text { Fax: } & 615 / 576-7572 \\ \text { Voice: } & 615 / 574-5204\end{array}$

Items may also be obtained directly from the publisher, libraries, or other information service; or may be purchased from the National Technical Information Service (NTIS) at the address below. Codes are used for pricing all publications available through NTIS, and are based on the number of pages in the publication. Information pertaining to the pricing codes can be found in the current issue of the following publications which are generally available in most libraries: Energy Research Abstracts (ERA), Government Reports Announcements and Index (GRA and I); Scientific and Technical Abstract Reports (STAR); and publication NTIS-PR-360 available from NTIS at the following address.

National Technical Information Service

U.S. Department of Commerce

5285 Port Royal Road

Springfield VA 22161

Telephone 703/487-4650

To Order Documents Published In Prior Years

Information on documents published prior to 1989 can be obtained from Kathi Vaughan at:

$\begin{array}{ll}\text { E-mail: } & \text { vhk@ornl.gov } \\ \text { Mail: } & \text { Energy Efficiency and Renewable Energy Program } \\ & \text { Oak Ridge National Laboratory } \\ & \text { P. O. Box 2008 } \\ & \text { Oak Ridge TN 37831-6188 } \\ \text { Fax: } & 615 / 576-7572 \\ \text { Voice: } & 615 / 241-4292\end{array}$




\section{ANALYSIS AND EVALUATION}

1 Effects of Resource Acquisitions on Electric-Utility Shareholders ORNLCON-387 (May 1994)

E. Hirst. S. Hadley. Oak Ridge National Laboratory, Oak Ridge, Tenn.

$2 \quad I R P$ and the Utility of the Future

IRP Quarterly 9, pp. 26-30 (April 1994)

E. Hirst. Oak Ridge National Laboratory, Oak Ridge, Tenn.

3 Financial Comparison of Time-of-Use Pricing With Technical DSM Programs and Generating Plants as Electric-Utility Resource Options ORNLCON-352 (April 1994)

L. J. Hill. Oak Ridge National Laboratory, Oak Ridge, Tenn.

4 Electric-Utility DSM Programs in a Competitive Environment ORNL/CON-384 (April 1994)

E. Hirst. Oak Ridge National Laboratory, Oak Ridge, Tenn.

5 Perspectives on the Future of the Electric Utility Industry ORNLCON-385 (April 1994)

B. Tonn. Oak Ridge National Laboratory, Oak Ridge, Tenn.

A. Schaffhauser. University of Tennessee, Knoxville, Tenn.

6 Process Evaluation of the Regional Biomass Energy Program ORNL/CON-374 (March 1994)

C. R. Wilson. University of Tennessee, Knoxville, Tenn.

M. A. Brown, R. D. Perlack. Oak Ridge National Laboratory, Oak Ridge, Tenn.

7 Effects of Utility. Demand-Side Management Programs on Uncertainty Resource and Energy Economics 16(1), p. 25 (March 1994)

E. Hirst. Oak Ridge National Laboratory, Oak Ridge, Tenn.

8 The Role of Environmental Groups in Electric-Utility Regulation: A Case Study

The Electricity Joumal 7(2), pp. 66-76 (March 1994)

E. Hirst. Oak Ridge National Laboratory, Oak Ridge, Tenn.

9 Integrated Resource Planning: A Model Rule Public Util. Fortn. 131(6), p. 24 (March 1994)

E. Hirst. Oak Ridge National Laboratory, Oak Ridge, Tenn.

E. Blank, B. Driver. Land and Water Fund of the Rockies, Boulder, Col.

10 Effects of Utility Demand-Side Management Programs on Uncertainty Resource and Energy Economics 16, pp. 25-45 (1994)

E. Hirst. Oak Ridge National Laboratory, Oak Ridge, Tenn.

11 DSMIIRP Collaboratives: What Have They Accomplished Energy Sources 16(1), p. 161 (1994)

M. Schweitzer. Oak Ridge National Laboratory, Oak Ridge, Tenn.

M. English, J. Altman. University of Tennessee, Knoxville, Tenn. 
12 U.S. Department of Energy Integrated Resource Planning Program: Accomplishments and Opportunities

ORNL/CON-370 (December 1993)

D. L. White. Oak Ridge National Laboratory, Oak Ridge, Tenn.

P. E. Mihlmester. Aspen Systems Corp., Oak Ridge, Tenn.

13 DSM Today Through 2000

Electr. Perspect., pp. 65-67 (December 1993)

E. Hirst. Oak Ridge National Laboratory, Oak Ridge, Tenn.

14 Quantifying Regulatory Disincentives to Utility DSM Programs

Energy 18(11), p. 1091 (November 1993)

E. Hirst. Oak Ridge National Laboratory, Oak Ridge, Tenn.

E. Blank. Land and Water Fund of the Rockies, Boulder, Col.

15 An Introduction to Integrated Resource Planning

Public Power, pp. 40-47 (November 1993)

E. Hirst. Oak Ridge National Laboratory, Oak Ridge, Tenn.

16 The Role of Environmental Groups in Reforming Electric-Utility

Regulation: A Rocky Mountain Case Study

ORNLM-3068 (October 1993)

E. Hirst. Oak Ridge National Laboratory, Oak Ridge, Tenn.

17 Statistical Recoupling: A New Way to Break the Link Between ElectricUtility Sales and Revenues

ORNL/CON-372 (September 1993)

E. Hirst. Oak Ridge National Laboratory, Oak Ridge, Tenn.

18 Achievements of the Office of Technical and Financial Assistance Information Services Program: Analysis of Operations and Service Delivery

ORNL/CON-355 (May 1993)

D. L. White, M. S. Irby. Oak Ridge National Laboratory, Oak Ridge, Tenn.

M. A. Beyer. Aspen Systems Corp., Oak Ridge, Tenn.

19 Electric-Utility DSM-Program Costs and Effects: 1991 to 2001 ORNL/CON-364 (May 1993)

E. Hirst. Oak Ridge National Laboratory, Oak Ridge, Tenn.

20 Interactive Efforts to Address DSM and IRP Issues: Findings From the

First Year of a Two-Year Study

ORNL/CON-357 (April 1993)

M. Schweitzer. Oak Ridge National Laboratory, Oak Ridge, Tenn.

M. English, J. Altman. Energy, Environment, and Resources Center, University of

Tennessee, Knoxville, Tenn.

E. Yourstone. Consultant to Oak Ridge National Laboratory, Oak Ridge, Tenn.

21 A New Model of Incremental Decision Making for Resource Acquisition by Electric Utilities

Simulation 60(3), p. 196 (March 1993)

E. Hirst, M. Gettings. Oak Ridge National Laboratory, Oak Ridge, Tenn.

E. Yourstone. Consultant to Oak Ridge National Laboratory, Oak Ridge, Tenn. 
22 The Social Costs to the U.S. of Monopolization of the World Oil Market, 1972-1991

ORNL-6744 (March 1993)

D. L. Greene, P. N. Leiby. Oak Ridge National Laboratory, Oak Ridge, Tenn.

23 Transportation Energy Data Book: Edition 13

ORNL/6743 (Edition 13 of ORNL-5198) (March 1993)

S. C. Davis. Oak Ridge National Laboratory, Oak Ridge, Tenn.

S. G. Strang. University of Tennessee, Knoxville, Tenn.

24 Regulating as if Customers Matter: Utility Incentives to Affect Load Growth ORNL/M-2653 (January 1993)

E. Hirst. Oak Ridge National Laboratory, Oak Ridge, Tenn.

E. Blank. Land and Water Fund of the Rockies, Boulder, Col.

25 The Next Frontier for Integrated Resource Planning and Demand-Side Management

Electr. J. 6(1), pp. 44-50 (1993)

E. Hirst. Oak Ridge National Laboratory, Oak Ridge, Tenn.

P. Bradford. New York Public Service Commission, Albany, N.Y.

R. Cavanagh. Natural Resource Defense Council, San Francisco, Calif.

C. Harringston. Regulatory Assistance Project, Gardiner, Maine

A. Lovins. Rocky Mountain Institute, Estes Park, Col.

J. Rowe. New England Electric, Westborough, Mass.

S. Wiel. Lawrence Berkeley Laboratory, Berkeley, Calif.

26 A Good Integrated Resource Plan: Guidelines for Electric Utilities and Regulators

ORNL/CON-354 (December 1992)

E. Hirst. Oak Ridge National Laboratory, Oak Ridge, Tenn.

27 Electric-Utility DSM Programs: 1990 Data and Forecasts to 2000 ORNL-CON-347 (June 1992)

E. Hirst. Oak Ridge National Laboratory, Oak Ridge, Tenn.

28 Fleet Vehicles in the United States: Composition, Operating Characteristics, and Fueling Practices

ORNL-6717 (May 1992)

S.-P. Miaou, P. S. Hu. Oak Ridge National Laboratory, Oak Ridge, Tenn.

J. R. Young. University of Tennessee, Knoxville, Tenn.

29 Effects of Utility DSM Programs on Risk ORNL/CON-346 (May 1992)

E. Hirst. Oak Ridge National Laboratory, Oak Ridge, Tenn.

30 Transportation Energy Data Book: Edition 12 ORNL-6710 (Edition 12 of ORNL-5198) (March 1992)

S. C. Davis. Oak Ridge National Laboratory, Oak Ridge, Tenn.

M. D. Morris. University of Tennessee, Knoxville, Tenn.

31 The Demand-Side Management Program Development Process-A Utility Perspective

ORNLCON-345 (March 1992)

A. K. Wolfe. Oak Ridge National Laboratory, Oak Ridge, Tenn.

E. Yourstone. Consultant to Oak Ridge National Laboratory, Oak Ridge, Tenn. 
32 From DSM Technologies to DSM Programs: Issues in Demand-Side Planning for Electric Utilities

Energy 17(2), pp. 151-60 (February 1992)

L. J. Hill, E. Hirst, M. Schweitzer. Oak Ridge National Laboratory, Oak Ridge, Tenn.

33 Public Involvement in Integrated Resource Planning: A Study of DemandSide Management Collaboratives ORNLCON-344 (February 1992)

J. Raab. Consultant to Oak Ridge National Laboratory, Oak Ridge, Tenn.

M. Schweitzer. Oak Ridge National Laboratory, Oak Ridge, Tenn.

34 The Role of Evaluation When Electric Utilities Get Financial Incentives for Their DSM Programs

Evaluation Review 16(1), pp. 93-107 (February 1992)

E. Hirst. Oak Ridge National Laboratory, Oak Ridge, Tenn.

35 Making Energy Efficiency Happen

pp. 205-21, Technologies for a Greenhouse-Constrained Society, ed. M. A. Kuliasha, A.

Zucker, and K. J. Ballew (Chelsea, Mich.: Lewis Publishers, Inc., 1992)

E. Hirst. Oak Ridge National Laboratory, Oak Ridge, Tenn.

36 Data and Analysis Needed to Prepare an Electric-Utility Integrated Resource Plan

Proceedings of Clean Air Workshop, Columbus, Ohio, May 7-8, 1992 (National Regulatory Research Institute, 1992)

E. Hirst. Oak Ridge National Laboratory, Oak Ridge, Tenn.

37 Definitions and Tradeoffs: Cost-Effectiveness of Utility DSM Programs Proceedings ACEEE 1992 Summer Study on Energy Efficiency in Buildings , pp. 8.898.97 (Washington, D.C.: American Council for an Energy-Efficient Economy, 1992)

E. Hirst. Oak Ridge National Laboratory, Oak Ridge, Tenn.

38 Coming to Terms with DSM

Proceedings ACEEE 1992 Summer Study on Energy Efficiency in Buildings, pp. 7.203-

7.205 (Washington, D.C.: American Council for an Energy-Efficient Economy, 1992)

E. Hirst. Oak Ridge National Laboratory, Oak Ridge, Tenn.

C. Sabo. Barakat and Chamberlin, Inc., Washington, D.C.

39 The Context and Organization of Demand-Side Management Collaboratives: An Overview

Proceedings ACEEE 1992 Summer Study on Energy Efficiency in Buildings, pp. 8.1418.149 (Washington, D.C.: American Council for an Energy-Efficient Economy, 1992)

M. Schweitzer. Oak Ridge National Laboratory, Oak Ridge, Tenn.

J. Raab. Raab Associates, Boston, Mass.

40 The Reliability of Residential Energy Conservation Resources

Proceedings ACEEE 1992 Summer Study on Energy Efficiency in Buildings, pp. 7.2677.275 (Washington, D.C.: American Council for an Energy-Efficient Economy, 1992)

M. A. Brown, D. L. White. Oak Ridge National Laboratory, Oak Ridge, Tenn. 
41 Handbook of Evaluation of Utility DSM Programs

ORNLCON-336 (December 1991)

B. H. Bronfman. Bronfman \& Associates, Portland, Ore.

G. L. Fitzpatrick. Applied Energy Group, Inc., Woodbury, N.Y.

E. G. Hicks. New England Power Service Company, Westborough, Mass.

E. Hirst, J. H. Reed. Oak Ridge National Laboratory, Oak Ridge, Tenn.

M. G. Hoffman, H. Michaels, A. Schon. XENERGY, Burlington, Mass.

K. Keating. Bonneville Power Administration, Portland, Ore.

S. Nadel. American Council for an Energy-Efficient Economy, Washington, D. C.

J. S. Peters. Barakat \& Chamberlin, Inc., Portland, Ore.

W. Saxonis. New York State Energy Office, Albany, N.Y.

D. M. Violette. RCG/Hagler, Bailly, Inc., Boulder, Colo.

42 Comparison of Methods to Integrate DSM and Supply Resources in Eloctric-Utility Planning

ORNL/CON-341 (December 1991)

L. J. Hill. Oak Ridge National Laboratory, Oak Ridge, Tenn.

43 The Effects of Utility DSM Programs on Electricity Costs and Prices ORNL/CON-340 (November 1991)

E. Hirst. Oak Ridge National Laboratory, Oak Ridge, Tenn.

44 Electric-Utility DSM Programs: Terminology and Reporting Formats ORNL/CON-337 (October 1991)

E. Hirst. Oak Ridge National Laboratory, Oak Ridge, Tenn.

C. Sabo. Barakat \& Chamberlin, Inc., Washington, D. C.

45 Light-Duty Vehicle Summary: First Six Months of Model Vear 1991 ORNL-6672/S1 (August 1991)

P. S. Hu. Oak Ridge National Laboratory, Oak Ridge, Tenn.

46 Improving Energy Efficiency in the USA: The Federal Role Energy Policy, pp. 567-77 (July/August 1991)

E. Hirst. Oak Ridge National Laboratory, Oak Ridge, Tenn.

47 Highway Vehicle MPG and Market Shares Report: Model Year 1992 ORNL-6672 (April 1991)

L. S. Williams. University of Tennessee, Knoxville, Tenn.

P. S. Hu. Oak Ridge National Laboratory, Oak Ridge, Tenn.

48 Diamond: A Model of Incremental Decision Making for Resource Acquisition by Electric Utilities ORNLCON-315 (February 1991)

M. B. Gettings, E. Hirst. Oak Ridge National Laboratory, Oak Ridge, Tenn.

E. Yourstone. Consultant to Oak Ridge National Laboratory, Oak Ridge, Tenn.

49 Demand-Side Management and Integrated Resource Planning: Findings From a Survey of 24 Electric Utilities ORNLCON-314 (February 1991)

M. Schweitzer, E. Hirst, L. J. Hill. Oak Ridge National Laboratory, Oak Ridge, Tenn.

50 Transportation Energy Data Book: Edition 11

ORNL-6649 (Edition 11 of ORNL-5198) (January 1991)

S. C. Davis, P. S. Hu. Oak Ridge National Laboratory, Oak Ridge, Tenn. 
51 Integrating Demand-Side Management Programs into the Resource Plans of U.S. Electric Utilities ORNL/CON-311 (January 1991) L. J. Hill, E. Hirst, M. Schweitzer. Oak Ridge National Laboratory, Oak Ridge, Tenn.

52 Possible Effects of Electric-Utility DSM Programs, 1990 to 2010 ORNLCON-312 (January 1991)

E. Hirst. Oak Ridge National Laboratory, Oak Ridge, Tenn.

53 Commercializing Government-Sponsored Computer Software

Advances in the Implementation and Impact of Computer Systems, ed. M. Fleisher and J. Morrell, pp. 263-75 (Greenwich, Conn.: JAI Press, 1991)

R. K. Goel, M. A. Brown. Oak Ridge National Laboratory, Oak Ridge, Tenn.

54 Evaluating Demand-Side Management Programs

Electric Perspectives 14(6), pp. 24-30 (November/December 1990)

E. Hirst. Oak Ridge National Laboratory, Oak Ridge, Tenn.

55 Balancing the Scales: Data on Electricity Supply and Demand Resources ORNL/CON-306 (September 1990)

E. Hirst. Oak Ridge National Laboratory, Oak Ridge, Tenn.

56 Energy Efficiency in Nonprofit Agencies: Creating Effective Program Models

ORNLTM-11602 (August 1990)

M. A. Brown, D. L. White. Oak Ridge National Laboratory, Oak Ridge, Tenn.

B. Prindle. Alliance to Save Energy, Washington, D. C.

M. I. Scherr. United Way of America, Alexandria, Va.

57 Electricity, Getting More With Less

Technology Review 93(5), pp. 32-40 (July 1990)

E. Hirst. Oak Ridge National Laboratory, Oak Ridge, Tenn.

58 Closing The Efficiency Gap: Barriers to Improving Energy Efficiency Resources, Conservation and Recycling 3, pp. 276-81 (June 1990)

M. A. Brown, E. Hirst. Oak Ridge National Laboratory, Oak Ridge, Tenn.

59 Demand-Side Data Needs for Least-Cost Utility Planning

Energy 15(5), pp. 403-12 (May 1990)

E. Hirst. Oak Ridge National Laboratory, Oak Ridge, Tenn.

C. Goldman. Lawrence Berkeley Laboratory, Berkeley, Calif.

60 Balancing the Scales: Toward Parity in Electric Supply and Demand Data The Electricity Journal 3(4), pp. 28-33 (May 1990)

E. A. Hirst. Oak Ridge National Laboratory, Oak Ridge, Tenn.

61 Key Issues in Electric Utility Integrated Resource Planning: Findings from a Nationwide Study

ORNL/CON-300 (April 1990)

M. Schweitzer, E. Hirst. Oak Ridge National Laboratory, Oak Ridge, Tenn.

E. Yourstone. Consultant to Oak Ridge National Laboratory, Oak Ridge, Tenn.

62 Progress and Potential in Evaluating Energy-Efficiency Programs

Evaluation Review 14(2), pp. 192-205 (April 1990)

E. Hirst. Oak Ridge National Laboratory, Oak Ridge, Tenn. 
63 The Market Penetration of Energy-Efficiency Programs ORNL/CON-299 (April 1990)

L. Berry. Oak Ridge National Laboratory, Oak Ridge, Tenn.

64 Light-Duty Vehicle MPG and Market Shares Report: Model Year 1989 ORNL-6626 (April 1990)

L. S. Williams. University of Tennessee, Knoxville, Tenn.

P. S. Hu. Oak Ridge National Laboratory, Oak Ridge, Tenn.

65 Why The Federal Government Should Help Improve U.S. Energy Efficiency

Ambio, A Journal of the Human Environment XIX(2), pp. 96-98 (April 1990)

E. Hirst. Oak Ridge National Laboratory, Oak Ridge, Tenn.

66 Demonstrations as a Policy Instrument with Energy Technology Examples Knowledge: Creation, Diffusion, and Utilization 11(3): pp. 219-36 (March 1990)

S. M. Macey. Southwest Texas State University, San Marcos, Texas

M. A. Brown. Oak Ridge National Laboratory, Oak Ridge, Tenn.

67 Guidelines for a "Good" Integrated Resource Plan

Public Utilities Fortnightly 125(7), pp. 18-24 (March 1990)

E. Hirst. Oak Ridge National Laboratory, Oak Ridge, Tenn.

68 Assessing Integrated Resource Plans Prepared by Electric Utilities ORNL/CON-298 (February 1990)

E. Hirst, M. Schweitzer. Oak Ridge National Laboratory, Oak Ridge, Tenn.

E. Yourstone. Consultant to Oak Ridge National Laboratory, Oak Ridge, Tenn.

J. Eto. Lawrence Berkeley Laboratory, Berkeley, Calif.

69 Energy Efficiency: How Far Can We Go?

ORNLTM-11441 (January 1990)

R. S. Carlsmith. Oak Ridge National Laboratory, Oak Ridge, Tenn.

W. U. Chandler. Battelle-Pacific Northwest Laboratories, Washington, D.C.

J. E. McMahon. Lawrence Berkeley Laboratory, Berkeley, Calif.

D. J. Santini. Argonne National Laboratory, Argonne, III.

70 The Technology Transfer Process: Background for the U.S. National Energy Strategy

PNL-SA-17482* (Richland, Wash.: Pacific Northwest Laboratory, January 1990)

D. E. Deonigi, N. L. Moore, S. A. Smith, R. L. Watts. Pacific Northwest Laboratory,

Richland, Wash.

M. A. Brown. Oak Ridge National Laboratory, Oak Ridge, Tenn.

R. J. Noun. Solar Energy Research Institute, Golden, Colo.

71 Flexibility Benefits of Demand-Side Programs in Utility Planning The Energy Journal 11(1), pp. 151-65 (1990)

E. Hirst. Oak Ridge National Laboratory, Oak Ridge, Tenn.

72 Technology-Transfer Strategies of DOE's Conservation Programs Journal of Technology Transfer 15(1), pp. 33-40 (1990)

M. A. Brown. Oak Ridge National Laboratory, Oak Ridge, Tenn.

C. H. Major. U.S. Department of Energy, Office of Conservation and Renewable Energy, Washington, D. C.

*Available from Pacific Northwest Laboratory, Post Office Box 999, Richland, Washington 99352. 
73 Electric-Utility Resource Planning and Decision Making: The Importance of Uncertainty

Risk Analysis 10(1), pp. 137-46 (1990)

E. Hirst, M. Schweitzer. Oak Ridge National Laboratory, Oak Ridge, Tenn.

74 Data Requirements for Utility Integrated Resource Planning Energy Systems \& Policy 12(4), pp. 219-31 (December 1989)

E. Hirst. Oak Ridge National Laboratory, Oak Ridge, Tenn.

75 Conservation Programs Can Cut Load-Growth Uncertainty for Electric Utilities

Technological Forecasting and Social Change 36(4), pp. 415-24 (December 1989)

E. Hirst. Oak Ridge National Laboratory, Oak Ridge, Tenn.

76 The Administrative Costs of Energy Conservation Programs ORNLCON-294 (November 1989)

L. Berry. Oak Ridge National Laboratory, Oak Ridge, Tenn.

77 Comparison of EIA Data Collections: Electricity Supply and Demand ORNL/M-998 (October 1989)

E. Hirst. Oak Ridge National Laboratory, Oak Ridge, Tenn.

78 Federal Roles to Realize National Energy-Efficiency Opportunities in the $1990 \mathrm{~s}$

ORNL/CON-290 (October 1989)

E. Hirst. Oak Ridge National Laboratory, Oak Ridge, Tenn.

79 Comparing Building Energy Analysis Software

Home Energy 6(5), pp. 13-18 (September/October 1989)

P. Weiss. Consultant to Oak Ridge National Laboratory, Oak Ridge, Tenn.

M. A. Brown. Oak Ridge National Laboratory, Oak Ridge, Tenn.

80 Transportation Energy Data Book: Edition 10

ORNL-6565 (edition 10 of ORNL-5198) (September 1989)

S. C. Davis. University of Tennessee, Knoxville, Tenn.

D. B. Shonka. Shonka Research Associates, Inc., Marietta, Ga.

G. J. Anderson-Batiste, P. S. Hu. Oak Ridge National Laboratory, Oak Ridge, Tenn.

81 Energy Use and Consumer Dissimilarity in Multifamily Residential Conservation

Proceedings of the National Energy Program Evaluation Conference, Chicago, August 23-25, 1989, pp. 219-24 (Argonne, III.: Argonne National Laboratory, August 1989)

D. L. White. Oak Ridge National Laboratory, Oak Ridge, Tenn.

82 Recent Accomplishments of the U.S. Department of Energy's Least-Cost Utility Planning Program

ORNL/CON-288 (August 1989)

L. Berry, E. Hirst. Oak Ridge National Laboratory, Oak Ridge, Tenn.

83 Light-Duty Vehicle Summary: Model Year 1976 to the First Half of Model Year 1989

ORNL/M-916 (August 1989)

L. S. Williams. University of Tennessee, Knoxville, Tenn.

P. S. Hu. Oak Ridge National Laboratory, Oak Ridge, Tenn. 
84 Electric-Utility Energy-Efficiency and Load-Management Programs:

Resources for the 1990s

ORNL/CON-285 (June 1989)

E. Hirst. Oak Ridge National Laboratory, Oak Ridge, Tenn.

85 Least-Cost Planning in the Utility Sector: Progress and Challenges.

Volume 2: Technical Appendix

LBL-27131* (June 1989)

C. Goldman, F. Krause, eds. Lawrence Berkeley Laboratory, Berkeley, Calif.

E. Hirst, ed. Oak Ridge National Laboratory, Oak Ridge, Tenn.

86 Least-Cost Planning in the Utility Sector: Progress and Challenges ORNLCON-284 (May 1989)

C. Goldman, F. Krause, eds. Lawrence Berkeley Laboratory, Berkeley, Calif.

E. Hirst, ed. Oak Ridge National Laboratory, Oak Ridge, Tenn.

87 Light-Duty Vehicle MPG and Market Shares Report: Model Year 1988 ORNL-6549 (April 1989)

P. S. Hu. Oak Ridge National Laboratory, Oak Ridge, Tenn.

L. S. Williams, D. J. Beal. University of Tennessee, Knoxville, Tenn.

88 Benefits and Costs of Small, Short-Lead-Time Power Plants and DemandSide Programs in an Era of Load-Growth Uncertainty ORNL/CON-278 (March 1989)

E. A. Hirst. Oak Ridge National Laboratory, Oak Ridge, Tenn.

89 Recent Publications of DOE's Office of Buildings and Community Systems ORNL/CON-276 (February 1989)

M. A. Brown. Oak Ridge National Laboratory, Oak Ridge, Tenn.

J. Hayes. Applied Management Sciences, Oak Ridge, Tenn.

90 Integrated Resource Planning at Electric Utilities: The Planning Process Evaluation and Program Planning 12, pp. 213-23 (1989)

E. Hirst. Oak Ridge National Laboratory, Oak Ridge, Tenn.

*Available from the University of California, Lawrence Berkeley Laboratory, One Cyclotron Road, Berkeley, California 94720. 



\section{BUILDING EQUIPMENT RESEARCH}

91 Heat Pump Systems With Direct Expansion Ground Coils pp. 40-1-40-21 in Proceedings, Meeting Customer Needs with Heat Pumps, Dallas, October 15-19, 1991 , EPRI/TR-101944 (Palo Alto, Calif.: Electric Power Research Institute, December 1993)

O. J. Svec. National Research Council of Canada, Ottawa, Canada

V. D. Baxter. Oak Ridge National Laboratory, Oak Ridge, Tenn.

92 Facts About Triple-Effect Absorption Chiller Cycles Gas Industries, pp. 26-28 (September 1993)

R. C. DeVault. Oak Ridge National Laboratory, Oak Ridge, Tenn.

G. Grossman. Technion Israel Institute of Technology, Haifa, Israel

93 Enhanced Absorption Cycle Computer Model

ORNL/Sub/1-SH641/1 (September 1993)

G. Grossman, M. Wilk. Technion Israel Institute of Technology, Haifa, Israel

94 Space Conditioning Options in the North: What Is Here and What May Come DSM Quarterty, pp. 11-20 (Summer 1993)

P. J. Hughes. Oak Ridge National Laboratory, Oak Ridge, Tenn.

95 Heat Pump Technology: Responding to New Opportunities pp. 563-72 in Heat Pumps for Energy Efficiency and Environmental Progress: Proceedings 4th International Energy Agency Heat Pump Conference, Maastricht, Nethenlands, April 26-29, 1993 (Amsterdam; New York: Elsevier Science Publishing, 1993)

V. D. Baxter, F. A. Creswick. Oak Ridge National Laboratory, Oak Ridge, Tenn.

W. K. Snelson. National Research Council of Canada, Ottawa, Canada

96 Gas-Fueled Space Conditioning Heat Pump Research in the United States

Heat Pumps for Energy Efficiency and Environmental Progress: Proceedings 4th International Energy Agency Heat Pump Conference, Maastricht, Netherlands, April 2629, 1993 (Amsterdam; New York: Elsevier Science Publishing, 1993)

G. H. Myers, S. I. Freedman, C. E. French. Gas Research Institute, Chicago, III.

R. C. DeVault. Oak Ridge National Laboratory, Oak Ridge, Tenn.

97 Compressor Calorimeter Performance of Refrigerant Blends-

Comparative Methods and Results for a Refrigerator/Freezer Application

ASHRAE Transactions 99(1), pp. 1447-66 (Atlanta: American Society of Heating,

Refrigerating, and Air-conditioning Engineers, 1993)

C. K. Rice, J. R. Sand. Oak Ridge National Laboratory, Oak Ridge, Tenn.

98 Laboratory Evaluation of an Ozone-Safe Nonazeotropic Refrigerant Mixture in a Lorenz-Meutzner Refrigerator Freezer Design ASHRAE Trans 99(1), pp. 1467-81 (Atlanta: American Society of Heating, Refrigerating, and Air-conditioning Engineers, 1993)

J. R. Sand, E. A. Vineyard, V. D. Baxter. Oak Ridge National Laboratory, Oak Ridge, Tenn. 
99 An Environmental Rating for Heat Pump Equipment p. 67 in Proceedings Joint U.S./Canada Workshop on Heat Pump Standards for Performance Rating, Toronto, December 7-8, 1992 (1993)

P. J. Hughes. Oak Ridge National Laboratory, Oak Ridge, Tenn.

100 The Role of Gas Heat Pumps in Electric DSM

p. 159 in Proceedings 6th National Demand-Side Management Conference, Miami

Beach, Fla., March 24-26 1993 (1993)

M. Fulmer. Tellus Institute, Boston, Mass.

P. J. Hughes. Oak Ridge National Laboratory, Oak Ridge, Tenn.

101 Refrigeration and Air-Conditioning Technology Workshop: Proceedings of the 1939 Non-Fluorocarbon Refrigeration and Air-Conditioning Technology Workshop, Breckenridge, Colorado, June 23-25, 1993 ORNL-6797 (1993)

P. J. Lewis, D. M. Counce, eds. Oak Ridge National Laboratory, Oak Ridge, Tenn.

102 Report Style Guide for Subcontractors of the Efficiency and Renewables Research Section, Energy Division, Oak Ridge National Laboratory ORNL/TM-12082 (September 1992)

T. A. Stone, M. N. Bennett. Oak Ridge National Laboratory, Oak Ridge, Tenn.

103 An Assessment of Desiccant Cooling and Dehumidification Technology ORNL/CON-309 (July 1992)

V. C. Mei, F. C. Chen. Oak Ridge National Laboratory, Oak Ridge, Tenn.

Z. Lavan. Illinois Institute of Technology, Chicago, III.

R. K. Collier, Jr. Collier Engineering Services, Merritt Island, Fla.

G. Meckler. Gershon Meckler Associates, P.C., Herndon, Va.

104 Global Warming Implication of Replacing CFCs: Combining Energy and Fluorocarbon Emission Effects

ASHRAE Journal 34(4), pp. 14-19 (April 1992)

S. K. Fischer, P. D. Fairchild, P. J. Hughes. Oak Ridge National Laboratory, Oak Ridge,

Tenn.

105 Development and Proof-Testing of Advanced Absorption Refrigeration Cycle Concepts. Report on Phases I and IA

ORNL/Sub/86-17498/1 (March 1992)

R. J. Modahl, F. C. Hayes. The Trane Company, La Crosse, Wisc.

106 Alternatives to CFCs and Global Warming: A Systems Approach to Evaluating Net Contributions

Materials Research Society Bulletin XVII(3), pp. 39-42 (March 1992)

S. K. Fischer. Oak Ridge National Laboratory, Oak Ridge, Tenn.

M. McFarland. E. I. du Pont de Nemours \& Co., Inc., Wilmington, Del.

107 Modeled Performance of Non-Chlorinated Substitutes for CFC-11 and CFC-12 Centrifugal Chillers

ORNL/M-2391 (1992)

J. R. Sand, S. K. Fischer. Oak Ridge National Laboratory, Oak Ridge, Tenn. 
108 Market Potential Estimates and R\&D Planning for Advanced Absorption Systems for Large Commercial Buildings

ASHRAE Transactions 98(2), pp. 156-64 (Atlanta, Ga.: American Society of Heating, Refrigerating, and Air-conditioning Engineers, 1992)

J. M. MacDonald, P. J. Hughes, H. A. McLain. Oak Ridge National Laboratory, Oak Ridge, Tenn.

109 Flow Boiling Enhancement of R22 and a Nonazeotropic Mixture of R143a and R124 Using Perforated Foils

ASHRAE Transactions 98(2), pp. 402-10 (Atlanta, Ga.: American Society of Heating, Refrigerating, and Air-conditioning Engineers, 1992)

J. C. Conklin, E. A. Vineyard. Oak Ridge National Laboratory, Oak Ridge, Tenn.

110 An Analytical Screening of Alternatives for R-502 in Low-Temperature Refrigerating Applications

ASHRAE Transactions 98(2), pp. 188-203 (Atlanta, Ga.: American Society of Heating, Refrigerating, and Air-conditioning Engineers, 1992)

S. K. Fischer. Oak Ridge National Laboratory, Oak Ridge, Tenn.

111 Benchmark Performance Analysis of an ECM-Modulated Air-to-Air Heat Pump with a Reciprocating Compressor

ASHRAE Transactions 98(1), pp. 430-50 (Atlanta, Ga.: American Society of Heating,

Refrigerating, and Air-conditioning Engineers, 1992)

C. K. Rice. Oak Ridge National Laboratory, Oak Ridge, Tenn.

112 Modeled Performance of Non-Chlorinated Substitutes for CFC-11 and CFC-12 in Centrifugal Chillers

Proceedings of the 1991 International CFC and Halon Alternatives Conference, Baltimore, Md., December 3-12, 1991 (Baltimore, Md.: December 1991)

J. R. Sand, S. K. Fischer. Oak Ridge National Laboratory, Oak Ridge, Tenn.

P. A. Joyner. Electric Power Research Institute, Palo Alto, Calif.

113 Total Equivalent Global Warming Impact: Combining Energy and Fluorocarbon Emission Effects

Proceedings of the 1991 International CFC and Halon Alternatives Conference, Baltimore, Md., December 3-12, 1991, pp. 790-800 (Baltimore, Md.: December 1991) P. D. Fairchild, S. K. Fischer, P. J. Hughes. Oak Ridge National Laboratory, Oak Ridge, Tenn.

114 Absorption Chillers: Part of the Solution Proceedings of the 1991 International CFC and Halon Alternatives Conference, Baltimore, Md., December 3-12, 1991, pp. 364-74 (Baltimore, Md.: December 1991) P. J. Hughes. Oak Ridge National Laboratory, Oak Ridge, Tenn.

A. J. Occhionero. American Gas Cooling Center, Arlington, Va.

E. A. Reid. Columbia Gas Distribution Company, Columbus, Ohio

115 Analysis of Non-CFC Automotive Air Conditioning

Proceedings of the 1991 International CFC and Halon Alternatives Conference, Baltimore, Md., December 3-12, 1991 (Baltimore, Md.: December 1991) V. C. Mei, F. C. Chen. Oak Ridge National Laboratory, Oak Ridge, Tenn.

R. Sullivan. Office of Energy Efficiency and Renewable Energy, U.S. Department of Energy, Washington, D. C. 
116 Overview of CFC Replacement Issues for Household Refrigeration Proceedings of the 1991 International CFC and Halon Alternatives Conference, Baltimore, Md., December 3-12, 1991, pp. 310-16 (Baltimore, Md.: December 1991) E. A. Vineyard. Oak Ridge National Laboratory, Oak Ridge, Tenn. L. Roke. Fisher \& Paykel, Greenmount, Auckland, New Zealand F. Hallett. Frigidaire, Washington, D. C.

117 Computer Model for Simulation of Absorption Systems in Flexible and Modular Form

ORNL/Sub/90-89673 (August 1991)

G. Grossman, K. Gommed, D. Gadoth. Technion Israel Institute of Technology, Haifa, Israel

118 Estimated Size and Performance of a Natural Gas Fired Duplex Stirling for Domestic Refrigeration Applications

Proceedings of the XVIII International Congress of Refrigeration, Montreal, Canada, August 10-15, 1991 (Paris: International Institute of Refrigeration, 1991)

D. M. Berchowitz. Sunpower, Inc., Athens, Ohio

J. A. Shonder. Oak Ridge National Laboratory, Oak Ridge, Tenn.

119 Heat Exchanger Thermal Performance for Two Nonazeotropic Refrigerant Mixtures

Proceedings of the XVIII International Congress of Refrigeration, Montreal, Canada, August 10-15, 1991 (Paris: International Institute of Refrigeration, 1991)

J. C. Conklin, E. A. Vineyard. Oak Ridge National Laboratory, Oak Ridge, Tenn.

120 Advantages of Enthalpy-Temperature Diagrams for Nonazeotropic Refrigerant Mixtures

Proceedings of the XVIII Intemational Congress of Refrigeration, Montreal, Canada, August 10-15, 1991 (Paris: International Institute of Refrigeration, 1991)

J. C. Conklin, J. R. Sand. Oak Ridge National Laboratory, Oak Ridge, Tenn.

E. Granryd. Royal Institute of Technology, Stockholm, Sweden

121 Cycle Performance Comparison Between A Nonazeotropic Refrigerant Mixture and $R-22$

Proceedings of the XVIII Intemational Congress of Refrigeration, Montreal, Canada, August 10-15, 1991 (Paris: International Institute of Refrigeration, 1991)

E. A. Vineyard, J. C. Conklin. Oak Ridge National Laboratory, Oak Ridge, Tenn.

122 Tubeside Condensation of Nonazeotropic Refrigerant Mixtures for Two Enhanced Surfaces

Proceedings of the ASME/JSME Thermal Engineering Joint Conference 3, pp. 251-56

(New York: American Society of Mechanical Engineers, March 1991)

J. C. Conklin, E. A. Vineyard. Oak Ridge National Laboratory, Oak Ridge, Tenn.

123 Heat Transfer of Buried Pipe for Heat Pump Application

ASME Journal of Solar Energy Engineering 113, pp. 51-55 (February 1991)

V. C. Mei. Oak Ridge National Laboratory, Oak Ridge, Tenn.

124 Braun Heat Pump Engine/Compressor and its Hermetic Rod Seal Proceedings of the 26th Intersociety Energy Conversion Engineering Workshop, Boston, Massachusetts, August 1991 91-2, p. 510 (LaGrange Park, III.: American Nuclear Society, Inc., August 1991)

A. T. Braun, M. S. Alam. Tectonics Research, Inc., Minneapolis, Minn.

R. J. Fiskum. Office of Energy Efficiency and Renewable Energy, U.S. Department of Energy, Washington, D. C. 
125 Options of Desiccant Cooling and Dehumidification Technology Proceedings of the 26th Intersociety Energy Conversion Engineering Workshop, Boston, Massachusetts, August 1991 91-2, p. 566 (LaGrange Park, III.: American Nuclear Society, Inc., August 1991)

E. Kweller. Office of Energy Efficiency and Renewable Energy, U.S. Department of Energy, Washington, D. C.

V. C. Mei, F. C. Chen. Oak Ridge National Laboratory, Oak Ridge, Tenn.

126 Residential Absorption Heat Pump Using a Generator-Absorber Heat Exchange Cycle

Proceedings of the 26th Intersociety Energy Conversion Engineering Workshop, Boston, Massachusetts, August 1991 91-2, p. 498 (LaGrange Park, III.: American Nuclear Society, Inc., August 1991)

B. A. Phillips. Phillips Engineering Company, St. Joseph, Mich.

R. C. DeVault. Oak Ridge National Laboratory, Oak Ridge, Tenn.

127 Natural Gas Fueled Combustor for a $3 \mathrm{~kW}$ Output Stirling Engine Proceedings of the 26th Intersociety Energy Conversion Engineering Workshop, Boston, Massachusetts, August 1991 91-2, p. 566 (LaGrange Park, IIl.: American Nuclear Society, Inc., August 1991)

W. D. Waldron, G. T. Riecke. Mechanical Technology, Inc., Latham, N.Y.

128 Experimental Study of the Effects of Alcohol Additives in Lithium Bromide Water Pool Absorbers

ASHRAE Transactions 97(2), pp. 403-405 (Atlanta: American Society of Heating,

Refrigerating, and Air-conditioning Engineers, 1991)

Y. Elkassabgi. Texas A\&I University, Kingsville, Texas

H. Perez-Blanco. Pennsylvania State University, University Park, Penn.

129 The Alternative Refrigerant Dilemma for Refrigerator-Freezers: Truth or Consequences

ASHRAE Transactions 97(2), pp. 955-60 (Atlanta: American Society of Heating,

Refrigerating, and Air-conditioning Engineers, 1991)

E. A. Vineyard. Oak Ridge National Laboratory, Oak Ridge, Tenn.

130 Thermal Performance Analysis for Heat Exchangers Using Nonazeotropic Refrigerant Mixtures

Proceedings Winter Meeting ASME, Dallas, Texas, November 25-30, 1990, Symposium on Heat Transfer in Advanced Energy Systems AES 18/HTD 151, pp. 25-32 (New

York: American Society of Mechanical Engineers, November 1990)

E. Granryd. Royal Institute of Technology, Stockholm, Sweden

J. C. Conklin. Oak Ridge National Laboratory, Oak Ridge, Tenn.

131 Development of a High-Efficiency, Gas-Fired, Absorption Heat Pump for Residential and Small-Commercial Applications. Phase I Final Report. Analysis of Advanced Cycles and Selection of the Preferred Cycle ORNL/Sub/86-24610/1 (September 1990)

B. A. Phillips. Phillips Engineering Co., St. Joseph, Mich.

132 Performance Testing of a Commercially Produced Cryogenic Refrigerator ORNL/TM-10809 (September 1990)

E. G. Keshock. University of Tennessee, Knoxville, Tenn.

R. W. Murphy. Oak Ridge National Laboratory, Oak Ridge, Tenn. 
133 Initial Parametric Results Using CYCLEZ-An LMTD-Specified, LorenzMeutzner Cycle Refrigerator-Freezer Model

ASHRAE/Purdue CFC Conference Proceedings, pp. 448-58 (West Lafayette, Ind.:

Purdue University, July 1990)

C. K. Rice, J. R. Sand. Oak Ridge National Laboratory, Oak Ridge, Tenn.

134 Thermodynamic Calculations for Mixtures of Environmentally Safe

Refrigerants Using the Lee-Kesler-Plöcker Equation of State

ASHRAE/Purdue CFC Conference Proceedings, pp. 373-82 (West Lafayette, Ind.:

Purdue University, July 1990)

S. K. Fischer, J. R. Sand. Oak Ridge National Laboratory, Oak Ridge, Tenn.

135 Energy Use Impact of CFC Alternatives

Proceedings of the Fifth Cogeneration and Independent Power Congress, 1990 HVAC

\& Controls Symposium \& Expo Section (Boston, Mass.: Association of Energy

Engineers, June 1990)

S. K. Fischer. Oak Ridge National Laboratory, Oak Ridge, Tenn.

136 Development of Design Guidelines for Direct Expansion Ground Coil Heat Exchangers for Ground Coupled Heat Pump Systems

EPRI CU-6828 (Palo Alto, Calif:: Electric Power Research Institute, May 1990)

V. C. Mei, V. D. Baxter. Oak Ridge National Laboratory, Oak Ridge, Tenn.

137 An Experimental Evaluation of Two Nonazeotropic Refrigerant Mixtures in a Water-to-Water, Breadboard Heat Pump ORNL/M-1117 (April 1990)

M. Kauffield, W. Mulroy, M. McLinden, D. Didion. National Institute of Standards and Technology, Gaithersburg, Md.

138 Triple Effect Absorption Chiller Cycle: A Step Beyond Double-Effect Cycles

Proceedings of the IEA Annex XVI Workshop on High Performance Heat Pumps, Susono

City, Japan, Report No. HPB-WR-6, pp. II-27-40 (March 1990)

R. C. DeVault. Oak Ridge National Laboratory, Oak Ridge, Tenn.

139 A Menu-Driven Program for Determining Properties of Aqueous Lithium Bromide Solutions ORNLTM-11331 (January 1990)

M. R. Patterson, H. Perez-Blanco. Oak Ridge National Laboratory, Oak Ridge, Tenn.

R. N. Crosswhite. Oak Ridge Associated Universities, Oak Ridge, Tenn.

140 A Magnetically Coupled Stirling Engine Driven Heat Pump: Design Optimization and Operating Cost Analysis

Proceedings of the 25th Intersociety Energy Conversion Engineering Conference , 2, pp. 204-10 (New York: American Institute of Chemical Engineers, 1990)

R. J. Vincent, W. Waldron. Mechanical Technology, Inc., Latham, N.Y.

141 Study of Asymmetric Supersonic Jet Flow for Ejectors

Thermo-Physical Aspects of Energy Conversion, AES 16, pp. 55-66 (New York:

American Society of Mechanical Engineers, 1990)

C. M. Ho. University of Southern California, Los Angeles, Calif.

G. S. Knoke. BDM Inc., Seattle, Wash.

E. W. Geller, H. T. Liu. Flow Research, Inc., Kent, Wash.

W. H. Jou. Flow Research, Inc., Seattle, Wash.

R. W. Murphy, F. C. Chen. Oak Ridge National Laboratory, Oak Ridge, Tenn. 
142 Hardware Development and Initial Subassembly Test of a Gas-Fired Stirling-Rankine Residential Heat Pump

Proceedings of the 25th Intersociety Energy Conversion Engineering Conference, 5, pp. 258-63 (New York: American Institute of Chemical Engineers, 1990)

$G$. Chen, J. McEntee. Sunpower, Inc., Athens, Ohio

143 Advanced Absorption Technology Development in the United States Heat Pumps Solving Energy and Environmental Challenges. Proceedings IEA Heat Pump Conference, Tokyo, Japan, March 12-15, 1990, pp. 69-80 (Pergamon Press, 1990)

R. C. DeVault. Oak Ridge National Laboratory, Oak Ridge, Tenn.

144 Performances of Four Magnetic Heat Pump Cycles

Thermo-Physical Aspects of Energy Conversion, AES 16, pp. 103-15 (New York:

American Society of Mechanical Engineers, 1990)

F. C. Chen, R. W. Murphy, V. C. Mei. Oak Ridge National Laboratory, Oak Ridge, Tenn.

G. L. Chen. Sunpower, Inc., Athens, Ohio

145 Energy Technology R\&D and the Greenhouse Effect

Heat Pumps Solving Energy and Environmental Challenges. Proceedings of the IEA

Heat Pump Conference, Tokyo, Japan, March 12-15, 1990, pp. 231-41 (Pergamon

Press, 1990)

P. D. Fairchild, W. Fulkerson. Oak Ridge National Laboratory, Oak Ridge, Tenn.

146 Absorption Fluids Data Survey. 1989 Update ORNL/Sub/84-47989/4 (October 1989)

R. A. Macriss, T. S. Zawacki. Institute of Gas Technology, Chicago, III.

147 Free-Piston Stirling Engine Magnetically Coupled Heat Pump: Critical Component Evaluation. Phase I Final Report

ORNL/Sub/86-SA578/1 (August 1989)

G. Chen. Sunpower, Inc., Athens, Ohio

148 Laboratory Study of the Dynamic Losses of a Single Speed, Split System Air-to-Air Heat Pump Having Tube and Plate Fin Heat Exchangers ORNL/CON-253 (August 1989)

W. A. Miller. Oak Ridge National Laboratory, Oak Ridge, Tenn.

149 Selection of Ozone-Free, Nonazeotropic Refrigerant Mixtures for Capacity Modulation in Residential Heat Pumps

ASHRAE Transactions 95(1), pp. 34-46 (Atlanta: American Society of Heating, Refrigerating, and Air-Conditioning Engineers, June 1989)

E. A. Vineyard, J. R. Sand. Oak Ridge National Laboratory, Oak Ridge, Tenn.

T. G. Statt. Department of Energy, Washington, D.C.

150 Refrigerator-Freezer Energy Testing with Alternative Refrigerants CFCs: Time of Transition, pp. 205-10 (Atlanta: American Society of Heating,

Refrigerating, and Air-Conditioning Engineers, June 1989)

E. A. Vineyard, J. R. Sand, W. A. Miller. Oak Ridge National Laboratory, Oak Ridge, Tenn.

151 Energy-Use Impact of Chlorofluorocarbon Alternatives

ORNLICON-273 (February 1989)

S. K. Fischer, F. A. Creswick. Oak Ridge National Laboratory, Oak Ridge, Tenn. 
152 Dynamic Characteristics Concerned in the Design of a Free-Piston Stirling Engine/Magnetic Coupling/Compressor

Proceedings of the 24th Intersociety Energy Conversion Engineering Conference, Washington, D.C., August 1989 5, pp. 2219-23 (1989)

G. Chen. Sunpower, Inc., Athens, Ohio

153 System Design and Performance Prediction of a Free-Piston Stirling Engine/Magnetic Coupling/Compressor Assembly in a Gas Residential Heat Pump

Advances in Heat Pumps 1989, AES 7/HTD 125, pp. 81-86 (New York: American

Society of Mechanical Engineers, 1989)

G. Chen, W. T. Beale. Sunpower, Inc., Athens, Ohio

154 Magnetically Linked Free-Piston Stirling-Refrigerant Compressor Heat Pump

Analysis and Applications of Heat Pumps, AES 8/SED 6, pp. 57-60 (New York:

American Society of Mechanical Engineers, 1989)

G. Chen, W. T. Beale. Sunpower, Inc., Athens, Ohio

155 Heat Transfer of Buried Pipe for Heat Pump Application

Advances in Heat Pumps-1989 AES 7/HTD 125, pp. 23-29 (New York: American

Society of Mechanical Engineers, 1989)

V. C. Mei. Oak Ridge National Laboratory, Oak Ridge, Tenn.

156 Motor Current Signature Analysis A Potential Diagnostic for Air Conditioners

ASHRAE Transactions 95(1), pp. 312-17 (Atlanta: American Society of Heating,

Refrigerating, and Air-Conditioning Engineers, 1989)

W. A. Miller, H. D. Haynes, F. P. Griffin, W. P. Levins, M. A. Karnitz. Oak Ridge National

Laboratory, Oak Ridge, Tenn.

157 Comparison of Thermoelectric and Vapor Cycle Technologies for Groundwater Heat Pump Application

ASME Journal of Solar Energy Engineering 111, pp. 353-57 (1989)

V. C. Mei, F. C. Chen. Oak Ridge National Laboratory, Oak Ridge, Tenn.

B. Mathiprakasam. Midwest Research Institute, Kansas City, Mo.

158 Advanced Evacuated Thermal Insulations: The State of the Art Thermal Insulation 12, pp. 183-208 (1989)

H. A. Fine. University of Kentucky, Lexington, Ky. 


\section{BUILDING THERMAL ENVELOPE SYSTEMS AND MATERIALS}

159 Thermal Resistance of Attic Loose-Fill Insulations Decreases Under Simulated Winter Conditions ORNL/M-3253 (May 1994)

R. S. Graves, K. E. Wilkes, D. L. McElroy. Oak Ridge National Laboratory, Oak Ridge, Tenn.

160 A Guidebook for Insulated Low-Slope Roof Systems Oak Ridge National Laboratory (February 1994)

Intemational Energy Agency, Buildings and Community Systems Committee, Annex 19 on Low-Slope Roof Systems

161 Flood Damage. Guidelines for Restoring Your Home

Oak Ridge National Laboratory (Spring 1994)

162 Evaluation of a Commercial, Computer-Operated Heat Flow Meter Apparatus

Rev. Sci. Instrum. 64(7), pp. 1961-70 (July 1993)

R. S. Graves, D. L. McElroy, T. G. Kollie. Oak Ridge National Laboratory, Oak Ridge, Tenn.

163 The Technical Viability of Alternative Blowing Agents in Polyisocyanurate Roof Insulation: A Cooperative Industry/Government Project ORNL/CON-367 (June 1993)

J. E. Christian, G. E. Courville, A. O. Desjarlais, R. S. Graves, R. L. Linkous, D. L. McElroy, F. J. Weaver, R. L. Wendt, D. W. Yarbrough. Oak Ridge National Laboratory, Oak Ridge, Tenn.

164 The Impact of Climate on the Drying Times of a Wetted Low-Sloped Roof System J. Thermal Insul. and BIdg. Envs. 16, pp. 234-45 (January 1993)

A. O. Desjarlais, D. M. Kyle, J. E. Christian. Oak Ridge National Laboratory, Oak Ridge, Tenn.

165 Roof System Effects on In-situ Thermal Performance of HCFC Polyisocyanurate Insulation

Polyurethanes 92: Proceedings of the SPI 34th Annual Technical Marketing Conference, New Orleans, October 20-25, 1992, pp. 400-409 (New York: Society of the Plastics Institute, 1993)

R. S. Graves, D. W. Yarbrough, D. L. McElroy, F. J. Weaver. Oak Ridge National Laboratory, Oak Ridge, Tenn.

166 Thermal Performance of Clean Horizontal Radiant Barriers Under Winter Conditions: Laboratory Measurements and Mathematical Modeling ASHRAE Trans 99(1), pp. 603-13 (Atlanta: American Society of Heating, Ventilating, and Air-conditioning Engineers, 1993)

K. E. Wilkes, P. W. Childs. Oak Ridge National Laboratory, Oak Ridge, Tenn.

167 Use of Radiation Control Coatings to Reduce Building Air-Conditioning Loads Energy Sources 15(1), p. 59 (1993)

D. W. Yarbrough. Oak Ridge National Laboratory, Oak Ridge, Tenn.

R. W. Anderson. Robert W. Anderson and Associates, Inc., Boulder City, Nev. 
168 Gauge for Nondestructive Measurement of the Internal Pressure in Powder-filled Evacuated Panel Superinsulation

Rev. Sci. Instrum. 63(12), pp. 5774-79 (December 1992)

T. G. Kollie, L. S. Thacker. Oak Ridge National Laboratory, Oak Ridge, Tenn.

169 Literature Review: Heat Transfer Through Two-Phase Insulation Systems Consisting of Powders in a Continuous Gas Phase

ORNLM-2426 (December 1992)

D. W. Yarbrough. Oak Ridge National Laboratory, Oak Ridge, Tenn.

170 Moisture Effects in Low-Slope Roofs: Drying Rates After Water Addition with Various Vapor Retarders

ORNL/CON-308 (October 1992)

C. R. Pedersen. Danish Building Research Institute, Denmark

T. W. Petrie. Marquette University, Milwaukee, Wis.

G. E. Courville, A. O. Desjarlais, P. W. Childs, K. E. Wilkes. Oak Ridge National

Laboratory, Oak Ridge, Tenn.

171 A Study of Changes in Foundation Insulation Levels in the United States ORNL/CON-351 (October 1992)

J. E. Christian. Oak Ridge National Laboratory, Oak Ridge, Tenn.

M. K. Voss. St. Mary's College, Winona, Minn.

172 Numerical Analysis of Heat Transfer by Conduction and Natural Convection in Loose-Fill Fiberglass Insulation-Effects of Convection on Thermal Performance

ORNL/CON-338 (April 1992)

A. A. Delmas, K. E. Wilkes. Oak Ridge National Laboratory, Oak Ridge, Tenn.

173 Preliminary Evaluation of Radiation Control Coatings for Energy Conservation in Buildings

ORNL/Sub/89-SE791/1 (February 1992)

R. W. Anderson. Robert W. Anderson and Associates, Inc., Boulder City, Nev.

174 The Effect of Compression on the Material R-Value of Fiberglass Batt Insulation

J. Thermal Insul. 15 (January 1992)

R. S. Graves, D. W. Yarbrough. Oak Ridge National Laboratory, Oak Ridge, Tenn.

175 A Shape Factor Method for Computing Heating Loads from Building Slabon-Grade Foundations

pp. 166-75, Thermal Performance of the Exterior Envelopes of Buildings $V$,

Proceedings of the ASHRAE/DOE/BTECC Conference, December 7-10, 1992,

Clearwater Beach, Florida (Atlanta: American Society of Heating, Refrigerating, and Air-

conditioning Engineers, 1992)

W. W. Rust. Oak Ridge Associated Universities, Oak Ridge, Tenn.

J. E. Christian. Oak Ridge National Laboratory, Oak Ridge, Tenn.

176 Thermal Performance of Fiberglass and Cellulose Attic Insulations pp. 357-67, Thermal Performance of the Exterior Envelopes of Buildings $V$, Proceedings of the ASHRAE/DOE/BTECC Conference, December 7-10, 1992,

Clearwater Beach, Florida (Atlanta: American Society of Heating, Refrigerating, and Airconditioning Engineers, 1992)

K. E. Wilkes, P. W. Childs. Oak Ridge National Laboratory, Oak Ridge, Tenn. 
177 In-Situ Thermal Performance of APP Modified Bitumen Roof Membranes Coated with Reflective Coatings

pp. 420-28, Thermal Performance of the Exterior Envelopes of Buildings $V$,

Proceedings of the ASHRAE/DOE/BTECC Conference, December 7-10, 1992,

Clearwater Beach, Florida (Atlanta: American Society of Heating, Refrigerating, and Airconditioning Engineers, 1992)

J. D. Carlson, T. L. Smith. National Roofing Contractors Association, Rosemont, III.

J. E. Christian. Oak Ridge National Laboratory, Oak Ridge, Tenn.

178 Energy Efficient Residential Building Foundations Enhance Indoor Air Quality

ASHRAE Journal 33(11), pp. 36-41 (November 1991)

J. E. Christian. Oak Ridge National Laboratory, Oak Ridge, Tenn.

179 Moisture Control Handbook: New, Low-rise, Residential Construction ORNL/Sub/89-SD350/1 (October 1991)

J. Lstiburek. Building Science Corp., Chestnut Hill, Mass.

J. Carmody. Underground Space Center, University of Minnesota, Minneapolis, Minn.

180 Corrosiveness of Wet Residential Building Thermal Insulation Mechanisms and Evaluation of Electrochemical Methods for Assessing Corrosion Behavior ORNL/Sub/90-SF204/1 (October 1991)

E. E. Stansbury. Consultant to Oak Ridge National Laboratory, Oak Ridge, Tenn.

181 A Round Robin Evaluation of the Corrosiveness of Wet Residential Insulation by Electrochemical Measurements

ORNL/Sub/90-SF204/2 (October 1991)

E. E. Stansbury. Consultant to Oak Ridge National Laboratory, Oak Ridge, Tenn.

182 Laboratory Tests Results on the Thermal Resistance of Polyisocyanurate Foamboard Insulation Blown With CFC-11 Substitutes-A Cooperative Industry/Government Project

ORNL/TM-11645 (September 1991)

D. L. McElroy, R. S. Graves, D. W. Yarbrough, F. J. Weaver. Oak Ridge National

Laboratory, Oak Ridge, Tenn.

183 A Review of Vacuum Insulation Research and Development in the Building Materials Group of the Oak Ridge National Laboratory ORNLTM-11703 (September 1991)

T. G. Kollie, D. L. McElroy, R. S. Graves, F. J. Weaver. Oak Ridge National Laboratory, Oak Ridge, Tenn.

H. A. Fine. University of Kentucky, Lexington, Ky.

K. W. Childs. Martin Marietta Energy Systems, Inc., Oak Ridge, Tenn.

184 Interlaboratory Comparison of Four Heat Flow Meter Apparatuses on Planed Polyisocyanurate Boards Foamed with CFC-11 ORNL/TM-11720 (June 1991)

R. S. Graves, D. L. McElroy. Oak Ridge National Laboratory, Oak Ridge, Tenn.

R. G. Miller. Jim Walter Research Corp., St. Petersburg, Fla.

D. W. Yarbrough. Tennessee Technological University, Cookeville, Tenn.

R. R. Zarr. National Institute of Standards and Technology, Gaithersburg, Md.

185 Technics: Under Steep Roofing

Progressive Architecture, pp. 54-56 (May 1991)

J. E. Christian. Oak Ridge National Laboratory, Oak Ridge, Tenn. 
186 Builder's Foundation Handbook

ORNL/CON-295 (May 1991)

J. Carmody. Underground Space Center, University of Minnesota, Minneapolis, Minn.

J. Christian. Oak Ridge National Laboratory, Oak Ridge, Tenn.

K. Labs. Undercurrent Design Research, New Haven, Conn.

187 Thermal Properties of Polyisocyanurate Foam Board Insulation Blown With CFC-11 Substitutes

Proc. Third International Symposium on Roofing Technology, Montreal, Canada, April 17-19, 1991, pp. 133-42 (Rosemont, III.: National Roofing Contractors Association, April 1991)

D. L. McElroy, G. E. Courville, J. E. Christian, R. L. Linkous, R. S. Graves. Oak Ridge National Laboratory, Oak Ridge, Tenn.

188 Steady-State and Transient Tests Using the Unguarded Thin-Heater Apparatus (Thermophysical Properties of Building Materials) ORNLTM-11629 (March 1991)

D. L. McElroy, R. S. Graves, D. W. Yarbrough. Oak Ridge National Laboratory, Oak Ridge, Tenn.

H. A. Fine. University of Kentucky, Lexington, Ky.

189 Thermal Performance of HCFC-22 Blown Extruded Polystyrene Insulation Insulation Materials: Testing and Applications, 2nd Volume, ASTM STP 1116, ed. R. S. Graves and D. C. Wysocki, pp. 214-28 (Philadelphia: American Society for Testing and Materials, 1991)

D. W. Yarbrough, R. S. Graves, J. E. Christian. Oak Ridge National Laboratory, Oak Ridge, Tenn.

190 Thermal Measurement of In-situ and Thin-Specimen Aging of Experimental Polyisocyanurate Roof Insulation Foamed With Alternative Blowing Agents

Insulation Materials: Testing and Applications, 2nd Volume, ASTM STP 1116, ed. R. S. Graves and D. C. Wysocki, pp. 142-66 (Philadelphia: American Society for Testing and Materials, 1991)

J. E. Christian, G. E. Courville, R. S. Graves, R. L. Linkous, D. L. McElroy, F. J. Weaver,

D. W. Yarbrough. Oak Ridge National Laboratory, Oak Ridge, Tenn.

191 ASHRAE Standard 90.2 Envelope Load Factors and Trade-off Procedures

ASHRAE Transactions 97(2), pp. 928-40 (1991)

M. F. McBride. Owens-Corning Fiberglas, Granville, Ohio

B. A. Wilcox. Berkeley Solar Group, Oakland, Calif.

J. E. Christian. Oak Ridge National Laboratory, Oak Ridge, Tenn.

192 Thermal Mass Credits Relating to Building Envelope Energy Standards

ASHRAE Transactions 97(2), pp. 941-51 (1991)

J. E. Christian. Oak Ridge National Laboratory, Oak Ridge, Tenn.

193 ORNL's Search for Roof Insulation CFC Alternatives

The Construction Specifier 43(11) (November 1990)

J. E. Christian. Oak Ridge National Laboratory, Oak Ridge, Tenn. 
194 Assessment of the Energy Conservation Potential of Active (Variable Thermal Resistance and Switchable Absorptance) Building Thermal Insulation Systems ORNL/TM-11425 (June 1990)

H. A. Fine. University of Kentucky, Lexington, Ky.

D. L. McElroy. Oak Ridge National Laboratory, Oak Ridge, Tenn.

195 Fabrication, Evaluation, and Application of Evacuated Panel Insulation (EPI) to Portable Coolers ORNL/Sub/88-SD731/1 (March 1990)

R. W. Barito, M. O. Barito. R. W. Barito \& Associates, Louisville, Ky.

T. G. Kollie, D. L. McElroy, F. J. Weaver, S. H. Werst, W. Chu. Oak Ridge National Laboratory, Oak Ridge, Tenn.

K. W. Childs. Martin Marietta Energy Systems, Inc., Oak Ridge, Tenn.

H. A. Fine. Consultant to Oak Ridge National Laboratory, Oak Ridge, Tenn.

H. L. Landrum, Jr. Igloo Products Corp., Houston, Texas

196 Chlorofluorocarbon (CFC) Technologies Review of Foamed-Board Insulation for Buildings

ORNLTM-11291 (March 1990)

D. L. McElroy. Oak Ridge National Laboratory, Oak Ridge, Tenn.

M. P. Scofield. U.S. Department of Energy, Office of Conservation and Renewable Energy, Washington, D.C.

197 Research and Development Data to Define the Thermal Performance of Reflective Materials Used to Conserve Energy In Bullding Applications ORNLSub/88-SA835/1 (March 1990)

A. O. Desjarlais, R. P. Tye. Thermatest Division of Holometrix, Inc., Cambridge, Mass.

198 Proceedings of the Roof Wind Uplift Testing Workshop, Oak Ridge, Tennessee, November 8-9, 1989

CONF-891173 (February 1990)

G. E. Courville, comp.; P. S. Gillis, ed. Oak Ridge National Laboratory, Oak Ridge, Tenn.

199 Thermal Resistance of Fine Powders at Atmospheric Pressure and Under Vacuum

Insulation Materials, Testing, and Applications, ed. D. L. McElroy and J. F. Kimpflen, ASTM STP 1030, pp. 52-65 (Philadelphia, Pa.: American Society for Testing and Materials, 1990)

D. L. McElroy, F. J. Weaver, D. W. Yarbrough, R. S. Graves. Oak Ridge National Laboratory, Oak Ridge, Tenn.

200 Modeling of Thermal Resistance Test Configurations That Use Thin Heaters

Insulation Materials, Testing, and Applications, ed. D. L. McElroy and J. F. Kimpflen, ASTM STP 1030, pp. 525-36 (Philadelphia, Pa.: American Society for Testing and Materials, 1990)

D. W. Yarbrough, D. L. McElroy, R. S. Graves. Oak Ridge National Laboratory, Oak Ridge, Tenn.

201 The Most Needed Building Foundations Research Products

Proceedings of Symposium on Insulation Materials, Testing, and Applications, Bal Harbor, Fla., December 7-9, 1987, STP 1030, pp. 655-62 (Philadelphia: American Society for Testing and Materials, 1990)

J. E. Christian. Oak Ridge National Laboratory, Oak Ridge, Tenn. 
202 An In Situ Evaluation of the Settling of Loose-Fill Rock Wool Insulation in the Attics of Two Manufactured Home Units

Proceedings of Symposium on Insulation Materials, Testing, and Applications, Bal Harbor, Fla., December 7-9, 1987, STP 1030, pp. 237-43 (Philadelphia: American Society for Testing and Materials, 1990)

R. S. Graves, D. W. Yarbrough. Oak Ridge National Laboratory, Oak Ridge, Tenn.

203 Evaluation of a Commercial, Portable, Ambient-Temperature Emissometer Rev. Sci. Instrum. 61, pp. 1509-17 (1990)

T. G. Kollie, F. J. Weaver, D. L. McElroy. Oak Ridge National Laboratory, Oak Ridge, Tenn.

204 Buildings Energy Research: ORNL/CON-292 (December 1989)

\section{A Bibliography Update}

R. S. Weaver, L. F. Goins, P. M. Love. Oak Ridge National Laboratory, Oak Ridge, Tenn.

205 Catalog of Thermal Bridges in Commercial and Multi-Family Residential Construction

ORNL/Sub/88-SA407/1 (December 1989)

A. N. Tuluca, D. M. Evans, K. Kuman, M. Krarti. Steven Winter Associates, Inc., New York, N.Y.

K. W. Childs. Martin Marietta Energy Systems, Inc., Oak Ridge, Tenn.

G. E. Courville. Oak Ridge National Laboratory, Oak Ridge, Tenn.

T. Vonier. Thomas Vonier Associates, Inc., Washington, D.C.

R. Tye. Holometrix, Inc., Cambridge, Mass.

206 Measurement of Thermal Drift in Foam Insulation ORNL/TM-11290 (October 1989)

G. E. Courville, P. W. Childs. Oak Ridge National Laboratory, Oak Ridge, Tenn.

207 Overview of the Applicability of Electrochemical Methods to Evaluation of the Corrosiveness of Residential Building Thermal Insulations with Proposed Cooperative Test Program

ORNL/Sub/87-B8240/1 (September 1989)

E. E. Stansbury. Consultant to Oak Ridge National Laboratory, Oak Ridge, Tenn.

208 U.S. Building Materials Industry: R\&D Barriers Assessment

ORNL/Sub/88-SB964/1 (September 1989)

F. H. Klareich, J. C. Frank. RCG/Hagler, Bailly, Inc., Washington, D.C.

209 Guide for Estimating Differences in Building Heating and Cooling Energy Due to Changes in Solar Reflectance of a Low-Sloped Roof

ORNL-6527 (August 1989)

E. I. Griggs. Tennessee Technological University, Cookeville, Tenn.

T. R. Sharp, J. M. MacDonald. Oak Ridge National Laboratory, Oak Ridge, Tenn.

210 Heat and Mass Transfer Through Porous Media

ORNL/Sub/85-27486/2 (August 1989)

S. Motakef, L. R. Glicksman. Massachusetts Institute of Technology, Cambridge, Mass.

211 Model for Roof Thermal Performance

ORNLCON-274 (July 1989)

K. E. Wilkes. Oak Ridge National Laboratory, Oak Ridge, Tenn. 
212 International Symposium Proceedings on Mathematical Modeling of Roof Systems, Oak Ridge, Tennessee, September 15-16, 1988 CONF-8809314 (May 1989)

G. E. Courville, ed. Oak Ridge National Laboratory, Oak Ridge, Tenn.

213 The Roof Research Center - A National User Facility for Thermal Performance and Durability of Roofing Systems. Users Manual. ORNLM-329/2 (April 1989)

G. E. Counville. Oak Ridge National Laboratory, Oak Ridge, Tenn.

214 Design Description of the Large Scale Climate Simulator ORNLTM-10675 (March 1989)

W. R. Huntley. Oak Ridge National Laboratory, Oak Ridge, Tenn.

215 Changes in the Heating and Cooling Energy Use in Buildings Due to Lowering the Surface Solar Absorptance of Roofs ORNLTM-10339 (February 1989)

E. I. Griggs. Tennessee Technological University, Cookeville, Tenn.

G. E. Counille. Oak Ridge National Laboratory, Oak Ridge, Tenn.

216 An Experimental Study of Stabilized Cellulosic Insulation Installed in Four Attic Sections of Manufactured Homes

ORNL/TM-10775 (January 1989)

R. S. Graves, D. W. Yarbrough. Oak Ridge National Laboratory, Oak Ridge, Tenn.

217 ZIP-The ZIP-Code Insulation Program (Version 1.0). Economic Insulation Levels for New and Existing Houses by Three-Digit ZIP Code. Users Guide and Reference Manual ORNLTM-11009* (January 1989)

S. R. Petersen. National Institute of Standards and Technology, Gaithersburg, Md.

218 A Capacitance Probe for Measurement of Moisture Content in Open Pore Thermal Insulations ORNL/Sub/85-27486/1 (January 1989)

S. Motakef, L. R. Glicksman. Massachusetts Institute of Technology, Cambridge, Mass.

219 The Thermal Resistance of Flat Powder-Filled Evacuated Panels Proceedings of the International Conference on Thermal Insulation, San Francisco, California, February 27-March 1, 1989, 5, pp. 20-34 (Sunnyvale, Calif.: Product Safety Corporation, 1989)

R. S. Graves, D. W. Yarbrough, D. L. McElroy. Oak Ridge National Laboratory, Oak Ridge, Tenn.

220 Testing of Loose-Fill Cellulosic Insulation Taken From Residential Attics in Four Cities

Proceedings of the Second Califomia Thermal Insulation Conference, Sacramento, California September 18-20, 1989, ed. S. A. Siddiqui, pp. 86-97 (North Highlights, Calif.: Bureau of Home Furnishings and Thermal Insulation, 1989)

R. S. Graves, D. W. Yarbrough. Oak Ridge National Laboratory, Oak Ridge, Tenn.

\footnotetext{
*Also available as report no. NISTIR 88-3801 from the National Institute of Standards and Technology, Gaithersburg, Maryland 20899.
} 
221 Proceedings: Thermal Performance of the Exterior Envelopes of Buildings IV, December 4-7, 1989, Orlando, Florida

Atlanta: American Society of Heating, Refrigerating, and Air-Conditioning Engineers, 1989

P. M. Love, G. E. Courville, eds. Oak Ridge National Laboratory, Oak Ridge, Tenn.

222 Proceedings: 1986 International Daylighting Conference, November 47, 1986, Long Beach, California

Atlanta: American Society of Heating, Refrigerating, and Air-Conditioning Engineers, 1989

E. Bales, ed. New Jersey Institute of Technology, Newark, N.J.

223 Radon Mitigation in New Construction

Encyclopedia of Architecture: Design, Engineering, and Construction 4, pp. 147-55

(New York: John Wiley \& Sons, Inc., 1989)

J. E. Christian. Oak Ridge National Laboratory, Oak Ridge, Tenn.

224 Techniques for In Situ Determination of Thermal Resistance of Light Weight Board Insulations

J. Heat Trans. 111, pp. 274-80 (1989)

G. E. Courville. Oak Ridge National Laboratory, Oak Ridge, Tenn.

J. V. Beck. Michigan State University, East Lansing, Mich.

225 The International Energy Agency on Low Slope Roofing Systems Int. J. Roofing Technol. 1, pp. 29-31 (1989)

G. E. Courville. Oak Ridge National Laboratory, Oak Ridge, Tenn.

226 Comparison of the Dynamic Thermal Performance of Insulated Roof Systems

Proceedings of the Ninth Conference on Roofing Technology, Gaithersburg, Maryland, May 4-5, 1989, pp. 50-55 (Chicago, III.: National Roofing Contractors Association, 1989) G. E. Courville, P. W. Childs. Oak Ridge National Laboratory, Oak Ridge, Tenn.

P. H. Shipp. USG Corp., Libertyville, III.

T. W. Petrie. Marquette University, Milwaukee, Wis. 


\section{DISTRICT HEATING}

227 The National Action Plan for District Heating, Cooling and Cogeneration. An Industry-Government Partnership

National Planning Committee for District Heating, Cooling and Cogeneration, March $1992^{*}$

*Available from M. A. Broders, Oak Ridge National Laboratory, P. O. Box 2008, Oak Ridge TN 37831-6070. 


\section{RESIDENTIAL AND COMMERCIAL CONSERVATION PROGRAM}

228 Direct Installation of Lighting Measures in Small Nonresidential Buildings Proceedings ACEEE 1990 Summer Study on Energy Efficiency in Buildings, Volume 8: Utility Programs, pp. 8.37-8.42 (Washington, D.C.: American Council for an EnergyEfficient Economy, 1990)

M. B. Gettings, J. M. MacDonald. Oak Ridge National Laboratory, Oak Ridge, Tenn.

229 Life After RCs: Is There a Future for Audit and Other Residential Conservation Programs? Home Energy 7(3), pp. 24-28 (1990)

R. Vories. Infinite Energy, Denver, Colo.

D. L. White. Oak Ridge National Laboratory, Oak Ridge, Tenn.

230 Expansion of Electric Utility DSM Services to Small Businesses ORNL/CON-293 (September 1989)

M. B. Gettings, J. M. MacDonald. Oak Ridge National Laboratory, Oak Ridge, Tenn. 



\section{WEATHERIZATION ASSISTANCE PROGRAM}

\section{Ten Highly Effective Weatherization Programs}

Home Energy 11(3), p. 23 (May 1994)

M. A. Brown, L. G. Berry. Oak Ridge National Laboratory, Oak Ridge, Tenn.

232 Weatherization Works: An Interim Report of the National Weatherization Evaluation

ORNLLON-373 (November 1993)

M. A. Brown, L. G. Berry. Oak Ridge National Laboratory, Oak Ridge, Tenn.

L. F. Kinney. Synertech Systems Corp., Syracuse, N. Y.

233 Keys to Success: Ten Case Studies of Effective Weatherization Programs

ORNL/CON-328 (November 1993)

M. A. Brown, L. G. Berry, J. O. Kolb, D. L. White. Oak Ridge National Laboratory, Oak

Ridge, Tenn.

L. F. Kinney, T. C. Wilson. Synertech Systems Corp., Syracuse, N. Y.

234 Weatherization Assistance: The Single-Family Study Home Energy 10(5), p. 11 (September 1993)

M. A. Brown, L. G. Berry. Oak Ridge National Laboratory, Oak Ridge, Tenn.

235 National Impacts of the Weatherization Assistance Program in SingleFamily and Small Multifamily Dwellings

ORNL/CON-326 (May 1993)

M. A. Brown, L. G. Berry. Oak Ridge National Laboratory, Oak Ridge, Tenn.

R. A. Balzer, E. Faby. Consultants to Oak Ridge National Laboratory, Oak Ridge, Tenn.

236 Description of the Weatherization Assistance Program in Larger Multifamily Buildings for Program Year 1989

ORNL/CON-329 (April 1993)

J. M. MacDonald. Oak Ridge National Laboratory, Oak Ridge, Tenn.

237 The Reach of Low-Income Weatherization Assistance

Home Energy 10(4), pp. 21-25 (1993)

M. Power. National Community Action Foundation, Washington, D. C.

M. A. Brown. Oak Ridge National Laboratory, Oak Ridge, Tenn.

238 A Status Report on the National Weatherization Evaluation pp. 7.27-7.29, Proceedings ACEEE 1992 Summer Study on Energy Efficiency in Buildings (Washington, D. C.: American Council for an Energy-Efficient Economy, 1992) M. A. Brown. Oak Ridge National Laboratory, Oak Ridge, Tenn.

D. A. Beschen. U.S. Department of Energy, Office of Energy Efficiency and Renewable Energy, Washington, D. C.

239 Scope of the Weatherization Assistance Program: The Weatherized Population and The Resource Base

ORNL/CON-325 (May 1992)

M. Power, J. F. Eisenberg, E. Michels. Economic Opportunity Research Institute, Washington, D.C.

M. J. Witherspoon. National Association for State Community Service Programs, Washington, D.C.

M. A. Brown. Oak Ridge National Laboratory, Oak Ridge, Tenn. 
240 Characterization of the Weatherization Assistance Program Network ORNL/CON-324 (February 1992)

P. E. Mihlmester, W. C. Koehler, Jr., M. A. Beyer. Aspen Systems Corporation, Oak Ridge, Tenn.

M. A. Brown. Oak Ridge National Laboratory, Oak Ridge, Tenn.

D. A. Beschen, Jr. Weatherization Assistance Program, U.S. Department of Energy, Washington, D.C.

241 Experimental Plan for the Fuel-Oil Study

ORNLTM-11668/V2 (January 1992)

M. P. Ternes, W. P. Levins, M. A. Brown. Oak Ridge National Laboratory, Oak Ridge, Tenn.

242 Interaction of Heating and Cooling Energy Conservation Envelope

Measures with Mechanical System Retrofits

pp. 687-88, Thermal Performance of the Exterior Envelopes of Buildings $V$,

Proceedings of the ASHRAE/DOE/BTECC Conference, December 7-10, 1992,

Clearwater Beach, Florida (Atlanta, Ga.: American Society of Heating, Ventilating, and Air-

Conditioning Engineers, 1992)

M. B. Gettings. Oak Ridge National Laboratory, Oak Ridge, Tenn.

243 Evaluation Plan for the Weatherization Assistance Program

ORNL/TM-11668/N1 (August 1991)

D. A. Beschen. Weatherization Assistance Program, U.S. Department of Energy,

Washington, D.C.

M. A. Brown. Oak Ridge National Laboratory, Oak Ridge, Tenn.

244 Experimental Plan for the Single-Family Study

ORNLTM-11668/V3 (September 1991)

L. G. Berry, M. A. Brown, T. Wright, D. L. White. Oak Ridge National Laboratory, Oak

Ridge, Tenn.

245 Assessment of Weatherization Assistance Program Needs for Improved Residential Measure Selection Techniques

ORNL/CON-316 (February 1991)

M. B. Gettings, J. O. Kolb. Oak Ridge National Laboratory, Oak Ridge, Tenn.

246 Measuring the Effects of Conservation Program Special Services: Client Education, Fuel Assistance, and Other Indirect Outcomes

Affordable Comfort V, 5 (Harrisburg: Pennsylvania Energy Office, 1991)

D. L. White. Oak Ridge National Laboratory, Oak Ridge, Tenn.

247 The North Carolina Field Test: Experimental Plan

ORNL/TM-11339 (August 1990)

T. R. Sharp, M. P. Ternes. Oak Ridge National Laboratory, Oak Ridge, Tenn.

248 Implementation of Blower Door and New Client Selection Concepts Into the lowa Weatherization Assistance Program: Experimental Plan ORNL/CON-282 (August 1989)

M. P. Ternes, H. L. Hwang. Oak Ridge National Laboratory, Oak Ridge, Tenn. 


\section{EXISTING BUILDINGS RESEARCH PROGRAM}

249 Cooling Benefits from Exterior Masonry Wall Insulation Home Energy 11(2), p. 33 (March 1994)

M. P. Ternes, K. E. Wilkes, H. A. McLain. Oak Ridge National Laboratory, Oak Ridge, Tenn.

250 Affordable Cooling with Window Air Conditioners Home Energy 10(4), p. 23 (July 1993)

M. P. Ternes. Oak Ridge National Laboratory, Oak Ridge, Tenn.

251 Research Update, Existing Buildings Research, 1989-1991 ORNL/CON-333 (February 1993)

J. M. MacDonald, M. P. Temes, W. R. Mixon, T. R. Sharp, J. O. Kolb, K. E. Wilkes. Oak Ridge National Laboratory, Oak Ridge, Tenn.

R. C. Diamond. Lawrence Berkeley Laboratory, Berkeley, Calif.

R. Judkoff. National Renewable Energy Laboratory, Golden, Colo.

R. P. Mazzucchi. Pacific Northwest Laboratories, Richland, Wash.

252 The Oklahoma Field Test: Air-Conditioning Electricity Savings from Standard Energy Conservation Measures, Radiant Barriers, and HighEfficiency Window Air Conditioners

ORNL/CON-317 (August 1992)

M. P. Ternes, W. P. Levins. Oak Ridge National Laboratory, Oak Ridge, Tenn.

253 Modeling Study of the Cooling Season Performance of Exterior Wall Insulation

pp. 655-67, Thermal Performance of the Exterior Envelopes of Buildings $V$,

Proceedings of the ASHRAE/DOE/BTECC Conference, December 7-10, 1992,

Clearwater Beach, Florida (Atlanta, Ga.: American Society of Heating, Refrigerating, and

Air-conditioning Engineers, 1992)

H. A. McLain. Oak Ridge National Laboratory, Oak Ridge, Tenn.

254 Energy Savings and Interactions from Retrofit Measures in Small Commercial Buildings in Boston

pp. 31-38, Thermal Performance of the Exterior Envelopes of Buildings $V$, Proceedings of the ASHRAE/DOE/BTECC Conference, December 7-10, 1992, Clearwater Beach, Florida (Atlanta, Ga.: American Society of Heating, Refrigerating, and Air-conditioning Engineers, 1992)

T. R. Sharp, J. M. MacDonald. Oak Ridge National Laboratory, Oak Ridge, Tenn.

255 Monitoring and Evaluation of Foundation Insulation Retrofits in SingleFamily Detached Houses in St. Paul and Minneapolis, Minnesota. Final Report

ORNL/Sub/86-SA711/N (October 1991)

M. J. Hewett. Center for Energy and the Urban Environment, Minneapolis, Minn.

G. D. Nelson. Gary Nelson and Associates, Minneapolis, Minn.

M. T. Noble. Natural Resources Corp., Minneapolis, Minn.

D. A. Robinson. Robinson Technical Services, St. Paul, Minn.

L. S. Shen, L. F. Goldberg. University of Minnesota, Minneapolis, Minn. 
256 Monitoring and Evaluation of Replacing Low-Efficiency Air Conditioners with High-Efficiency Air Conditioners in Single-Family Detached Houses in Austin, Texas

ORNL/Sub/86-SA566/N (August 1991)

R. Burns, R. E. Hough. The Fleming Group, East Syracuse, N.Y.

257 Thermal Model of Attic Systems with Radiant Barriers

ORNL/CON-262 (July 1991)

K. E. Wilkes. Oak Ridge National Laboratory, Oak Ridge, Tenn.

258 Radiant Barrier Attic Fact Sheet

DOE/CE-0335P, ORNL/M-1937 (June 1991)

K. E. Wilkes. Oak Ridge National Laboratory, Oak Ridge, Tenn.

259 Analysis of Annual Thermal and Moisture Performance of Radiant Barrier Systems

ORNLCON-319 (April 1991)

K. E. Wilkes. Oak Ridge National Laboratory, Oak Ridge, Tenn.

260 The National Fuel End-Use Efficiency Field Test: Energy Savings and Performance of an Improved Energy Conservation Measure Selection Technique

ORNL/CON-303 (March 1991)

M. P. Ternes, P. S. Hu, L. S. Williams. Oak Ridge National Laboratory, Oak Ridge, Tenn.

P. Goewey. National Fuel Gas Distribution Corp., Buffalo, N.Y.

261 Measured Space-Cooling Electricity Savings from Standard Energy Conservation Measures, Radiant Barriers, and High-Efficiency Window Air Conditioners

Proceedings of the ACEEE 1990 Summer Study on Energy Efficiency in Buildings 9, pp. 299-308 (Washington, D.C.: American Council for an Energy-Efficient Economy, August 1990)

M. P. Ternes, W. P. Levins. Oak Ridge National Laboratory, Oak Ridge, Tenn.

262 Analysis of Annual Energy Savings Due to Radiant Barriers Proceedings of the ACEEE 1990 Summer Study on Energy Efficiency in Buildings 1, pp. 235-45 (Washington, D.C.: American Council for an Energy-Efficient Economy, August 1990)

K. E. Wilkes. Oak Ridge National Laboratory, Oak Ridge, Tenn.

263 Measurement of Energy Performance in a Small Bank Building ORNLCON-297 (April 1990)

T. R. Sharp, J. M. MacDonald. Oak Ridge National Laboratory, Oak Ridge, Tenn.

264 Cooling Season Energy Measurements of Dust and Ventilation Effects on Radiant Barriers

ORNL/CON-271 (March 1990)

W. P. Levins, M. A. Karnitz. Oak Ridge National Laboratory, Oak Ridge, Tenn.

J. A. Hall. Tennessee Valley Authority, Knoxville, Tenn.

265 Power Generation from Waste Incineration

Energy Engineering 87(3), pp. 49-62 (1990)

J. O. Kolb, K. E. Wilkes. Oak Ridge National Laboratory, Oak Ridge, Tenn. 
266 Energy Savings and Performance of an Improved Energy Efficiency Measure Selection Technique

ASHRAE Transactions 96(Pt. 2) (Atlanta, Ga.: American Society of Heating,

Refrigerating, and Air-Conditioning Engineers, 1990)

M. P. Ternes. Oak Ridge National Laboratory, Oak Ridge, Tenn.

267 A Protocol for Monitoring Energy Efficiency Improvements in Commercial and Related Buildings

ORNL/CON-291 (September 1989)

J. M. MacDonald, T. R. Sharp, M. B. Gettings. Oak Ridge National Laboratory, Oak Ridge, Tenn.

268 Protocols Are Being Developed to Guide Building Energy Monitoring Projects

ASHRAE Journal 31(6), p. 38 (June 1989)

W. R. Mixon. Oak Ridge National Laboratory, Oak Ridge, Tenn.

H. Misuriello. W. S. Fleming Associates, Washington, D.C.

269 Technology Adoption Strategy for the Existing Buildings Efficiency Research Program

ORNL/CON-286 (June 1989)

P. E. Mihlmester, J. Gonos, L. Freeman. Applied Management Sciences, Inc., Oak

Ridge, Tenn.

M. A. Brown. Oak Ridge National Laboratory, Oak Ridge, Tenn.

270 Investigation of Metered Data Analysis Methods for Commercial and Related Buildings

ORNL/CON-279 (May 1989)

J. M. MacDonald. Oak Ridge National Laboratory, Oak Ridge, Tenn.

D. M. Wasserman. Consultant to Oak Ridge National Laboratory, Oak Ridge, Tenn.

271 Moisture Measurements in Single-Family Houses with Attics Containing Radiant Barriers

ORNLCON-255 (February 1989)

W. P. Levins, M. A. Karnitz. Oak Ridge National Laboratory, Oak Ridge, Tenn.

J. A. Hall. Tennessee Valley Authority, Chattanooga, Tenn.

272 The Oklahoma Cooling Retrofit Field Test: Experimental Plan

ORNLTM-10761 (January 1989)

M. P. Ternes, P. S. Hu. Oak Ridge National Laboratory, Oak Ridge, Tenn.

273 Load Impacts of Energy Management Hardware

Proceedings of the End-Use Load Information and Application Conference for Customer and Utility Communication, Syracuse, New York, May 16-17, 1989 (Syracuse, N.Y.: The Fleming Group, 1989)

J. M. MacDonald, T. R. Sharp. Oak Ridge National Laboratory, Oak Ridge, Tenn. 



\section{CERAMIC TECHNOLOGY PROJECT}

274 Creep and Stress Rupture Behavior of an Advanced Silicon Nitride: Part I, Experimental Observations J. Am. Ceram. Soc. T7(5), p. 1217-27 (May 1994)

M. N. Menon, H. T. Fang, D. C. Wu. AlliedSignal, Inc., Phoenix, Ariz.

M. G. Jenkins. University of Washington, Seattle, Wash.

M. K. Ferber, K. L. More, C. R. Hubbard, T. A. Nolan. Oak Ridge National Laboratory, Oak

Ridge, Tenn.

275 Creep and Stress Rupture Behavior of an Advanced Silicon Nitride: Part II, Creep Rate Behavior

J. Am. Ceram. Soc. 77(5), p. 1228-34 (May 1994)

M. N. Menon, H. T. Fang, D. C. Wu. AlliedSignal, Inc., Phoenix, Ariz.

M. G. Jenkins. University of Washington, Seattle, Wash.

M. K. Ferber. Oak Ridge National Laboratory, Oak Ridge, Tenn.

276 Creep and Stress Rupture Behavior of an Advanced Silicon Nitride: Part III, Stress Rupture and the Monkman-Grant Relationship

J. Am. Ceram. Soc. 77(5), p. 1235-41 (May 1994)

M. N. Menon, H. T. Fang, D. C. Wu. AlliedSignal, Inc., Phoenix, Ariz.

M. G. Jenkins. University of Washington, Seattle, Wash.

M. K. Ferber. Oak Ridge National Laboratory, Oak Ridge, Tenn.

277 Creep and Creep Rupture of an Advanced Silicon Nitride Ceramic

J. Am. Ceram. Soc. 77(4), pp. 867-74 (April 1994)

J. L. Ding. Washington State University, Pullman, Wash.

K. C. Liu, K. L. More, C. R. Brinkman. Oak Ridge National Laboratory, Oak Ridge, Tenn.

278 Effect of Relative Humidity of Repetitive Impact Behavior of Machined Silicon Nitride

J. Am. Ceram. Soc. 77(3), p. 683 (March 1994)

S. Srinivasan, P. J. Blau. Oak Ridge National Laboratory, Oak Ridge, Tenn.

279 Materials Development Program Ceramic Technology Project Bibliography (1984-1992)

ORNLM-3201 (March 1994)

S. G. Winslow. Oak Ridge National Laboratory, Oak Ridge, Tenn.

280 Ceramic Technology Project Database: September 1993 Summary Report ORNL/M-3155 (January 1994)

B. L. P. Keyes. Oak Ridge National Laboratory, Oak Ridge, Tenn.

281 Thermal Shock Behavior of Silicon Nitride Flexure Beam Specimens with Indentation Cracks

J. Am. Ceram. Soc. 77(3), pp. 835-38 (1994)

S. R. Choi, J. A. Salem. NASA Lewis Research Center, Cleveland, Ohio

282 Life Prediction Methodologies and Data for Ceramic Materials

ASTM Special Technical Publication 1201 (Philadelphia: American Society for Testing and Materials, 1994)

C. R. Brinkman, ed. Oak Ridge National Laboratory, Oak Ridge, Tenn.

S. F. Duffy, ed. NASA Lewis Research Center, Cleveland, Ohio 
283 Fracture of Silicon Nitride and Silicon Carbide at Elevated Temperatures Materials Science and Engineering A176, pp. 51-60 (1994)

S. M. Wiederhorn, B. A. Fields, B. J. Hockey. National Institute of Standards and Technology, Gaithersburg, Md.

284 Beneficial Effects of Cyclic Tensile Loading on the Fatigue Resistance of an $\mathrm{Si}_{3} \mathrm{~N}_{4}$

J. Mat. Sci. Letters 12(24), pp. 1940-44 (December 1993)

M. G. Jenkins. University of Washington, Seattle, Wash.

M. K. Ferber. Oak Ridge National Laboratory, Oak Ridge, Tenn.

C.-K. J. Lin. Oak Ridge Institute for Science and Education, Oak Ridge, Tenn.

285 Role of Oxidation in the Time-Dependent Failure Behavior of HIPed Silicon Nitride at $1370^{\circ} \mathrm{C}$

J. Am. Ceram. Soc. 76(11), p. 2919 (November 1993)

A. A. Wereszczak, K. Breder, M. K. Ferber. Oak Ridge National Laboratory, Oak Ridge, Tenn.

286 Ceramic Technology Project Semiannual Progress Report for October 1992 Through March 1993

ORNL/TM-12428 (September 1993)

D. R. Johnson. Oak Ridge National Laboratory, Oak Ridge, Tenn.

287 Application of Microwave Heating for Fabrication of Silicon Nitride Ceramics

Ceramic Engineering and Science Proceedings September-October 1993. 17th Annual

Conference on Composites and Advanced Ceramic Materials 14(9/10), pp. 74452

(Westerville, Ohio: American Ceramic Society, 1993)

T. N. Tiegs, J. O. Kiggans, K. L. Ploetz. Oak Ridge National Laboratory, Oak Ridge, Tenn.

288 Development of Improved Processing and Evaluation Methods for High Reliability Structural Ceramics for Advanced Heat Engine Applications, Phase I

ORNL/Sub/89-SB182/1 (August 1993)

V. K. Pujari, D. M. Tracey, M. R. Foley, N. I. Paille, P. J. Pelletier, L. C. Sales, C. A.

Willkens, R. L. Yeckley. Saint-Gobain'Norton Industrial Ceramics, Northboro, Mass.

289 Ceramic Technology Project Semiannual Progress Report for April 1992 Through September 1992

ORNL/TM-12363 (July 1993)

D. R. Johnson. Oak Ridge National Laboratory, Oak Ridge, Tenn.

290 Survey of Ceramic Machining in Japan

ORNL/M-2881 (July 1993)

B. P. Bandyopadhyay. University of North Dakota, Grand Forks, N. D.

P. J. Blau. Oak Ridge National Laboratory, Oak Ridge, Tenn

291 Ceramic Technology Project Data Base: September 1992 Summary

Report

ORNL/M-2775 (June 1993)

B. L. P. Keyes. Oak Ridge National Laboratory, Oak Ridge, Tenn.

292 Studies of Dynamic Contact of Ceramics and Alloys for Advanced Heat Engines

ORNL/Sub/84-00216/2 (June 1993)

P. A. Gaydos, K. F. Dufrane. Battelle Memorial Institute, Columbus, Ohio 
293 Analytical and Experimental Evaluation of Joining Silicon Nitride to Metal and Silicon Carbide to Metal for Advanced Heat Engine Applications ORNLSub/90-SB047/2 (May 1993)

S. Kang, J. H. Selverian, D. O'Neil, H. Kim, K. Kim. GTE Laboratories, Waltham, Mass.

294 Cost-Effective Ceramic Machining Highlights

ORNLM-2827 (May 1993)

P. J. Blau. Oak Ridge National Laboratory, Oak Ridge, Tenn.

295 Low-Expansion Ceramics Initiative

Proceedings of the Annual Automotive Technology Development Contractors'

Coordination Meeting 1992, Dearborn, Mich., Nov. 2-5, 1992, pp. 367-70 (Warrendale,

Pa.: Society of Automotive Engineers, May 1993)

D. P. Stinton. Oak Ridge National Laboratory, Oak Ridge, Tenn.

D. W. Richerson. Consultant to Oak Ridge National Laboratory, Oak Ridge, Tenn.

296 The Drive to Cost-Effective Structural Ceramics

Proceedings of the Annual Automotive Technology Development Contractors'

Coordination Meeting 1992, Dearborn, Mich., Nov. 2-5, 1992, pp. 353-59 (Warrendale, Pa.: Society of Automotive Engineers, May 1993)

R. B. Schulz. Office of Energy Efficiency and Renewable Energy, Department of Energy, Washington, D. C.

D. R. Johnson. Oak Ridge National Laboratory, Oak Ridge, Tenn.

297 Development of a Constitutive Model for Creep and Life Prediction of Advanced Silicon Nitride Ceramics

Proceedings of the Annual Automotive Technology Development Contractors'

Coordination Meeting 1992, Dearborn, Mich., Nov. 2-5, 1992, pp. 583-92 (Warrendale,

Pa.: Society of Automotive Engineers, May 1993)

J. L. Ding. Washington State University, Pullman, Wash.

K. C. Liu, C. R. Brinkman. Oak Ridge National Laboratory, Oak Ridge, Tenn.

298 Cost-Effective Ceramic Machining Program

Proceedings of the Annual Automotive Technology Development Contractors'

Coordination Meeting 1992, Dearborn, Mich., Nov. 2-5, 1992, pp. 361-65 (Warrendale,

Pa.: Society of Automotive Engineers, May 1993)

P. J. Blau. Oak Ridge National Laboratory, Oak Ridge, Tenn.

299 Overview of NDE Dovelopment

Proceedings of the Annual Automotive Technology Development Contractors'

Coordination Meeting 1992, Dearborn, Mich., Nov. 2-5, 1992, pp. 433-41 (Warrendale, Pa.: Society of Automotive Engineers, May 1993)

R. W. McClung. Oak Ridge National Laboratory, Oak Ridge, Tenn.

300 Processing Methodology for the Production of Reliable High Strength Silicon Nitride

Proceedings of the Annual Automotive Technology Development Contractors'

Coordination Meeting 1992, Dearborn, Mich., Nov. 2-5, 1992, pp. $433-49$ (Warrendale, Pa.: Society of Automotive Engineers, May 1993)

V. K. Pujari, D. M. Tracey, M. R. Foley, N. I. Paille, P. J. Pelletier, L. C. Sales, C. A.

Willkens, R. L. Yeckley. Saint-Gobain/Norton Industrial Ceramics, Northboro, Mass.

301 Recent Advances in the Development of HEXOLOY SX-SiC

Proceedings of the Annual Automotive Technology Development Contractors'

Coordination Meeting 1992, Dearborn, Mich., Nov. 2-5, 1992, pp. 451-63 (Warrendale,

Pa.: Society of Automotive Engineers, May 1993)

G. V. Srinivasan, S. K. Lau, R. S. Storm. The Carborundum Company, Niagara Falls, N. Y. 
302 In Situ Reinforced $\mathrm{Si}_{3} \mathrm{~N}_{4}$

Proceedings of the Annual Automotive Technology Development Contractors' Coordination Meeting 1992, Dearborn, Mich., Nov. 2-5, 1992, pp. 465-69 (Warrendale, Pa.: Society of Automotive Engineers, May 1993)

H. Yeh, J. Yamanis, C.-W. Li, J. Pollinger, E. Solidum, M. Behi. AlliedSignal, Inc., Torrance, Calif.

303 Progress in Life Prediction Methodology for Ceramic Components of Advanced Heat Engines Proceedings of the Annual Automotive Technology Development Contractors' Coordination Meeting 1992, Dearborn, Mich., Nov. 2-5, 1992, pp. 471-84 (Warrendale, Pa.: Society of Automotive Engineers, May 1993)

J. C. Wade, J. S. Cuccio, H. T. Fang, K. Seybold. AlliedSignal, Inc., Phoenix, Az.

304 Mechanical Testing of Candidate Ceramics

Proceedings of the Annual Automotive Technology Development Contractors'

Coordination Meeting 1992, Dearborn, Mich., Nov. 2-5, 1992, pp. 555-65 (Warrendale, Pa.: Society of Automotive Engineers, May 1993)

N. L. Hecht, S. M. Goodrich, L. Chuck, D. E. McCullum. University of Dayton Research Institute, Dayton, Ohio

305 Thick Thermal Barrier Coatings

Proceedings of the Annual Automotive Technology Development Contractors' Coordination Meeting 1992, Dearborn, Mich., Nov. 2-5, 1992, pp. 567-72 (Warrendale, Pa.: Society of Automotive Engineers, May 1993)

M. B. Beardsley. Caterpillar, Inc., Peoria, III.

306 Development of Wear-Resistant Ceramic Coatings for Diesel Engine Applications

Proceedings of the Annual Automotive Technology Development Contractors' Coordination Meeting 1992, Dearborn, Mich., Nov. 2-5, 1992, pp. 573-76 (Warrendale, Pa.: Society of Automotive Engineers, May 1993)

M. H. Haselkorn, F. A. Kelley. Caterpillar, Inc., Peoria, III.

307 Silicon Nitride Powders Processing in High Energy Agitation Mill Proceedings of the Annual Automotive Technology Development Contractors' Coordination Meeting 1992, Dearborn, Mich., Nov. 2-5, 1992, pp. 577-81 (Warrendale, Pa.: Society of Automotive Engineers, May 1993)

S. G. Malghan, D. B. Minor. National Institute of Standards and Technology, Gaithersburg, Md.

308 Brazing Titanium-Vapor-Coated Zirconia

Weld. Res. Suppl., pp. 165s-72s (April 1993)

M. L. Santella, J. J. Pak. Oak Ridge National Laboratory, Oak Ridge, Tenn.

309 An Ultrasonic Evaluation of Silicon Carbide Whisker-Reinforced Ceramic Composites Mater. Eval. 51(3), pp. 39195 (March 1993)

W. A. Simpson, Jr. Oak Ridge National Laboratory, Oak Ridge, Tenn.

R. W. McClung. Consultant to Oak Ridge National Laboratory, Oak Ridge, Tenn. 
310 Fracture Toughness of Advanced Ceramics at Room Temperature: A VAMAS Round Robin

Ceramic Engineering and Science Proceedings July-August 1993. 17th Annual

Conference on Composites and Advanced Ceramic Materials 14(7/8), part 1, pp. 92-100

(Westerville, Ohio: American Ceramic Society, 1993)

G. D. Quinn. National Institute of Standards and Technology, Gaithersburg, Md.

311 Fracture Toughness ( $\mathrm{K}_{/ \mathrm{C}}$ \& ywof) of a HIPed $\mathrm{Si}_{3} \mathrm{~N}_{4}$ at Elevated Temperatures

Ceramic Engineering and Science Proceedings July-August 1993. 17th Annual

Conference on Composites and Advanced Ceramic Materials 14(7/8), part 1, pp. 101-12

(Westerville, Ohio: American Ceramic Society, 1993)

A. A. Wereszczak, M. K. Ferber, R. R. Sanders. Oak Ridge National Laboratory, Oak

Ridge, Tenn.

M. G. Jenkins. University of Washington, Seattle, Wash.

P. Khandelwal. Allison Gas Turbine Division, General Motors Corp., Indianapolis, Ind.

312 Analysis of Pull-Tests for Determining the Effects of Ion Implantation on the Adhesion of Iron Films to Sapphire Substrates

J. Adhesion Sci. Tech. 7(8), p. 845 (1993)

J. E. Pawel, C. J. McHargue. Oak Ridge National Laboratory, Oak Ridge, Tenn.

313 A Mechanical Extensometer for High Temperature Tensile Testing of Ceramics

J. Test. Eval., pp. 406-13 (1993)

K. C. Liu. Oak Ridge National Laboratory, Oak Ridge, Tenn.

J. L. Ding. Washington State University, Pullman, Wash.

314 Nondestructive Testing of Ceramics for Vehicular Advanced Heat Engines

Proceedings of the Spring Conference of the American Society for Nondestructive Testing, Orlando, Fla., March 30-April 13, 1992, p. 105 (Atlanta: American Society of Mechanical Engineers, 1993)

R. W. McClung. Consultant to Oak Ridge National Laboratory, Oak Ridge, Tenn.

D. R. Johnson. Oak Ridge National Laboratory, Oak Ridge, Tenn.

315 Microwave Processing of Silicon Nitride for Advanced Gas Turbine Applications

Proceedings 38th ASME International Gas Turbine and Aeroengine

Congress/Exhibition, Cincinnati, May 24-27, 1993 (New York: American Society of Mechanical Engineers, 1993)

T. N. Tiegs, J. O. Kiggans. Oak Ridge National Laboratory, Oak Ridge, Tenn.

316 Development of ASTM Standards in Support of Advanced Ceramics Development

Proceedings 38th ASME International Gas Turbine and Aeroengine

Congress/Exhibition, Cincinnati, May 24-27, 1993, pp. 1-11 (New York: American

Society of Mechanical Engineers, 1993)

C. R. Brinkman. Oak Ridge National Laboratory, Oak Ridge, Tenn.

G. D. Quinn. National Institute of Standards and Technology, Gaithersburg, Md.

R. W. McClung. Consultant to Oak Ridge National Laboratory, Oak Ridge, Tenn. 
317 Strength Optimization Through Powder Modification Proceedings of the Fall Meeting, Materials Research Society, Boston, Nov. 30-Dec. 4, 1992 287, pp. 295-302 (Pittsburgh: Materials Research Society, 1993)

A. Pasto. Oak Ridge National Laboratory, Oak Ridge, Tenn.

F. S. Avella, S. Natansohn. GTE Labs, Inc., Wattham, Mass.

W. J. Rourke. Duracell Worldwide Technology Center, Needham, Mass.

318 Apparent Enhanced Fatigue Resistance under Cyclic Tensile Loading for a HIPed Sillicon Nitride

J. Am. Ceram. Soc. 76(3), pp. 788-92 (1993)

M. G. Jenkins, M. K. Ferber. Oak Ridge National Laboratory, Oak Ridge, Tenn.

C.-K. J. Lin. Oak Ridge Institute for Science and Education, Oak Ridge, Tenn.

319 Development of Adherent Ceramic Coatings to Reduce Contact Stress Damage of Ceramics

ORNL/Sub/89-95915/2 (November 1992)

S. F. Wayne, J. H. Selverian, D. O'Neil. GTE Laboratories, Inc., Waltham, Mass.

320 Evaluation of Sialon Internal Combustion Engine Components and Fabrication of Several Ceramic Components for Automotive Applications ORNL/M-22553 (October 1992)

C. H. McMurtry, M. O. Ten Eyck. The Carborundum Company, Niagara Falls, N.Y.

321 Development of Improved Processing Methods for High Reliability Structural Ceramics for Advanced Heat Engines ORNL/Sub/89-SD548/1 (July 1992)

A. E. Pasto, S. Natansohn. GTE Laboratories, Inc., Waltham, Mass.

322 Ceramic Technology Project Database: March 1990 Summary Report ORNL/M-1860 (July 1992)

B. L. P. Keyes. Oak Ridge National Laboratory, Oak Ridge, Tenn.

323 Ceramic Technology Project Database: September 1991 Summary Report

ORNL/M-1862 (June 1992)

B. L. P. Keyes. Oak Ridge National Laboratory, Oak Ridge, Tenn.

324 Ceramic Technology Project Database: September 1990 Summary

Report

ORNL/M-1861 (June 1992)

B. L. P. Keyes. Oak Ridge National Laboratory, Oak Ridge, Tenn.

325 Development of Wear-Resistant Ceramic Coating for Diesel Engine Components, Volume 1: Coating Development and Tribological Testing, Final Report

ORNL/Sub/87-SA581/1 (June 1992)

M. G. S. Naylor. Cummins Engine Company, Inc., Columbus, Ind.

326 Development of Ceramic Matrix Composites for Application in the Ceramic Technology for Advanced Heat Engines Project Phase IIA. Development of In-Situ Toughened Silicon Nitride

ORNL/Sub/85-22008/3 (June 1992)

J. Pollinger, D. Newson, H. Yeh, E. Solidum, J. Yamanis, M. Behi, C.-W. Li, P. Whalen.

Garrett Ceramic Components Division, Torrance, Calif. 
327 Reliability Improvements of High Strength Silicon Nitride Through Process Optimization and Control

Proceedings of the Annual Automotive Technology Development Contractors' Coordination Meeting 1991 P-256, pp. 137-44 (Warrendale, Pa.: Society of Automotive Engineers, June 1992)

V. K. Pujari, D. M. Tracey, N. D. Corbin, M. R. Foley, A. K. Garg, N. I. Paille, P. J. Pelletier, L. C. Sales, C. A. Willkens, R. L. Yeckley. Norton Co., Northboro, Mass.

328 Life Prediction Methodology of Ceramic Engine Components Proceedings of the Annual Automotive Technology Development Contractors' Coordination Meeting 1991 P-256, pp. 253-59 (Warrendale, Pa.: Society of Automotive Engineers, June 1992)

P. K. Khandelwal, D. L. Vaccari. Allison Gas Turbine Division, General Motors Corp., Indianapolis, Ind.

329 Progress in Life Prediction Methodology for Ceramic Components of Advanced Heat Engines

Proceedings of the Annual Automotive Technology Development Contractors' Coordination Meeting 1991 P-256, pp. 261-72 (Warrendale, Pa.: Society of Automotive Engineers, June 1992)

H. T. Fang, J. S. Cuccio, J. C. Wade, K. G. Seybold. AlliedSignal, Inc., Phoenix, Ariz.

M. G. Jenkins. Oak Ridge National Laboratory, Oak Ridge, Tenn.

330 Tensile Creep Testing of Structural Ceramics

Proceedings of the Annual Automotive Technology Development Contractors' Coordination Meeting 1991 P-256, pp. 273-80 (Warrendale, Pa.: Society of Automotive Engineers, June 1992)

S. M. Wiederhorn, R. Krause, D. C. Cranmer. National Institute of Standards and Technology, Gaithersburg, Md.

331 Evaluation of the Elevated-Temperature Mechanical Reliability of a HIPed Silicon Nitride

Proceedings of the Annual Automotive Technology Development Contractors' Coordination Meeting 1991 P-256, pp. 281-91 (Warrendale, Pa.: Society of Automotive Engineers, June 1992)

M. K. Ferber, M. G. Jenkins. Oak Ridge National Laboratory, Oak Ridge, Tenn.

332 Creep Testing of SNW-1000 Sintered Silicon Nitride

Proceedings of the Annual Automotive Technology Development Contractors' Coordination Meeting 1991 P-256, pp. 293-305 (Warrendale, Pa.: Society of Automotive Engineers, June 1992)

J. Sankar, A. D. Kelkar, R. Vaidyanathan, J. Gao. North Carolina A\&T State University, Greensboro, N.C.

333 Statistical Procedures for Estimating Component Strengths and Associated Confidence Bounds

Proceedings of the Annual Automotive Technology Development Contractors' Coordination Meeting 1991 P-256, pp. 385-95 (Warrendale, Pa.: Society of Automotive Engineers, June 1992)

C. A. Johnson, W. T. Tucker. General Electric Corporate Research and Development, Schenectady, N.Y. 
334 Mechanical Testing of Candidate $\mathrm{Si}_{3} \mathrm{~N}_{4}$ Ceramics

Proceedings of the Annual Automotive Technology Development Contractors' Coordination Meeting 1991 P-256, pp. 397-401 (Warrendale, Pa.: Society of Automotive Engineers, June 1992)

N. L. Hecht, S. M. Goodrich, L. Chuck, D. E. McCullum. University of Dayton Research Institute, Dayton, Ohio

335 Wear-Resistant Ceramic Coatings

Proceedings of the Annual Automotive Technology Development Contractors' Coordination Meeting 1991 P-256, pp. 403-15 (Warrendale, Pa.: Society of Automotive Engineers, June 1992)

M. G. S. Naylor. Cummins Engine Co., Inc., Columbus, Ind.

336 Development of Wear Resistant Ceramic Coatings for Diesel Engines Proceedings of the Annual Automotive Technology Development Contractors' Coordination Meeting 1991 P-256, pp. 417-24 (Warrendale, Pa.: Society of Automotive Engineers, June 1992)

M. H. Haselkorn, F. A. Kelley. Caterpillar, Inc., Peoria, III.

337 The Cost-Effective Ceramic Machining Program Plan

Proceedings of the Annual Automotive Technology Development Contractors' Coordination Meeting 1991 P-256, pp. 425-31 (Warrendale, Pa.: Society of Automotive Engineers, June 1992)

P. J. Blau. Oak Ridge National Laboratory, Oak Ridge, Tenn.

338 Nondestructive Evaluation Development for Process Control of Ceramics Proceedings of the Annual Automotive Technology Development Contractors' Coordination Meeting 1991 P-256, pp. 433-37 (Warrendale, Pa.: Society of Automotive Engineers, June 1992)

W. A. Ellingson, D. L. Holloway, E. A. Sivers. Argonne National Laboratory, Argonne, III. J. Ling. Chinese Academy of Sciences.

J. P. Pollinger, H. C. Yeh. AlliedSignal, Inc., Torrance, Calif.

339 Development of UItra-Low-Expansion Ceramics: CMZP and CMZP Matrix Composites

Proceedings of the Annual Automotive Technology Development Contractors' Coordination Meeting 1991 P-256, pp. 145-57 (Warrendale, Pa.: Society of Automotive Engineers, June 1992)

D. A. Hirschfeld, Y. P. Yang, T. K. Li, J. J. Brown. Virginia Polytechnic Institute and State University, Blacksburg, Va.

340 In-Situ Reinforced Silicon Nitride

Proceedings of the Annual Automotive Technology Development Contractors' Coordination Meeting 1991 P-256, pp. 159-65 (Warrendale, Pa.: Society of Automotive Engineers, June 1992)

H. Yeh, D. Newson, J. Pollinger, E. Solidum. AlliedSignal, Inc., Torrance, Calif. J. Yamanis, M. Behi, C.-W. Li, P. Whalen. AlliedSignal, Inc., Morristown, N. J.

341 Improved Processing of Ceramic Composites and Cost Effective Sintering of $\mathrm{Si}_{3} \mathrm{~N}_{4}$ Proceedings of the Annual Automotive Technology Development Contractors' Coordination Meeting 1991 P-256, pp. 167-70 (Warrendale, Pa.: Society of Automotive Engineers, June 1992)

D. E. Wittmer, T. E. Paulson, D. Doshi. Southern Illinois University, Carbondale, III.

C. W. Miller, Jr. Centorr Furnaces/Nacuum Industries, Nashua, N. H. 
342 Scalability Demonstration Program for Silicon Nitride by the Sullivan ${ }^{T M}$ Process for Advanced Ceramics

Proceedings of the Annual Automotive Technology Development Contractors' Coordination Meeting 1991 P-256, pp. 171-75 (Warrendale, Pa.: Society of Automotive Engineers, June 1992)

T. M. Sullivan. Sullivan Mining Corp., San Diego, Calif.

343 Development of a High Temperature Hexoloy SX Silicon Carbide Proceedings of the Annual Automotive Technology Development Contractors' Coordination Meeting 1991 P-256, pp. 177-81 (Warrendale, Pa.: Society of Automotive Engineers, June 1992)

K. Chia, G. V. Srinivasan, S. K. Lau, R. S. Storm. The Carborundum Company, Niagara Falls, N. Y.

344 Development of $\mathrm{Si}_{3} \mathrm{~N}_{4}$ in the System $\mathrm{Si}_{3} \mathrm{~N}_{4}-\mathrm{Y}_{2} \mathrm{O}_{3}-\mathrm{SiO}_{2}-\mathrm{MO}_{2} \mathrm{C}$ Proceedings of the Annual Automotive Technology Development Contractors' Coordination Meeting 1991 P-256, pp. 247-51 (Warrendale, Pa.: Society of

Automotive Engineers, June 1992)

B. Mikijelj, J. Mangels. Ceradyne, Inc., Costa Mesa, Calif.

345 Tribology of Improved Transformation-Toughened Ceramics-Heat Engine Test. Final Report ORNL/Sub/90-SG372/1 (April 1992)

E. Lilley, G. A. Rossi, P. J. Pelletier, Norton Company, Northboro, Mass.

346 Material Development in the $\mathrm{Si}_{3} \mathrm{~N}_{4}$ System Using Glass Encapsulated Hip'ing. Final Report, Phase II ORNL/Sub/86-95906/2 (April 1992)

N. D. Corbin, G. J. Sundberg, K. N. Siebein, C. A. Willkens, V. K. Pujari, G. A. Rossi, J. S. Hansen, C. L. Chang, J. L. Hammarstrom. Norton Company, Northboro, Mass.

347 Analytical and Experimental Evaluation of Joining Ceramic Oxides to Ceramic Oxides and Ceramic Oxides to Metal for Advanced Heat Engine Applications. Final Report

ORNL/Sub/87-SB046/1 (April 1992)

J. Ahman, B. Majumdar, A. R. Rosenfield, S. L. Swartz, J. Cawley, E. Park, D. Hauser, A.

T. Hopper. Battelle Columbus Laboratories, Columbus, Ohio

348 Effect of Trans/ucence of Engineering Ceramics on Heat Transfer in Diesel Engines. Final Report.

ORNL/Sub/88-22042/2 (April 1992)

S. Wahiduzzaman, T. Morel. Integral Technologies Inc., Westmont, III.

349 Interference of Wedge-Shaped Protrusions on the Faces of a Griffith Crack in Biaxial Stress. Final Report

ORNL/Sub/87-07685/2 (April 1992)

J. A. M. Boulet. University of Tennessee, Knoxville, Tenn.

350 Development of Low-Expansion Ceramics for Diesel Engine Applications. Final Report

ORNL/Sub/86-22049/1 (April 1992)

J. J. Brown, Jr. Virginia Polytechnic Institute and State University, Blacksburg, Va. 
351 Development of Ceramic Matrix Composites for Application in Ceramic Technology for Advanced Heat Engine Program. Final Report ORNLSub/85-22011/2 (April 1992)

S. T. Buljan, J. G. Baldoni, M. L. Huckabee, J. Neil, J. Hefter. GTE Laboratories, Inc., Wattham, Mass.

352 Development of Ceramic Matrix Composites for Application in Ceramic Technology for Advanced Heat Engine Program. Final Report, Phase II ORNL/Sub/85-22008/2 (April 1992)

H. Yeh, E. Solidum, K. Karasek, G. Stranford, D. Yuhas, J. Schienle, S. Bradley.

AlliedSignal, Inc., Torrance, Calif.

353 Analytical and Experimental Evaluation of Joining Silicon Carbide to Silicon Carbide and Silicon Nitride to Silicon Nitride for Heat Engine Applications. Final Report ORNL/Sub/87-SB045/1 (April 1992)

M. R. Foley, G. A. Rossi, G. J. Sundberg, J. A. Wade, F. J. Wu. Norton Company, Northboro, Mass.

354 Development of Adherent Ceramic Coatings to Reduce Contact Stress Damage of Ceramics. Final Report

ORNL/Sub/86-95915/1 (April 1992)

C. D'Angelo, H. J. Kim, D. W. Oblas, H. E. Rebenne, V. K. Sarin. GTE Laboratories, Inc., Waltham, Mass.

355 Processing of Sinterable Transformation Toughened Ceramics for Application in Ceramic Technology for Advanced Heat Engines Project. Final Report, Phase II

ORNL/Sub/85-22031/2 (April 1992)

E. Lilley, G. A. Rossi. Norton Company, Northboro, Mass.

356 Interference of Wedge-Shaped Protrusions on the Faces of a Griffith Crack in Biaxial Stress. Final Report

ORNL/Sub/87-07685/1 (April 1992)

J. A. M. Boulet. University of Tennessee, Knoxville, Tenn.

357 Evaluation of Silicon Nitride Internal Combustion Engine Components. Final Report

ORNLSub/89-SE500/1 (April 1992)

W. Voldrich. Garrett Ceramic Components Division, Torrance, Calif.

358 Studies of Dynamic Contact of Ceramics and Alloys for Advanced Heat Engines. Final Report

ORNL/Sub/84-00216/1 (April 1992)

P. A. Gaydos, K. F. Dufrane. Battelle Columbus Division, Columbus, Ohio

359 Engine Testing of Ceramic Cam-Roller Followers

ORNL/Sub/90-SF985/1 (April 1992)

Y. Kalish. Detroit Diesel Corporation, Detroit, Mich.

360 Development of Wear Resistant Ceramic Coatings for Diesel Engine Components. Final Report

ORNL/Sub/87-SA582/1 (April 1992)

M. H. Haselkorn. Caterpillar, Inc., Peoria, III. 
361 Reinforcements for High Temperature Ceramics. Final Report ORNL/Sub-90/SB688/1 (April 1992)

C. I. Kyriacou, J. L. Sepulveda, M. A. Watson. Keramont, Tucson, Ariz.

362 Ceramic Technology Project Semiannual Progress Report for April 1991 Through September 1991

ORNLTM-11984 (March 1992)

D. R. Johnson. Oak Ridge National Laboratory, Oak Ridge, Tenn.

363 The Cost of Silicon Nitride Powder: What Must it Be To Compete? ORNL-6694 (February 1992)

S. Das, T. R. Curlee. Oak Ridge National Laboratory, Oak Ridge, Tenn.

364 A Review of Techniques for Joining Advanced Ceramics Am. Ceram. Soc. Bull. 71(6), pp. 947-54 (1992)

M. L. Santella. Oak Ridge National Laboratory, Oak Ridge, Tenn.

365 Pressure Casting Process Control by U/trasonic Technique Ceramic Engineering \& Science Proceedings 13(7), pp. 536-45 (Westerville, Ohio: American Ceramic Society, 1992) V. K. Pujari, L. C. Sales. Norton Co., Northboro, Mass.

J. S. Wang, J. Fraser. Precision Acoustics Devices, Inc., Fremont, Calif.

366 Continuous Sintering of $\mathrm{Si}_{3} \mathrm{~N}_{4}$ in a Controlled Atmosphere Belt Furnace Ceramic Engineering \& Science Proceedings 13(7), pp. 546-61 (Westerville, Ohio: American Ceramic Society, 1992)

D. E. Wittmer, T. E. Paulson. Southem Illinois University, Carbondale, III.

C. W. Miller, Jr. Centorr FurnacesNacuum Industries, Nashua, N. H.

367 Twisting and Friction Errors in Flexure Testing

Ceramic Engineering \& Science Proceedings 13(7), pp. 319-30 (Westerville, Ohio: American Ceramic Society, 1992)

G. D. Quinn. National Institute of Standards and Technology, Gaithersburg, Md.

368 Ceramic-Metal Joints Brazed with Palladium Alloys

J. Am. Welding Soc. 71(1), pp. 25s-35s (1992)

J. H. Selverian, S. Kang. GTE Laboratories, Inc., Waltham, Mass.

369 The Role of Ion Species on the Adhesion Enhancement of Ion Beam Mixed $\mathrm{Fe}_{\mathrm{A}} \mathrm{I}_{2} \mathrm{O}_{3}$ Systems

Proceedings of the Fall Meeting of the Materials Research Society, Boston, December 26, 1991 238, pp. 793-98 (Pittsburgh, Pa.: Materials Research Society, 1992)

J. E. Pawel, C. J. McHargue, L. J. Romana, L. L. Horton, J. J. Wert. Oak Ridge National Laboratory, Oak Ridge, Tenn.

370 Ion Beam Enhanced Adhesion of Iron Films to Sapphire Substrates Surf. Coatings Technol. 51, pp. 129-32 (1992)

J. E. Pawel, C. J. McHargue, L. J. Romana, J. J. Wert. Oak Ridge National Laboratory, Oak Ridge, Tenn.

371 Study and Analysis of the Stress State in a Ceramic, Button-Head, Tensile Specimen ORNL/TM-11767 (September 1991)

M. G. Jenkins, M. K. Ferber, R. L. Martin, V. T. Jenkins, V. J. Tennery. Oak Ridge National Laboratory, Oak Ridge, Tenn. 
372 Report on the Planning Workshop on Cost-Effective Ceramic Machining ORNL/M-1745 (November 1991)

P. J. Blau. Oak Ridge National Laboratory, Oak Ridge, Tenn.

373 Ceramic Technology for Advanced Heat Engines Project Semiannual Progress Report for October 1990 Through March 1991 ORNLTM-11859 (July 1991)

D. R. Johnson. Oak Ridge National Laboratory, Oak Ridge, Tenn.

374 Gelcasting-A New Ceramic Forming Process

Am. Ceram. Soc. Bull. 70(1), pp. 1641-49 (1991)

O. O. Omatete, M. A. Janney, R. A. Strehlow. Oak Ridge National Laboratory, Oak Ridge, Tenn.

375 High Temperature Degradation of Structural Composites Ceram. Int. 17, pp. 243-52 (1991)

S. M. Wiederhorn, B. J. Hockey. National Institute of Standards and Technology, Gaithersburg, Md.

376 Microstructural Characterization of Creep-Deformed SiC WhiskerReinforced $\mathrm{Si}_{3} \mathrm{~N}_{4}$ Composite

Ultramicroscopy 37, p. 263 (1991)

K. L. More. Oak Ridge National Laboratory, Oak Ridge, Tenn.

D. A. Koester, R. F. Davis. North Carolina State University, Raleigh, N. C.

377 Deformation and Microstructural Changes in SiC Whisker-Reinforced $\mathrm{Si}_{3} \mathrm{~N}_{4}$ Composites

J. Mater. Res. 6(12), p. 2735 (1991)

D. A. Koester, R. F. Davis. North Carolina State University, Raleigh, N. C.

K. L. More. Oak Ridge National Laboratory, Oak Ridge, Tenn.

378 Defect Characterization in a CVD $\alpha \mathrm{Si}_{3} \mathrm{~N}_{4}$

Proceedings of the 49th Annual Meeting of the Electron Microscopy Society of America, ed. G. W. Bailey, pp. 936-37 (San Francisco: San Francisco Press, 1991)

K. L. More. Oak Ridge National Laboratory, Oak Ridge, Tenn.

379 Ceramic Technology for Advanced Heat Engines Project. Semiannual Progress Report for April 1990 Through September 1990

ORNLTM-11719 (December 1990)

D. R. Johnson. Oak Ridge National Laboratory, Oak Ridge, Tenn.

380 Ceramic Technology for Advanced Heat Engines Project Database: September 1989 Summary Report

ORNLM-1286 (October 1990)

B. L. P. Keyes. Oak Ridge National Laboratory, Oak Ridge, Tenn.

381 Mechanical Behavior of a SiC-Fiber/Si3N 4 Composite

MTL TN 90-2* (September 1990)

J. J. Swab, G. D. Quinn, D. J. Snoha. U.S. Army Materials Technology Laboratory, Watertown, Mass.

"Available from the U.S. Army Materials Technology Laboratory, Watertown, Mass. 02172-0001. 
382 The Evaluation of Environmental Effects in Toughened Ceramics for Advanced Heat Engines Investigation of Selected SiC and $\mathrm{Si}_{3} \mathrm{~N}_{4}$ Ceramics ORNL/Sub/84-00221/2 (August 1990)

N. L. Hecht, G. A. Graves, D. E. McCullum, A. P. Berens, S. Goodrich, J. D. Wolf, J. R. Hoenigman, P. Yaney, D. Grant, S. Hilton. University of Dayton Research Center, Dayton, Ohio

383 Synthesis of High Purity Sinterable $\mathrm{Si}_{3} \mathrm{~N}_{4}$ Powders

ORNL/Sub/85-SB012/1 (August 1990)

G. M. Crosbie, R. L. Predmesky, J. M. Nicholson. Ford Motor Co., Dearbom, Mich.

384 Ceramic Technology for Advanced Heat Engines Project. Semiannual Progress Report for April 1989 Through September 1989 ORNLTM-11489 (August 1990)

D. R. Johnson. Oak Ridge National Laboratory, Oak Ridge, Tenn.

385 Influence of Diesel Engine Exposure on the Rupture Strength of Silicon Nitride and Partially Stabilized Zirconia

ORNL-6612 (June 1990)

C. R. Brinkman, G. M. Begun, R. L. Graves, W. K. Kahl, K. C. Liu, B. H. West. Oak Ridge National Laboratory, Oak Ridge, Tenn.

386 Effect of Environment upon Mechanical Behavior of Structural Ceramics for Application in the DOE Ceramic Technology for Advanced Heat Engines Project. Final Report, January 1985 December 1986 ORNL/Sub/84-00221/1 (June 1990)

N. L. Hecht, G. A. Graves, D. E. McCullum, A. P. Berens, S. Goodrich, J. D. Wolf, J. R. Hoenigman, P. Yaney, D. Grant, S. Hilton, S. D. Jang. University of Dayton Research Institute, Dayton, Ohio

387 Analytical and Experimental Evaluation of Joining Silicon Nitride to Metal and Silicon Carbide to Metal for Advanced Heat Engine Applications.

Final Report Phase I

ORNL/Sub/87-SB047C/1 (April 1990)

S. Kang, J. H. Selverian, H. Kim, D. O'Neil. GTE Laboratories, Inc., Waltham, Mass.

K. Kim. Brown University, Providence, R.I.

388 Ceramic Technology for Advanced Heat Engines Project Data Base: March 1989 Summary Report

ORNL/M-1098 (April 1990)

B. L. P. Keyes. Oak Ridge National Laboratory, Oak Ridge, Tenn.

389 Development of Wear-Resistant Ceramic Coatings for Diesel Engine Components

Proceedings of the Twenty-Seventh Automotive Technology Development Contractors' Coordination Meeting P-230, pp. 131-41 (Warrendale, Pa.: Society of Automotive Engineers, Inc., April 1990)

M. G. S. Naylor, M. P. Fear. Cummins Engine Company, Inc., Columbus, Ind.

390 Wear-Resistant Ceramic Coatings for Diesel Engine Components Proceedings of the Twenty-Seventh Automotive Technology Development Contractors' Coordination Meeting P-230, pp. 143-48 (Warrendale, Pa.: Society of Automotive Engineers, Inc., April 1990)

M. H. Haselkom, F. A. Kelley, C. D. Weiss. Caterpillar, Inc., Peoria, III. 
391 Studies of Dynamic Contact of Ceramics and Alloys for Advanced Heat Engines

Proceedings of the Twenty-Seventh Automotive Technology Development Contractors' Coordination Meeting P-230, pp. 149-53 (Warrendale, Pa.: Society of Automotive Engineers, Inc., April 1990)

P. A. Gaydos, K. F. Dufrane. Battelle Columbus Laboratories, Columbus, Ohio

392 Identification and Development of Optimum Silicon Carbide Whiskers for Silicon Nitride Matrix Composites

Proceedings of the Twenty-Seventh Automotive Technology Development Contractors' Coordination Meeting P-230, pp. 167-72 (Warrendale, Pa.: Society of Automotive Engineers, Inc., April 1990)

T. N. Tiegs, L. F. Allard, P. F. Becher, M. K. Ferber. Oak Ridge National Laboratory, Oak Ridge, Tenn.

393 Synthesis of High-Purity Sinterable Silicon Nitride Powder Proceedings of the Twenty-Seventh Automotive Technology Development Contractors' Coordination Meeting P-230, pp. 191-96 (Warrendale, Pa.: Society of Automotive Engineers, Inc., April 1990)

G. M. Crosbie, R. L. Predmesky, J. M. Nicholson. Ford Motor Co., Dearborn, Mich.

394 Advanced Processing of High-Performance Silicon Nitride Ceramics Proceedings of the Twenty-Seventh Automotive Technology Development Contractors' Coordination Meeting P-230, pp. 197-206 (Warrendale, Pa.: Society of Automotive Engineers, Inc., April 1990)

A. E. Pasto, S. Natansohn. GTE Laboratories, Inc., Waltham, Mass.

395 Material Development in the Silicon Nitride-Silicon Carbide Whisker System

Proceedings of the Twenty-Seventh Automotive Technology Development Contractors' Coordination Meeting P-230, pp. 207-13 (Warrendale, Pa.: Society of Automotive Engineers, Inc., April 1990)

N. D. Corbin, K. N. Siebein, J. S. Hansen, G. J. Sundberg, V. K. Pujari, G. A. Rossi. Norton Co., Northboro, Mass.

396 Mechanical Properties Characterization of High Performance Ceramics Proceedings of the Twenty-Seventh Automotive Technology Development Contractors' Coordination Meeting P-230, pp. 217-33 (Warrendale, Pa.: Society of Automotive Engineers, Inc., April 1990)

N. L. Hecht, D. E. McCullum, S. Goodrich, L. Chuck. University of Dayton Research Institute, Dayton, Ohio

397 High Temperature Tensile and Fatigue Strengths of Silicon Nitride Proceedings of the Twenty-Seventh Automotive Technology Development Contractors' Coordination Meeting P-230, pp. 235-44 (Warrendale, Pa.: Society of Automotive Engineers, Inc., April 1990)

K. C. Liu, C. R. Brinkman. Oak Ridge National Laboratory, Oak Ridge, Tenn.

398 Numerical and Empirical Verification of the Stress State in a Ceramic, Button-head, Tensile Specimen

Proceedings of the Twenty-Seventh Automotive Technology Development Contractors' Coordination Meeting P-230, pp. 245-50 (Warrendale, Pa.: Society of Automotive Engineers, Inc., April 1990)

M. G. Jenkins, M. K. Ferber, R. L. Martin, V. J. Tennery. Oak Ridge National Laboratory, Oak Ridge, Tenn. 
399 Tensile Creep of SiC Whisker Reinforced Silicon Nitride

Proceedings of the Twenty-Seventh Automotive Technology Development Contractors' Coordination Meeting P-230, pp. 251-64 (Warrendale, Pa.: Society of Automotive Engineers, Inc., April 1990)

B. J. Hockey, S. M. Wiederhorn, W. Liu. National Institute of Standards and Technology, Gaithersburg, Md.

J. G. Baldoni, S.-T. Buljan. GTE Laboratories, Inc., Waltham, Mass.

400 Fracture Strength Analysis of Silicon Nitride and Silicon Carbide Ceramics from an International Cooperative Research Program Proceedings of the Twenty-Seventh Automotive Technology Development Contractors' Coordination Meeting P-230, pp. 265-73 (Warrendale, Pa.: Society of Automotive Engineers, Inc., April 1990)

V. J. Tennery, M. K. Ferber. Oak Ridge National Laboratory, Oak Ridge, Tenn.

401 Life Prediction Methodology for Ceramic Components of Advanced Heat Engines

Proceedings of the Twenty-Seventh Automotive Technology Development Contractors' Coordination Meeting P-230, pp. 275-82 (Warrendale, Pa.: Society of Automotive Engineers, Inc., April 1990)

A. M. Comfort, J. S. Cuccio. AlliedSignal, Inc., Phoenix, Ariz.

402 Low Temperature Degradation of Y-TZP Materials

MTL TR 90-4* (January 1990)

J. J. Swab. U.S. Army Materials Technology Laboratory, Watertown, Mass.

403 Performance of $\mathrm{Y}$-TZP Materials Between $800^{\circ} \mathrm{C}$ and $1200^{\circ} \mathrm{C}$ MTL TR $90-3^{*}$ (January 1990)

J. J. Swab. U.S. Army Materials Technology Laboratory, Watertown, Mass.

404 Elevated-Temperature-Delayed Failure of Alumina Reinforced With 20 Vol \% Silicon Carbide Whiskers

J. Mater. Sci. 73, pp. 91-96 (1990)

P. F. Becher, P. Angelini, W. H. Warwick, T. N. Tiegs. Oak Ridge National Laboratory, Oak Ridge, Tenn.

405 A New Method for Analyzing Data from Continuous Depth-Sensing Microindentation Tests

J. Mater. Res. 5, pp. 123-26 (1990)

D. L. Joslin. University of Tennessee, Knoxville, Tenn.

W. C. Oliver. Oak Ridge National Laboratory, Oak Ridge, Tenn.

406 Thermal Diffusivity/Conductivity of Alumina-Silicon Carbide J. Am. Ceram. Soc. 73, pp. 461-64 (1990)

P. H. McCluskey. Alfred University, Alfred, N.Y.

R. K. Williams, R. S. Graves, T. N. Tiegs. Oak Ridge National Laboratory, Oak Ridge, Tenn.

407 Effect of Aspect Ratio and Liquid Phase Content on Densification of Alumina-SiC Whisker Composites

J. Am. Ceram. Soc. 73(5), pp. 1440-42 (1990)

T. N. Tiegs. Oak Ridge National Laboratory, Oak Ridge, Tenn.

D. M. Dillard. Georgia Institute of Technology, Atlanta, Ga.

- Available from the U.S. Army Materials Technology Laboratory, Watertown, Mass. 02172-0001. 
408 Creep Behavior of an SiC-Whisker-Reinforced Alumina J. Am. Ceram. Soc. 73, pp. 1378-81 (1990)

H. T. Lin, P. F. Becher. Oak Ridge National Laboratory, Oak Ridge, Tenn.

409 The Role of Interfaces in the Creep-Deformation of an SiC WhiskerReinforced $\mathrm{Si}_{3} \mathrm{~N}_{4}$ Composite

Proceedings of the Twelfth International Congress for Electron Microscopy, Seattle,

August 12-18, 1990, pp. 382-83 (San Francisco: San Francisco Press, Inc., 1990)

K. L. More. Oak Ridge National Laboratory, Oak Ridge, Tenn.

D. A. Koester, R. F. Davis. North Carolina State University, Raleigh, N.C.

410 Synthesis of High Purity Sinterable Silicon Carbide Powder ORNL/Sub/84-00214/1 (November 1989)

W. D. Boecker, B. L. Mehosky, R. S. C. Rogers, R. S. Storm, V. Venkateswaran. The Carborundum Company, Structural Ceramics Division, Niagara Falls, N.Y.

411 Ceramic Technology for Advanced Heat Engines Project Semiannual Progress Report for October 1988 Through March 1989 ORNL/TM-11239 (August 1989)

D. R. Johnson. Oak Ridge National Laboratory, Oak Ridge, Tenn.

412 IEA/Annex || Powder Characterization Cooperative Program MTL TR 89-53* (June 1989)

T. M. Resetar, J. W. McCauley. U.S. Army Materials Technology Laboratory, Watertown, Mass.

G. E. Schaefer. W. R. Grace Company, Cambridge, Mass.

A. L. Dragoo, S. M. Hsu. National Institute of Standards and Technology, Gaithersburg, Md.

D. R. Johnson. Oak Ridge National Laboratory, Oak Ridge, Tenn.

H. Hausner. Technical University of Berlin, Berlin, FRG

R. Pompe. Swedish Institute for Silicate Research, Göteborg, Sweden

413 Life Prediction Methodology for Ceramic Components

Proceedings of the 26th Automotive Technology Development Contractors'

Coordination Meeting, Dearborn, Michigan, October 24-27, 1988, pp. 257-62

(Warrendale, Pa.: Society of Automotive Engineers, Inc., April 1989)

D. L. Vaccari, P. K. Khandelwal. Allison Gas Turbine Div., General Motors Corp., Indianapolis, Ind.

414 Development of Silicon Carbide Whisker Reinforced Silicon Nitride Formed by slip Casting

Proceedings of the 26th Automotive Technology Development Contractors'

Coordination Meeting, Dearborn, Michigan, October 24-27, 1988, pp. 251-55

(Warrendale, Pa.: Society of Automotive Engineers, Inc., April 1989)

H. C. Yeh. Garrett Ceramic Components Division, Torrance, Calif.

J. L. Schienle. Garrett Auxiliary Power Div., Phoenix, Ariz.

K. R. Karasek, S. A. Bradley. AlliedSignal, Inc., Des Plaines, III.

415 Silicon Carbide Whisker Reinforced Silicon Nitride

Proceedings of the 26th Automotive Technology Development Contractors'

Coordination Meeting, Dearborn, Michigan, October 24-27, 1988, pp. 243-50

(Warrendale, Pa.: Society of Automotive Engineers, Inc., April 1989)

M. L. Huckabee, J. G. Baldoni, J. T. Neil, G. Zilberstein, S.-T. Buljan. GTE Laboratories, Inc., Waltham, Mass.

* Available from the U.S. Army Materials Technology Laboratory, Watertown, Mass. 02172-0001. 
416 Material Development in the Silicon Nitride-Silicon Carbide Whisker System

Proceedings of the 26th Automotive Technology Development Contractors' Coordination Meeting, Dearborn, Michigan, October 24-27, 1988, pp. 235-41

(Warrendale, Pa.: Society of Automotive Engineers, Inc., April 1989)

N. D. Corbin, C. A. Willkens, J. L. Hammarstrom, V. K. Pujari, G. A. Rossi, K. N. Siebein. Norton Co., Northboro, Mass.

J. S. Hansen, C. L. Chang. Norton Co., Salt Lake City, Utah

417 Development of Improved Processing and Evaluation of Silicon Nitride Proceedings of the 26th Automotive Technology Development Contractors' Coordination Meeting, Dearborn, Michigan, October 24-27, 1988, pp. 227-34

(Warrendale, Pa.: Society of Automotive Engineers, Inc., April 1989)

V. K. Pujari, K. E. Amin, P. H. Tewari, S. D. Hartline. Norton Co., Northboro, Mass.

418 Ceramic Coatings to Reduce Contact Stress Damage of Ceramics

Performance Testing

Proceedings of the 26th Automotive Technology Development Contractors'

Coordination Meeting, Dearborn, Michigan, October 24-27, 1988, pp. 221-26

(Warrendale, Pa.: Society of Automotive Engineers, Inc., April 1989)

D. W. Oblas, C. D'Angelo, H. E. Rebenne, V. K. Sarin. GTE Laboratories, Inc., Waltham, Mass.

419 Dynamic Contact of Ceramics in Ring-Cylinder Applications Proceedings of the 26th Automotive Technology Development Contractors' Coordination Meeting, Dearborn, Michigan, October 24-27, 1988, pp. 145-48

(Warrendale, Pa.: Society of Automotive Engineers, Inc., April 1989)

K. F. Dufrane, P. A. Gaydos. Battelle Columbus Div., Columbus, Ohio

420 Wear Resistant Ceramic Coatings for Diesel Engine Components

Proceedings of the 26th Automotive Technology Development Contractors'

Coordination Meeting, Dearborn, Michigan, October 24-27, 1988, pp. 119-22

(Warrendale, Pa.: Society of Automotive Engineers, Inc., April 1989)

M. Haselkorn, F. Kelley, D. Weiss. Caterpillar, Inc., Peoria, III.

421 Development of Magnetic Resonance Imaging Technology for Imaging Binder Distribution in Ceramics

Proceedings of the 26th Automotive Technology Development Contractors'

Coordination Meeting, Dearborn, Michigan, October 24-27, 1988, pp. 211-17

(Warrendale, Pa.: Society of Automotive Engineers, Inc., April 1989)

W. A. Ellingson, P. S. Wong. Argonne National Laboratory, Argonne, III.

J. L. Ackerman. Massachusetts General Hospital, Boston, Mass.

H. C. Yeh, J. P. Pollinger. AlliedSignal, Inc., Torrance, Calif.

422 Confidence Bounds on Strength Estimates

Proceedings of the 26th Automotive Technology Development Contractors'

Coordination Meeting, Dearborn, Michigan, October 24-27, 1988, pp. 205-10

(Warrendale, Pa.: Society of Automotive Engineers, Inc., April 1989)

W. T. Tucker, C. A. Johnson. GE Corporate R\&D, Schenectady, N.Y.

423 Synthesis and Characterization of Ultra-Low Thermal Expansion Oxide Ceramics

Proceedings of the 26th Automotive Technology Development Contractors'

Coordination Meeting, Dearborn, Michigan, October 24-27, 1988, pp. 187-204

(Warrendale, Pa.: Society of Automotive Engineers, Inc., April 1989)

R. E. Swanson, J. J. Brown. Virginia Polytechnic Institute and State University,

Blacksburg, Va. 
424 Strength and Fatigue of Silicon Nitride in Uniaxial Tension Proceedings of the 26th Automotive Technology Development Contractors' Coordination Meeting, Dearborn, Michigan, October 24-27, 1988, pp. 173-86 (Warrendale, Pa.: Society of Automotive Engineers, Inc., April 1989) J. Sankar, A. Kelkar, A. Sinha. North Carolina A\&T State University, Greensboro, N.C. K. C. Liu. Oak Ridge National Laboratory, Oak Ridge, Tenn.

425 Analytical and Experimental Evaluation of Joining Silicon Nitride to Metal and Silicon Carbide to Metal

Proceedings of the 26th Automotive Technology Development Contractors' Coordination Meeting, Dearborn, Michigan, October 24-27, 1988, pp. 165-71

(Warrendale, Pa.: Society of Automotive Engineers, Inc., April 1989)

E. M. Dunn, S. Kang. GTE Laboratories, Inc., Waltham, Mass.

H. Mizuhara. Wesgo Div., GTE Products Corp., Belmont, Calif.

K. S. Kim. University of Illinois, Uibana, III.

426 Analytical and Experimental Evaluation of Joining Silicon Carbide to Silicon Carbide and Silicon Nitride to Silicon Nitride for Advanced Heat Engine Applications

Proceedings of the 26th Automotive Technology Development Contractors'

Coordination Meeting, Dearborn, Michigan, October 24-27, 1988, pp. 157-63

(Warrendale, Pa.: Society of Automotive Engineers, Inc., April 1989)

G. A. Rossi, D. O. Patten, G. J. Sundberg, C. H. Bates, F. J. Wu. Norton Co., Northboro, Mass.

427 Joining of Zirconia Ceramics with a $\mathrm{CaO}_{-} \mathrm{TiO}_{2}-\mathrm{SiO}_{2}$ Interlayer Proceedings of the 26th Automotive Technology Development Contractors' Coordination Meeting, Dearborn, Michigan, October 24-27, 1988, pp. 149-54 (Warrendale, Pa.: Society of Automotive Engineers, Inc., April 1989) S. L. Swartz, B. S. Majumdar, B. C. Mutsuddy. Battelle Columbus Div., Columbus, Ohio

428 Zirconia Toughened Ceramics for Heat Engine Applications Phase IIA Proceedings of the 26th Automotive Technology Development Contractors' Coordination Meeting, Dearborn, Michigan, October 24-27, 1988, pp. 133-44 (Warrendale, Pa.: Society of Automotive Engineers, Inc., April 1989) E. Lilley, G. A. Rossi. Norton Co., Northboro, Mass.

429 Influence of Diesel Engine Combustion on the Rupture Strength of Partially Stabilized Zirconia

Proceedings of the 26th Automotive Technology Development Contractors' Coordination Meeting, Dearborn, Michigan, October 24-27, 1988, pp. 123-31

(Warrendale, Pa.: Society of Automotive Engineers, Inc., April 1989)

C. R. Brinkman, G. M. Begun, O. B. Cavin, B. E. Foster, R. L. Graves, W. K. Kahl, K. C. Liu, W. A. Simpson. Oak Ridge National Laboratory, Oak Ridge, Tenn.

430 Development of Wear-Resistant Ceramic Coatings for Advanced Diesel Engines

Proceedings of the 26th Automotive Technology Development Contractors' Coordination Meeting, Dearborn, Michigan, October 24-27, 1988, pp. 111-18

(Warrendale, Pa.: Society of Automotive Engineers, Inc., April 1989)

M. G. S. Naylor, M. P. Fear. Cummins Engine Co., Inc., Columbus, Ind.

431 Ceramic Technology for Advanced Heat Engines Project Semiannual Progress Report for April Through September 1988 ORNL/TM-11116 (March 1989)

D. R. Johnson. Oak Ridge National Laboratory, Oak Ridge, Tenn. 


\section{Properties of Yttria-Tetragonal Zirconia Polycrystal (Y-TZP) Materials After Long-Term Exposure to Elevated Temperatures \\ MTL TR $89-21^{\circ}$ (March 1989) \\ J. J. Swab. U.S. Army Materials Technology Laboratory, Watertown, Mass.}

433 Ceramic Technology for Advanced Heat Engines Project Data Base: September 1988 Summary Report ORNL/M-755 (March 1989)

B. L. P. Booker. Oak Ridge National Laboratory, Oak Ridge, Tenn.

434 Thin Film and Near Surface Characterization Using Indentation Systems Proceedings NATO Advanced Study Institute on Structure-Property Relationships in Surface-Modified Ceramics, Ciocco, Italy, August 28-September 9, 1988, pp. 295-302

(Boston; Dordrecht, The Netherlands: Klüwer Academic Publishers, 1989)

D. L. Joslin. University of Tennessee, Knoxville, Tenn.

C. J. McHargue, W. C. Oliver. Oak Ridge National Laboratory, Oak Ridge, Tenn.

435 Exploratory High-Temperature Tensile and Cyclic Fatigue Characterization of Commercial MgO-PSZ

Proceedings Third International Symposium on Ceramic Materials and Components, Las Vegas, November 27-30, 1988, pp. 841-55 (Westerville, Ohio: American Ceramic Society, 1989)

K. C. Liu, C. R. Brinkman. Oak Ridge National Laboratory, Oak Ridge, Tenn.

436 Pre-Pilot Synthesis of Low Carbon $\mathrm{Si}_{3} \mathrm{~N}_{4}$

Proceedings Second International Conference on Ceramic Powder Processing Science, Berchtesgaden, FRG, October 12-14, 1988, pp. 269-73 (Bad Honnef: Deutsche Keramische Gesellschaft, 1989)

G. M. Crosbie, J. M. Nicholson, R. L. Predmesky, E. D. Stiles. Ford Motor Company, Dearborn, Mich.

437 Laser Diffraction Methods for High Temperature Strain Measurements Proceedings Spring Conference on Experimental Mechanics, Cambridge, Mass., May 28-June 2, 1989, pp. 87-93 (Society of Experimental Mechanics, 1989)

H. Pih. University of Tennessee, Knoxville, Tenn.

K. C. Liu. Oak Ridge National Laboratory, Oak Ridge, Tenn.

438 Theoretical and Experimental Analysis of the Toughening Behavior of Whisker Reinforcement in Ceramic Matrix Composites Mater. Sci. Eng. A107, pp. 257-59 (1989)

P. F. Becher, C. H. Hsueh, P. Angelini, T. N. Tiegs. Oak Ridge National Laboratory, Oak Ridge, Tenn.

\footnotetext{
- Available from the U.S. Army Materials Technology Laboratory, Watertown, Mass. 02172-0001.
} 



\section{ALTERnAtive FUELS AND PROPULSION TECHNOLOGY}

439 Controlling Chaos in Spark-Ignition Engines

Proceedings Central and Eastem States Sections Joint Technical Meeting of the

Combustion Institute, New Orleans, March 15-17, 1993, pp. 675-79 (The Combustion Institute, 1993)

R. M. Wagner. University of Missouri-Rolla, Rolla, Mo.

C. S. Daw, J. F. Thomas. Oak Ridge National Laboratory, Oak Ridge, Tenn.

440 Federal Methanol Fleet Project. Final Report

ORNLTM-12278 (March 1993)

B. H. West, R. N. McGill, S. L. Hillis. Oak Ridge National Laboratory, Oak Ridge, Tenn.

J. W. Hodgson. University of Tennessee, Knoxville, Tenn.

441 Heat Transfer Effectiveness of a Thermal Barrier Coating with Different

Fuel Compositions

ORNLTM-11816 (June 1991)

N. Domingo. Oak Ridge National Laboratory, Oak Ridge, Tenn.

442 Results from the Third Year of Operation of the Federal Methanol Fleet at Argonne National Laboratory

ORNLTM-11736 (January 1991)

B. H. West, R. N. McGill. Oak Ridge National Laboratory, Oak Ridge, Tenn.

S. L. Hillis, J. W. Hodgson. University of Tennessee, Knoxville, Tenn.

443 Neat Methanol Combustion in a DI Diesel Engine Using Catalytically Coated Glow Plugs

Alternative Liquid Fuels in Transportation, pp. 97-105, proceedings of the International Fuels and Lubricants Meeting and Exposition, Toronto, Ontario, Canada, October 7-10, 1991, SAE Special Publication 889 (Warrendale, Pa.: Society of Automotive Engineers, 1991)

W. Mitchell, T. A. Litzinger, D. A. Santavicca. The Pennsylvania State University, University Park, Pa.

444 High-Alcohol Microemulsion Fuel Performance in a Diesel Engine SAE* Paper 902101, presented at the 1990 SAE Intemational Fuels and Lubricants Meeting and Exposition, October 22-25, 1990, Tulsa, Oklahoma

B. H. West, A. L. Compere, W. L. Griffith. Oak Ridge National Laboratory, Oak Ridge, Tenn.

445 Interpretation of Engine Cycle-to-Cycle Variation by Chaotic Time Series Analysis

SAE Paper 902103, presented at the 1990 SAE International Fuels and Lubricants Meeting and Exposition, October 22-25, 1990, Tulsa, Oklahoma

C. S. Daw, W. K. Kahl. Oak Ridge National Laboratory, Oak Ridge, Tenn.

446 Results from the Second Year of Operation of the Federal Methanol Fleet at Oak Ridge National Laboratory

ORNLTM-11622 (September 1990)

B. H. West, R. N. McGill. Oak Ridge National Laboratory, Oak Ridge, Tenn.

S. L. Hillis. University of Tennessee, Knoxville, Tenn.

"SAE papers are available from the Society of Automotive Engineers International, 400 Commonwealth Drive, Warrendale PA 15096-0001. 
447 Results from the Fourth Year of Operation of the Federal Methanol Fleet at Lawrence Berkeley Laboratory ORNLTM-11590 (August 1990)

B. H. West, R. N. McGill. Oak Ridge National Laboratory, Oak Ridge, Tenn.

S. L. Hillis. University of Tennessee, Knoxville, Tenn.

448 Heavy Duty Liquid and Gaseous Fuel Emissions Database Test Results from Four Alternative Fuel Configurations of the Caterpillar 3406 Engine ORNL/Sub/86-SB195/1 (June 1990)

D. J. Waldman. Caterpillar, Inc., Technical Center, Peoria, III.

449 Federal Methanol Fleet Update

Proceedings Twenty-Seventh Automotive Technology Development Contractors'

Coordination Meeting, Dearborn, Mich., October 23-26, 1989 P-230, pp. 11-15

(Warrendale, Pa.: Society of Automotive Engineers, April 1990)

R. N. McGill. Oak Ridge National Laboratory, Oak Ridge, Tenn.

450 Alternative Fuels R\&D Needs Program Directions

Proceedings Twenty-Seventh Automotive Technology Development Contractors'

Coordination Meeting, Dearborn, Mich., October 23-26, 1989 P-230, pp. 7-9

(Warrendale, Pa.: Society of Automotive Engineers, April 1990)

R. L. Graves. Oak Ridge National Laboratory, Oak Ridge, Tenn.

451 Ignition Enhancement of the DDC Methanol Engine

Proceedings of the Twenty-Seventh Automotive Technology Development Contractors'

Coordination Meeting P-230, pp. 23-28 (Warrendale, Pa.: Society of Automotive

Engineers, Inc., April 1990)

P. M. Laing, R. E. Winsor. Detroit Diesel Corp., Detroit, Mich.

452 Heavy Duty Liquid and Gaseous Fuel Database Test Results from Four Alternative Configurations of the Caterpillar 3406 Engine

Proceedings of the Twenty-Seventh Automotive Technology Development Contractors'

Coordination Meeting P-230, pp. 29-41 (Warrendale, Pa.: Society of Automotive

Engineers, Inc., April 1990)

D. J. Waldman. Caterpillar, Inc., Peoria, III.

453 Photographic Visualization of the Ignition of Methanol in a Compression Ignition Engine

Proceedings of the Twenty-Seventh Automotive Technology Development Contractors'

Coordination Meeting P-230, pp. 17-22 (Warrendale, Pa.: Society of Automotive

Engineers, Inc., April 1990)

D. L. Abata. Michigan Technological University, Houghton, Mich.

454 Performance Comparisons of Insulated and Non-Insulated Diesel Engines Proceedings of the Twenty-Seventh Automotive Technology Development Contractors' Coordination Meeting P-230, pp. 75-80 (Warrendale, $\mathrm{Pa}$.: Society of Automotive Engineers, Inc., April 1990)

W. K. Cheng, V. W. Wong, F. Gao. Massachusetts Institute of Technology, Cambridge, Mass.

455 Experimental Heat Transfer Efforts with Thermal Barrier Materials at ORNL Proc. Workshop on Coatings for Advanced Heat Engines, Castine, Maine, August 5-

9,1990, pp. IV-53-IV-60 (Washington, D.C.: Department of Energy, 1990)

N. Domingo, M. R. Cates. Oak Ridge National Laboratory, Oak Ridge, Tenn. 
456 Low-Heat-Rejection Engine Research Status: Where Do We Go From

Here?

SAE Paper 900621, presented at the 1990 SAE International Congress and Exposition, February 26-March 2, 1990, Detroit, Michigan

C. S. Reddy. Union College, Schenectady, N.Y.

N. Domingo, R. L. Graves. Oak Ridge National Laboratory, Oak Ridge, Tenn.

457 Chemical Effect of Fuel Composition Changes on Emissions from a DI Diesel Engine. Final Report

ORNLSub/86-SB020/1 (December 1989)

T. A. Litzinger. The Pennsylvania State University, University Park, Pa.

458 Abnormal Combustion in a Methanol Fueled Engine

SAE paper no. 892162, presented at the 1989 SAE International Fuels and Lubricants Meeting and Exposition, September 1989, Baltimore, Md.

M. R. Swain, J. A. Blanco, M. N. Swain. University of Miami, Coral Gables, Fla.

459 Effects of Fuel/Air Mixture Preparation on Fuel Nitrogen Conversion in a Spark Ignition Engine

SAE paper no. 892161, presented at the 1989 SAE International Fuels and Lubricants Meeting and Exposition, September 1989, Baltimore, Md.

J. W. Hodgson. University of Tennessee, Knoxville, Tenn.

R. N. McGill. Oak Ridge National Laboratory, Oak Ridge, Tenn.

460 The Effect of Hydro Treatment of Coal-Derived Synthetic Fuels on DI Diesel Emissions and Performance

SAE paper no. 892132, presented at the 1989 SAE International Fuels and Lubricants Meeting and Exposition, September 1989, Baltimore, Md.

J. H. Palumbo, T. A. Litzinger. Pennsylvania State University, University Park, Pa.

461 Hydroprocessing of Direct Coal Liquefaction Product for Diesel Engine Fuel

SAE paper no. 892131, presented at the 1989 SAE International Fuels and Lubricants

Meeting and Exposition, September 1989, Baltimore, Md.

N. R. Sefer, J. Erwin. Southwest Research Institute, San Antonio, Texas

462 The Effect of Aromatics and Cycloparaffins on DI Diesel Emissions

SAE paper no. 892130, presented at the 1989 SAE International Fuels and Lubricants Meeting and Exposition, September 1989, Baltimore, Md.

C. T. Flanigan, T. A. Litzinger. Pennsylvania State University, University Park, Pa.

R. L. Graves. Oak Ridge National Laboratory, Oak Ridge, Tenn.

463 Thermal Barrier Effects on Performance and Emissions of a Methanol Fueled DI Engine

SAE paper no. 892163, presented at the 1989 SAE International Fuels and Lubricants Meeting and Exposition, September 1989, Baltimore, Md.

W. K. Kahl. Oak Ridge National Laboratory, Oak Ridge, Tenn.

464 Results from the Second Year of Operation of the Federal Methanol Fleet at Argonne National Laboratory

ORNL/TM-11230 (August 1989)

R. N. McGill, B. H. West. Oak Ridge National Laboratory, Oak Ridge, Tenn.

S. L. Hillis, J. W. Hodgson. University of Tennessee, Knoxville, Tenn. 
465 Results from the First Year of Operation of the Federal Methanol Fleet at Oak Ridge National Laboratory

ORNL/TM-11229 (July 1989)

R. N. McGill, B. H. West. Oak Ridge National Laboratory, Oak Ridge, Tenn.

S. L. Hillis, J. W. Hodgson. University of Tennessee, Knoxville, Tenn.

466 Fuel Nitrogen Conversion in a Spark Ignition Engine Part II: Effects of Fuel/Air Mixture Preparation ORNLSub/87-07685/1 (February 1989)

J. W. Hodgson. University of Tennessee, Knoxville, Tenn.

467 Analysis of the Combustion of Four Alternate Fuels in a Diesel Engine Using High Speed Photography. Final Report

ORNL/Sub/87-91333/1 (February 1989)

D. L. Abata, D. Masterson. Michigan Technological University, Houghton, Mich.

468 Evaluation of the Effects of Natural Gas Contaminants on Corrosion in Compressed Natural Gas Storage Systems-Phase II

ORNL/Sub/85-22025/1 (January 1989)

F. F. Lyle, Jr. Southwest Research Institute, San Antonio, Texas 


\section{MICROEMULSION FUELS}

469 Correlating Microemulsion Fuel Composition, Structure, and Combustion Properties

ORNL/TM-11248 (September 1989)

W. L. Griffith, A. L. Compere. Oak Ridge National Laboratory, Oak Ridge, Tenn.

470 Small Angle Scattering From Micelles of Potassium Salts of 18-Carbon Fatty Acids

Langmuir 5, pp. 1191-95 (1989)

J. S. Johnson, Jr., W. L. Griffith, A. L. Compere. Oak Ridge National Laboratory, Oak Ridge, Tenn.

471 Effect of Composition on Sizes of W/O Ethanolamine-Oleic Acid Microemulsions by Small-Angle Neutron Scattering

Langmuir 5(2), pp. 357-63 (1989)

E. Caponetti, R. Triolo, A. Lizzio. Istituto Chimica Fisica, University of Palermo, Palermo, Italy

W. L. Griffith, J. S. Johnson, Jr., A. L. Compere. Oak Ridge National Laboratory, Oak Ridge, Tenn.

472 Analysis of Small-Angle Scattering Patterns from Precipitating Alloys Physical Review B 39(7), pp. 4588-94 (1989)

R. Triolo, E. C. Caponetti. Istituto Chimica Fisica, University of Palermo, Palermo, Italy

S. Spooner. Oak Ridge National Laboratory, Oak Ridge, Tenn.

473 Opportunities for Improved Energy Recovery in Pulp Mills Alternative Energy Sources VIII. Proceedings of the Eighth Miami International Conference, Miami, Fla., December 14-16, 1987, 2, pp. 755-68 (Washington, D.C.: Hemisphere Press, 1989)

A. L. Compere, W. L. Griffith. Oak Ridge National Laboratory, Oak Ridge, Tenn.

T. W. Joyce. North Carolina State University, Raleigh, N.C. 



\section{INDUSTRIAL CHEMICAL HEAT PUMPS}

474 Materials Corrosion in Ammonia/Solid Heat Pump in Working Media ORNLTM-12004 (January 1992)

D F. Wilson, M. Howell, J. H. DeVan. Oak Ridge National Laboratory, Oak Ridge, Tenn.

475 Methods for Predicting Properties and Tailoring Salt Solutions for Industrial Processes

Technology 2002: Conference Proceedings, The Third National Technology Transfer Conference and Exposition, December 1-3, 1992, NASA-CP-3189 (Washington,

D.C.: National Aeronautics and Space Administration, 1992)

M. R. Ally. Oak Ridge National Laboratory, Oak Ridge, Tenn.

476 Refractive Indexes of Aqueous LiBr Solutions

J. Chem. Eng. Data 37, pp. 110-13 (1992)

A. Zaltash, M. R. Ally. Oak Ridge National Laboratory, Oak Ridge, Tenn.

477 Validation of a PC Based Program for Single Stage Absorption Heat Pump ORNL/TM-11923 (September 1991)

A Zaltash, M. R. Ally. Oak Ridge National Laboratory, Oak Ridge, Tenn.

478 Effect of Additives on the Film Heat Transfer Coefficients of $(\mathrm{Li}, \mathrm{K}, \mathrm{Na}) \mathrm{NO}_{3}$ and $\mathrm{LiBr}$ Aqueous Mixtures

Proceedings of the XVIII International Congress of Refrigeration, Montreal, Quebec, August 10-15, 1991, paper no. 52 (Paris: International Institute of Refrigeration, 1991) A. Zaltash, M. R. Ally, R. L. Linkous, R. H. Reiner. Oak Ridge National Laboratory, Oak Ridge, Tenn.

479 Densities and Refractive Indexes of Aqueous ( $\mathrm{Li}, \mathrm{K}, \mathrm{Na}) \mathrm{NO}_{3}$ Mixtures J. Chem. Eng. Data 36, pp. 209-13 (1991)

M. R. Ally, L. N. Klatt, A. Zaltash, R. L. Linkous. Oak Ridge National Laboratory, Oak Ridge, Tenn.

480 Measurements of Heat and Mass Transfer Coefficients During Absorption of Water Vapor by Lithium Bromide and $(\mathrm{Li}, \mathrm{K}, \mathrm{Na}) \mathrm{NO}_{3}$ Mixtures

Heat Pump Design, Analysis, and Application AES 26, pp. 83-90 (New York: American Society of Mechanical Engineers, 1991)

A. Zaltash, M. R. Ally, R. L. Linkous, L. N. Klatt. Oak Ridge National Laboratory, Oak Ridge, Tenn. 


\section{MATERIALS FOR ADVANCED INDUSTRIAL HEAT EXCHANGERS}

481 Product Technology and Market Assessment of Silicon Carbide Whisker Reinforced Alumina Heat-Exchanger Tubes

ORNL/Sub/86-SE793C/1 (October 1993)

R. O. Louffy, J. C. Withers, D. Chakravarti. Materials and Electrochemical Research Corporation, Tucson, Ariz.

482 Fabrication of Whisker-Toughened Alumina Tubes ORNL/Sub/86-SE793C (September 1993)

R. O. Loutfy. Materials and Electrochemical Research Corporation, Tucson, Ariz.

483 High-Temperature Corrosion of Ceramic-Ceramic Composites in a Waste Incinerator Environment ORNLTM-12212 (January 1993)

J. R. Keiser, J. I. Federer, T. J. Henson, D. L. Hindman. Oak Ridge National Laboratory, Oak Ridge, Tenn.

484 Development of a Zirconia-Mullite Based Ceramic for Recuperator Applications

ORNL/Sub/86-22044/2 (December 1992)

J. M. Gonzalez, GTE Products Corp., Towanda, Pa.

485 Rheology of Zirconia-Alumina Gelcasting Slurries

Proceedings of the Spring Meeting, Materials Research Society, San Francisco, April 27May 1, 1992, 271, pp. 269-75 (Pittsburgh: Materials Research Society, 1992)

A. Bleier, O. O. Omatete, C. G. Westmoreland. Oak Ridge National Laboratory, Oak Ridge, Tenn.

486 Corrosion of SiC and Oxide-Composite Ceramics by a Simulated SteamReformer Atmosphere

ORNL/TM-11828 (September 1991)

J. I. Federer, H. E. Kim, A. J. Moorhead. Oak Ridge National Laboratory, Oak Ridge, Tenn.

487 Corrosion Behavior of Continuous-Filament-Wound Ceramic Composite Tubes ORNLTM-11691 (May 1991)

J. I. Federer. Oak Ridge National Laboratory, Oak Ridge, Tenn.

488 Gelcast Reaction-Bonded Silicon Nitride Composites

Ceramic Engineering and Science Proceedings 12, proceedings of the 15th Annual Conference on Composites and Advanced Ceramic Materials, Cocoa Beach, Fla., January 13-16, 1991 (Westerville, Ohio: American Ceramic Society, 1991)

O. O. Omatete, T. N. Tiegs, A. C. Young. Oak Ridge National Laboratory, Oak Ridge, Tenn.

489 Construction and Testing of a Flue-Gas Corrosion Probe ORNL-6630 (August 1990)

J. I. Federer, J. A. McEvers. Oak Ridge National Laboratory, Oak Ridge, Tenn.

490 Design Methodology Needs for Fiber-Reinforced Ceramic Heat Exchangers

ORNL/TM-11012 (August 1990)

J. J. Blass, M. B. Ruggles. Oak Ridge National Laboratory, Oak Ridge, Tenn. 
491 Industrial Operating Experience of the GTE Ceramic Recuperator

ORNL/Sub/86-22044 (June 1990)

J. M. Gonzalez, J. L. Ferri. GTE Products Corp., Towanda, Pa.

W. J. Rebello. PAR Enterprises, Inc., Fairfax, Va.

492 Alumina-Base Coatings for Protection of SiC Ceramics J Mater. Eng. 12, pp. 141-49 (1990)

J. I. Federer. Oak Ridge National Laboratory, Oak Ridge, Tenn.

493 High-Temperature Corrosion of Heat Exchanger Materials Ceramics Transactions 10, pp. 425-43 (1990)

J. I. Federer. Oak Ridge National Laboratory, Oak Ridge, Tenn.

494 Selection of Corrosion Resistant Materials For Use In Molten Nitrate Salts ORNL/TM-11162 (October 1989)

P. F. Tortorelli, P. S. Bishop, J. R. DiStefano. Oak Ridge National Laboratory, Oak Ridge, Tenn.

\section{Extrusion of Alumina-Silicon Carbide Whisker Composites} ORNL/TM-10373 (October 1989)

M. A. Janney, E. S. Bomar, M. C. Vance. Oak Ridge National Laboratory, Oak Ridge, Tenn.

496 High-Temperature Corrosion of Metallic Alloys in an Oxidizing Atmosphere Containing $\mathrm{NaCl}$

ORNLTM-11029 (February 1989)

J. I. Federer. Oak Ridge National Laboratory, Oak Ridge, Tenn. 


\section{ADVANCED INDUSTRIAL MATERIALS}

497 Effects of Electronic and Recoil Processes in Polymers During Ion Implantation

J. Mater. Res. 9(4), p. 1043 (April 1994)

E. H. Lee, G. R. Rao, M. B. Lewis, L. K. Mansur. Oak Ridge National Laboratory, Oak

Ridge, Tenn.

498 Solid Solution Limits and Selected Mechanical Properties of the Quaternary L/2 Trialuminide Al-Ti-Mn-Mo

Scr. Metall. 30(8), p. 997 (April 15, 1994)

J. H. Schneibel. Oak Ridge National Laboratory, Oak Ridge, Tenn.

499 Characterization, Processing and Alloy Design of NiAl-Based Shape Memory Alloys

Mater. Charact. 32(3), p. 139 (April 1994)

E. P. George, C. T. Liu, J. A. Horton, C. J. Sparks. Oak Ridge National Laboratory, Oak

Ridge, Tenn.

M. Kao. Johnson Control, Inc., Milwaukee, Wis.

H. Kunsmann, T. King. Eaton Corporation, Milwaukee, Wis.

500 Site Occupation of Iron in Intermetallic NiAl

Appl. Surf. Sci. 76/77, p. 155 (March 1994)

A. J. Duncan, M. J. Kaufman. University of Florida, Gainesville, Fla.

C. T. Liu, M. K. Miller. Oak Ridge National Laboratory, Oak Ridge, Tenn.

501 Segregation of Interstitial Impurities in Single Crystal NiAl

Appl. Surf. Sci. 76/77, p. 160 (March 1994)

A. J. Duncan, M. J. Kaufman. University of Florida, Gainesville, Fla.

M. K. Miller. Oak Ridge National Laboratory, Oak Ridge, Tenn.

502 Effects of Alloying Additions on the Microstructures, Mechanical Properties and Weldability of FezAl-Based Alloys

Mater. Sci. Eng. 174(1), p. 59 (January 1994)

C. G. McKamey, P. J. Maziasz, G. M. Goodwin, T. Zacharia. Oak Ridge National Laboratory,

Oak Ridge, Tenn.

503 Homogeneous Reaction Rate Model for Hydrogen Production from IonIrradiated Polymers

J. Nucl. Mater. 208, pp. 61-72 (1994)

M. B. Lewis, E. H. Lee, L. K. Mansur. Oak Ridge National Laboratory, Oak Ridge, Tenn.

W. A. Coghlan. Grand Canyon University, Phoenix, Ariz.

504 Raman Scattering from Ion Implanted Diamond, Graphite and Polymers Phys. Rev. B 48(21), pp. 15540-51 (December 1, 1993)

E. H. Lee, L. K. Mansur. Oak Ridge National Laboratory, Oak Ridge, Tenn.

D. M. Hembree, Jr. Oak Ridge Y-12 Plant, Oak Ridge, Tenn.

G. R. Rao. Auburn University, Auburn, Ala.

5052 to $18 \mathrm{GHz}$ Broadband Microwave Heating Systems

Microwave Journal 36(11), p. 24 (November 1993)

R. J. Lauf, D. W. Bible. Oak Ridge National Laboratory, Oak Ridge, Tenn.

A. C. Johnson, C. A. Everleigh. Microwave Labs, Inc., Raleigh, N. C. 
506 Thermal Expansion Data on Several Iron- and Nickel-Aluminide Alloys Scr. Metall. et Mater. 29(8), p. $1043-48$ (October 15, 1993)

W. D. Porter, P. J. Maziasz. Oak Ridge National Laboratory, Oak Ridge, Tenn.

507 G-Values for Gas Production from lon-Irradiated Polystyrene J. Nucl. Mater. 203(3), p. 224 (September 1993)

M. B. Lewis, E. H. Lee. Oak Ridge National Laboratory, Oak Ridge, Tenn.

508 Weld Solidification Cracking in Cast Ni3Al Alloys

Scr. Metall. et Mater. 28(11), pp. 1305-10 (June 1, 1993)

M. L. Santella. Oak Ridge National Laboratory, Oak Ridge, Tenn.

509 Alloying Effects on Mechanical and Metallurgical Properties of NiAl ORNL/TM-12200 (June 1993)

S. L. Lee, J. A. Horton, E. H. Lee, E. P. George. Oak Ridge National Laboratory, Oak Ridge, Tenn.

510 Ordered Intermetallic Alloys. Part II: Silicides, Trialuminides, and Others JOM 45(6), p. 28 (June 1993)

C. T. Liu. Oak Ridge National Laboratory, Oak Ridge, Tenn.

K. S. Kumar. Martin Marietta Laboratories, Baltimore, Md.

511 Ordered Intermetallic Alloys. Part l: Nickel and Iron Aluminides JOM 45(5), p. 38 (May 1993)

C. T. Liu. Oak Ridge National Laboratory, Oak Ridge, Tenn.

K. S. Kumar. Martin Marietta Laboratories, Baltimore, Md.

512 Electrical Resistivity of Ni0.8M00.2: Explanation of Anomalous Behavior in Short-Range Ordered Alloys

Phys. Rev. Lett. 70(21), pp. 3311-14 (May 24, 1993)

D. M. C. Nicholson. Oak Ridge National Laboratory, Oak Ridge, Tenn.

R. H. Brown. Luther College, Decorah, lowa

513 Microstructural Effects on Surface Mechanical Properties of Ion Implanted Polymers

J. Mater. Res. 8(4), pp. 927-33 (April 1993)

G. R. Rao. Auburn University, Auburn, Ala.

Z. L. Wang, E. H. Lee. Oak Ridge National Laboratory, Oak Ridge, Tenn.

514 Application of Local Selfconsistency to Alloy Phase Stability Buil. Am. Phys. Soc. 38(1), p. 255 (March 1993)

D. M. C. Nicholson, G. M. Stocks, W. A. Shelton. Oak Ridge National Laboratory, Oak

Ridge, Tenn.

W. M. Temmerman, Z. Szotek. Daresbury Laboratory, Daresbury, Cheshire, United

Kingdom

515 Alloy Development of FeAl Aluminide Alloys for Structural Use in Corrosive Environments ORNL/TM-12199 (February 1993)

C. T. Liu, V. K. Sikka, C. G. McKamey. Oak Ridge National Laboratory, Oak Ridge, Tenn.

516 Hardness Measurements of Art-Beam Treated Polyimide by DepthSensing Uitra Low Load Indentation J. Mater. Res. 8(2), pp. 377-87 (February 1993)

E. H. Lee, W. C. Oliver, L. K. Mansur. Oak Ridge National Laboratory, Oak Ridge, Tenn. Y. Lee. Korea Academy of Industrial Technology, Seoul, Korea 
517 Calculation of the Electronic Properties of Ni-P Amorphous Alloys

Phys. Rev. B 47(1), pp. 107-14 (January 1, 1993-I)

H. Yang, J. C. Swihart. Indiana University, Bloomington, Ind.

D. M. Nicholson. Oak Ridge National Laboratory, Oak Ridge, Tenn.

R. H. Brown. Luther College, Decorah, lowa

518 Chemical Vapor Infiltration of $\mathrm{TiB}_{2}$ Composites

ORNLTM-12214 (January 1993)

T. M. Besmann, J. H. Miller, K. C. Cooley, R. A. Lowden, T. L. Starr. Oak Ridge National Laboratory, Oak Ridge, Tenn.

$519 \mathrm{Ni}_{3}$ and Its Alloys

Intermetallic Compounds: Principles and Applications, ed. J. H. Westbrook and R. L.

Fleischer (Chichester; New York: Wiley, 1993)

C. T. Liu. Oak Ridge National Laboratory, Oak Ridge, Tenn.

520 Weld Solidification Cracking in Cast Ni3Al Alloys

Scr. Metall. et Mater. 28, pp. 1305-10 (1993)

M. L. Santella. Oak Ridge National Laboratory, Oak Ridge, Tenn.

521 Ion Beam Application for Improved Polymer Surface Properties Nucl. Instrum. Methods Phys. Res. B 74, pp. 326-30 (1993)

E. H. Lee, M. B. Lewis, L. K. Mansur. Oak Ridge National Laboratory, Oak Ridge, Tenn. G. R. Rao. Auburn University, Auburn, Ala.

522 High Temperature Fracture Toughness of Ni3Al Alloy IC-396M pp. 118590 in Proceedings Fall Meeting, Materials Research Society, Boston, November 30-December 4, 1992 (Pittsburgh: Materials Research Society, 1993)

D. J. Alexander. Oak Ridge National Laboratory, Oak Ridge, Tenn.

523 Recent Advances in Ordered Intermetallics

pp. 310 in Proceedings Fall Meeting, Materials Research Society, Boston, November $30-$ December 4, 1992, Symposium L on High Temperature Intermetallic Alloys V, 288

(Pittsburgh: Materials Research Society, 1993)

C. T. Liu. Oak Ridge National Laboratory, Oak Ridge, Tenn.

524 Some Effects of Composition and Microstructure on the $B 2 \leftrightarrow D O_{3}$ Ordered Phase Transition in FezAl Alloys

pp. 209-15 in Proceedings Fall Meeting, Materials Research Society, Boston, November 30-December 4, 1992, Symposium L on High Temperature Intermetallic Alloys V, 288

(Pittsburgh: Materials Research Society, 1993)

P. J. Maziasz, C. G. McKamey, O. B. Cavin, C. R. Hubbard, T. Zacharia. Oak Ridge National Laboratory, Oak Ridge, Tenn.

525 Effects of Minor Alloying Elements on the Welding Behavior of FeAl Alloys for Structural and Weld-Overlay Cladding Applications Scr. Metall. et Mater. 27(12), pp. 1835-40 (December 15, 1992)

P. J. Maziasz, G. M. Goodwin, C. T. Liu, S. A. David. Oak Ridge National Laboratory, Oak Ridge, Tenn. 
526 Chemical Vapor Deposition of Refractory Metals and Ceramics II: Symposium held December 4-6, 1991, Boston, Massachusetts Materials Research Society Symposium Proceedings, 250 (Pittsburgh: Materials Research Society, 1992)

T. M. Besmann, ed. Oak Ridge National Laboratory, Oak Ridge, Tenn.

B. M. Gallois, ed. Stevens Institute of Technology, Hoboken, N.J.

J. W. Warren, ed. Composite Innovation Corp., Woodland Hills, Calif.

\section{Multikilowatt Variable Frequency Microwave Furnace}

Proceedings, Spring Meeting, Materials Research Society, San Francisco, April 27-May

1, 1992, 269, pp. 77-81 (Pittsburgh: Materials Research Society, 1992)

D. W. Bible, R. J. Lauf. Oak Ridge National Laboratory, Oak Ridge, Tenn.

C. A. Everleigh. Microwave Laboratories, Inc., Raleigh, N. C.

528 Rheology of Zirconia-Alumina Gelcasting Slurries

Proceedings, Spring Meeting, Materials Research Society, San Francisco, April 27-May

1, 1992; 271, pp. 269-75 (Pittsburgh: Materials Research Society, 1992)

A. Bleier, O. O. Omatete, C. G. Westmoreland. Oak Ridge National Laboratory, Oak

Ridge, Tenn.

529 Characterization of the Phase Transformations in the Shape Memory Alloy $\mathrm{Ni}-36$ atm \% Al

Proceedings, Fall Meeting, Materials Research Society, Boston, December 2-6, 1992

246, pp. 61-66 (Pittsburgh: Materials Research Society, 1992)

J. A. Horton, E. P. George, C. J. Sparks, O. B. Cavin. Oak Ridge National Laboratory, Oak Ridge, Tenn.

M. Y. Kao, P. Thoma. Johnson Controls, Inc., Milwaukee, Wis.

530 Microwave Processing of Ceramics: Guidelines Used at the Oak Ridge National Laboratory

Proceedings, Spring Meeting, Materials Research Society, San Francisco, April 27-May

1, 1992, 269, pp. 173-85 (Pittsburgh: Materials Research Society, 1992)

M. A. Janney, H. D. Kimrey, J. O. Kiggans. Oak Ridge National Laboratory, Oak Ridge, Tenn.

531 Microwave Sintering of Multilayer Ceramic Capacitors

Proceedings, Spring Meeting, Materials Research Society, San Francisco, April 27-May

1, 1992, 269, pp. 223-29 (Pittsburgh: Materials Research Society, 1992)

R. J. Lauf, C. Hamby. Oak Ridge National Laboratory, Oak Ridge, Tenn.

C. E. Holcombe. Y-12 Plant, Oak Ridge, Tenn.

532 Elevated-Temperature Environmental Embrittlement and Alloy Design of Li2 Ordered Intermetallics

Mater. Sci. Eng. A153, pp. 538-47 (1992)

M. Takeyama. National Research Institute for Metals, Tokyo, Japan

C. T. Liu. Oak Ridge National Laboratory, Oak Ridge, Tenn. 
533 First Principles Theory of Alloy Phase Stability. Ordering and PreMartensitic Phenomena in Beta-Phase NiAl

Proceedings, NATO Advanced Research Workshop on Ordered Intermetallics-Physical Metallurgy and Mechanical Behaviour, Irsee, Germany, June 23-29, 1991, pp. 15-36

(The Netherlands: Klūwer Publishers, 1992)

G. M. Stocks, W. A. Shelton, D. M. Nicholson. Oak Ridge National Laboratory, Oak Ridge, Tenn.

F. J. Pinski. University of Cincinnati, Cincinnati, Ohio

B. Ginatempo. University of Messina, Messina, Italy

A. Barbieri, B. L. Gyortfy. University of Bristol, Bristol, Great Britain

D. D. Johnson. Sandia National Laboratory, Livermore, Calif.

J. B. Staunton. University of Warwick, Coventry, Great Britain

P. E. A. Turchi, M. Sluiter. Lawrence Livermore National Laboratory, Livermore, Calif.

534 Cracking Behavior of FeAl (40 at. \% Al) Alloys During Cutting Operations Scr. Metall. 26, pp. 1669-74 (1992)

P. A. Ferguson. North Carolina State University, Raleigh, N.C.

C. T. Liu. Oak Ridge National Laboratory, Oak Ridge, Tenn.

535 The Role of Microscopy in the Alloy Design of Ni- and Fe-Based Aluminides

Proceedings of the 50th Annual Meeting of the Electron Microscope Society of America, Boston, August 16-21, 1992, pp. 168-69 (San Francisco Press, 1992)

J. A. Horton. Oak Ridge National Laboratory, Oak Ridge, Tenn.

536 Multiple-Ion Irradiations: Facility Review and Highlights of Applications to Metals, Ceramics, and Polymers

Proceedings of the 16th International Symposium on Effects of Radiation on Materials, Denver, June 21-22, 1992 (Philadelphia, Pa.: American Society for Testing and Materials, 1992)

L. K. Mansur, E. H. Lee, M. B. Lewis, S. J. Zinkle. Oak Ridge National Laboratory, Oak

Ridge, Tenn.

537 Multiple-Scattering Theory and the Quadratic Korringa-Kohn-Rostoker Method

Phys. Rev. B 44(16), pp. 8467-72 (October 15, 1991)

J. S. Faulkner, E. A. Horvath. Florida Atlantic University, Boca Raton, Fla.

D. M. Nicholson. Oak Ridge National Laboratory, Oak Ridge, Tenn.

538 Models for Heat Transport Through Assemblies of Uniform-Diameter Hollow Spheres

ORNLTM-11397 (April 1991)

D. W. Yarbrough, D. L. McElroy, F. J. Weaver. Oak Ridge National Laboratory, Oak Ridge, Tenn.

539 Ground State Properties and Magnetism in Substitutionally Disordered Fe 1-xCrx Alloys

Proceedings of the Spring Meeting, Materials Research Society, San Francisco, April 18-

20, 1990 186, pp. 27-31 (Pittsburgh: Materials Research Society, 1991)

W. A. Shelton, Jr. Computational Physics, Inc., Annandale, Va.

F. J. Pinski. University of Cincinnati, Cincinnati, Ohio

D. D. Johnson. Sandia National Laboratory, Livermore, Calif.

D. M. Nicholson, G. M. Stocks. Oak Ridge National Laboratory, Oak Ridge, Tenn. 
540 Crystal Growth and Deformation Behavior of TiAl Aluminides ORNLTM-11159 (April 1990)

B. F. Oliver, B. Y. Huang. University of Tennessee, Knoxville, Tenn.

W. C. Oliver. Oak Ridge National Laboratory, Oak Ridge, Tenn.

541 Energy Applications of High-Temperature Superconductivity ER-6682, Volumes 1-2 (Palo Alto, Calif.: Electric Power Research Institute, 1990)

S. J. Dale. Oak Ridge National Laboratory, Oak Ridge, Tenn.

S. M. Wolf. Office of Conservation and Renewable Energy, U.S. Department of Energy, Washington, D.C.

T. R. Schneider. Electric Power Research Institute, Palo Alto, Calif.

542 Brittle Fracture and Grain Boundary Chemistry of Microalloyed NiAl J. Mater. Res., pp. 754-62 (1990)

E. P. George, C. T. Liu. Oak Ridge National Laboratory, Oak Ridge, Tenn.

543 The Effect of Processing on the Toughness of a Nickel Aluminide Alloy Scripta Met. 24, pp. 845-50 (1990)

D. J. Alexander. Oak Ridge National Laboratory, Oak Ridge, Tenn.

544 Brittle Fracture and Grain Boundary Chemistry of Microalloyed NiAI

J. Mater. Res. 5, p. 754 (1990)

E. P. George, C. T. Liu. Oak Ridge National Laboratory, Oak Ridge, Tenn.

545 Temperature and Pressure Effects for Oxygen Adsorption and Oxidation of Ni3Al Alloyed with Chromium and Zirconium

Surface Science 225, pp. 195-205 (1990)

A. M. Venezia, C. M. Loxton. University of Illinois Urbana-Champaign, Champaign, III.

J. A. Horton. Oak Ridge National Laboratory, Oak Ridge, Tenn.

546 Superplasticity in an NisAl Base Alloy with 8 wt \% Cr J. Mater. Sci. 25(7), pp. 3142-48 (1990)

A. Choudhury, A. K. Mukherjee. University of California, Davis, Calif.

V. K. Sikka. Oak Ridge National Laboratory, Oak Ridge, Tenn.

547 Ab Initio Study of the Cu-Pd One-Dimensional Long Period Superstructure Phase Diagram

Acta Metall. Mater. 38(11), pp. 2299-2308 (1990)

G. Ceder, D. de Fontaine. University of California, Berkeley, Calif.

H. Dreysse. Universite de Nancy, France

D. M. Nicholson, G. M. Stocks. Oak Ridge National Laboratory, Oak Ridge, Tenn.

B. L. Gyorffy. University of Bristol, United Kingdom

548 High Critical Current Densities in $\mathrm{YBa}_{2} \mathrm{Cu}_{3} \mathrm{O}_{7-\mathrm{x}}$ Films on Polycrystalline Zirconia

Applied Physics Letters 57, pp. 1164 (1990)

D. P. Norton, D. H. Lowndes, J. D. Budai, D. K. Christen. Oak Ridge National Laboratory,

Oak Ridge, Tenn.

E. C. Jones. University of Tennessee, Knoxville, Tenn.

K. W. Lay, J. E. Tksczyk. General Electric Company, Schenectady, N.Y. 
549 Y-Ba-Cu-O Thin Films Grown on Rigid and Flexible Polycrystalline YttriaStabilized Zirconia by Pulsed Laser Ablation

J. Applied Physics 68, pp. 223-27 (1990)

D. P. Norton, D. H. Lowndes, J. D. Budai, D. K. Christen. Oak Ridge National Laboratory, Oak Ridge, Tenn.

J. W. McCamy, E. C. Jones. University of Tennessee, Knoxville, Tenn.

T. D. Ketcham, D. St. Julien. Corning, Corning, N.Y.

K. W. Lay, J. E. Tksczyk. General Electric Company, Schenectady, N.Y.

550 Selection of Corrosion-Resistant Materials for Use in Molten Nitrate Salts ORNL/TM-11162 (October 1989)

P. F. Tortorelli, P. S. Bishop, J. R. DiStefano. Oak Ridge National Laboratory, Oak Ridge, Tenn.

551 An Investigation of Elastic Guided Waves for Ceramic Joint Evaluation ORNL/TM-10931 (October 1989)

W. A. Simpson, Jr., R. W. McClung. Oak Ridge National Laboratory, Oak Ridge, Tenn.

552 High-Temperature Ordered Intermetallic Alloys III

ORNL/M-924 (August 1989)

C. T. Liu. Oak Ridge National Laboratory, Oak Ridge, Tenn.

A. I. Taub. General Electric Corp., Schenectady, N.Y.

N. S. Stoloff. Rensselaer Polytechnic Institute, Troy, N.Y.

C. C. Koch. North Carolina State University, Raleigh, N.C.

553 Alloy Development and Mechanical Properties of Nickel Aluminide (Ni3Al) Alloys

ORNL-6483 (August 1989)

C. T. Liu, V. K. Sikka, J. A. Horton, E. H. Lee. Oak Ridge National Laboratory, Oak Ridge,

Tenn.

554 Materials by Design: Assessment of Theoretical and Experimental Tools

for Applied Research and Exploratory Development in Certain Energy

Technologies

ORNL/Sub/86-00210/1 (February 1989)

R. W. Broach, R. A. Eades. Allied-Signal Engineered Materials, Des Plaines, III.

J. J. Low. University of Wisconsin, Milwaukee, Wis.

T. L. Barr. Consultant to ORNL, Toulumne, Calif.

J. W. Frazer. Oak Ridge National Laboratory, Oak Ridge, Tenn.

J. A. Carpenter, Jr. National Institute for Standards and Technology, Gaithersburg, Md.

555 Inorganic and Biomass-Derived Plastics: Viable Economic Alternatives to Petrochemical Plastics?

ORNLTM-10880 (February 1989)

T. R. Curlee. Oak Ridge National Laboratory, Oak Ridge, Tenn.

556 The Feasibility of Recycling Plastic Wastes: An Update

Journal of Environmental Systems 18, pp. 193-212 (1989)

T. R. Curlee. Oak Ridge National Laboratory, Oak Ridge, Tenn.

557 Microstructures of Ni3Al Alloys as a Function of $\mathrm{Cr}$ and Al Levels Proceedings of the 47th Annual Meeting, Electron Microscopy Society of America, San Antonio, Texas, August 6-11, 1989, pp. 306-307 (San Francisco: San Francisco Press, Inc., 1989)

J. A. Horton. Oak Ridge National Laboratory, Oak Ridge, Tenn. 
558 Fabrication and Mechanical Properties of $\mathrm{Ni}_{3} \mathrm{Al}-\mathrm{Al}_{2} \mathrm{O}_{3}$ Composites High-Temperature Ordered Intermetallic Alloys III: Symposium Held November 29December 1, 1988, Boston, Massachusetts. Materials Research Society Symposia Proceedings 133, ed. C. T. Liu et al., pp. 607-14 (Pittsburgh: Materials Research Society, 1989)

C. G. McKamey, J. A. Horton, T. N. Tiegs, E. K. Ohriner. Oak Ridge National Laboratory, Oak Ridge, Tenn.

G. L. Povirk. Brown University, Providence, R.I.

559 Structure Maps and Phase Stability in AlTi3 Alloyed with Rare-Earth Elements

High-Temperature Ordered Intermetallic Alloys III: Symposium Held November 29December 1, 1988, Boston, Massachusetts. Materials Research Society Symposia Proceedings 133, ed. C. T. Liu et al., pp. 37-43 (Pittsburgh: Materials Research Society, 1989)

C. T. Liu, J. A. Horton. Oak Ridge National Laboratory, Oak Ridge, Tenn.

D. G. Pettifor. Imperial College of Science and Technology, London, England

560 The Development of Alloys Based on NizSi

High-Temperature Ordered Intermetallic Alloys III: Symposium Held November 29December 1, 1988, Boston, Massachusetts. Materials Research Society Symposia Proceedings 133, ed. C. T. Liu et al., pp. 397-402 (Pittsburgh: Materials Research Society, 1989)

W. C. Oliver. Oak Ridge National Laboratory, Oak Ridge, Tenn.

561 Applications of the Quadratic Korringa-Kohn-Rostoker Band-Theory Mothod

Phys. Rev. B 39, pp. 8187-92 (1989)

D. M. Nicholson. Oak Ridge National Laboratory, Oak Ridge, Tenn.

J. S. Faulkner. Florida Atlantic University, Boca Raton, Fla.

562 Analysis of Heat-Affected Zone Cracking in Ni3Al Alloy Welds by Computer Modeling of Thermal Stresses

Welding J. 68(1), pp. 19s-27s (1989)

M. L. Santella, S. A. David. Oak Ridge National Laboratory, Oak Ridge, Tenn.

M. C. Maguire. Colorado School of Mines, Golden, Colo. 


\section{TRIBOLOGY}

563 Fast Fourier Transform Analysis of Computer-Acquired Friction Data Trib. Trans. 37(1), p. 201 (January 1994)

C. S. Yust. Oak Ridge National Laboratory, Oak Ridge, Tenn.

564 Tribological Behavior of Whisker Reinforced Ceramic Composite Materials Friction and Wear of Ceramics, ed. S. Jahanmir, p. 199 (New York: Marcel Dekker, 1994) C. S. Yust. Oak Ridge National Laboratory, Oak Ridge, Tenn.

565 Development of a Theory of the Wear of Ceramics ORNL/Sub/93-07802 (October 1993)

W. O. Winer, R. S. Cowan. Georgia Institute of Technology, Atlanta, Georgia

566 Advanced Tribomaterials for the 90's and Beyond

Proceedings of the Annual Automotive Technology Development Contractors'

Coordination Meeting 1992, pp. 165-70 (Warrendale, Pa.: Society of Automotive

Engineers, May 1993)

P. J. Blau. Oak Ridge National Laboratory, Oak Ridge, Tenn.

567 Friction Microprobe Investigation of Particle Layer Effects on Sliding Friction

Wear 162, p. 102 (1993)

P. J. Blau. Oak Ridge National Laboratory, Oak Ridge, Tenn.

568 A Retrospective Survey of the Use of Simulative Laboratory Tests to Address Internal Combustion Engine Tribology Problems

Wear Test Selection for Design and Application, ed. A. W. Ruff and R. G. Bayer, p. 133

(Philadelphia: American Society for Testing and Materials, 1993)

P. J. Blau. Oak Ridge National Laboratory, Oak Ridge, Tenn.

569 A Comparison of Three Microindentation Hardness Scales at Low and Ultra-Low Loads

Mater. Charact. 30, pp. 287-93 (1993)

P. J. Blau, J. R. Keiser, R. L. Jackson. Oak Ridge National Laboratory, Oak Ridge, Tenn.

570 Relating Laboratory Friction Coefficient Values to Practical Applications Proceedings of the Annual Automotive Technology Development Contractors' Coordination Meeting 1991 P-256, pp. 571-77 (Warrendale, Pa.: Society of Automotive Engineers, June 1992)

P. J. Blau. Oak Ridge National Laboratory, Oak Ridge, Tenn.

571 Wear Mode Transition in a Silicon Nitride-Silicon Carbide Whisker Composite

Proceedings of the Annual Automotive Technology Development Contractors' Coordination Meeting 1991 P-256, pp. 579-86 (Warrendale, Pa.: Society of Automotive Engineers, June 1992)

C. S. Yust. Oak Ridge National Laboratory, Oak Ridge, Tenn.

572 Wear-Resistant Materials

Advanced Materials and Processes Technological Forecast Issue, pp. 25-26 (January 1990)

P. J. Blau. Oak Ridge National Laboratory, Oak Ridge, Tenn. 
573 Sliding Friction and Wear Behavior of Nickel Aluminide Alloys

Trib. Internationa/ 23(4), pp. 226-34 (1990)

P. J. Blau, C. E. DeVore. Oak Ridge National Laboratory, Oak Ridge, Tenn.

574 Friction Microprobe Studies of Composite Surfaces

Tribology of Composite Materials, pp. 59-68 (Materials Park, Ohio: ASM International, 1990)

P. J. Blau. Oak Ridge National Laboratory, Oak Ridge, Tenn.

575 Friction and Wear of Whisker-Reinforced Ceramic Composite Materials Tribology of Composite Materials, pp. 25-33 (Materials Park, Ohio: ASM International, 1990)

C. S. Yust. Oak Ridge National Laboratory, Oak Ridge, Tenn.

576 Morphological Aspects of the Friction of Hot-Filament Grown Diamond Thin Films

Mechanics of Coatings, pp. 399-408 (Elsevier Publ., 1990)

P. J. Blau, C. S. Yust, L. J. Heatherly, R. E. Clausing. Oak Ridge National Laboratory, Oak Ridge, Tenn.

577 Elastic Behavior of Coated Rough Surfaces

Mechanics of Coatings, pp. 157-68 (Elsevier Publ., 1990)

J. I. McCool. MRC-SKF Aerospace, King of Prussia, Pa.

578 A Study of the Tribological and Surface Micromechanical Properties of $\mathrm{YBa}_{2} \mathrm{Cu}_{3} \mathrm{O}_{7-x}$. Final Report

ORNLTM-11053 (July 1989)

P. J. Blau, C. E. DeVore, D. F. Wilson, J. R. Keiser. Oak Ridge National Laboratory, Oak

Ridge, Tenn.

579 Friction and Wear Transitions of Materials: Break-in, Run-in, and Wear-in Park Ridge, N.J.: Noyes Publications, 1989

P. J. Blau. Oak Ridge National Laboratory, Oak Ridge, Tenn.

580 The Units of Wear Revisited

Lubrication Engineering 45, p. 609 (1989)

P. J. Blau. Oak Ridge National Laboratory, Oak Ridge, Tenn.

581 Temperature Effects on the Break-In of Nickel Aluminide Alloys Proceedings International Conference on Wear of Materials, Denver, Colo., April 8-11, 1989, ASME Book No. H0456A, Vol. 1, pp. 305-12 (New York: American Society of Mechanical Engineers, 1989)

P. J. Blau, C. E. DeVore. Oak Ridge National Laboratory, Oak Ridge, Tenn.

582 Interpretations of the Sliding Friction Break-In Curves of AluminaAluminum Couples Wear 129, pp. 81-92 (1989)

P. J. Blau, C. E. DeVore. Oak Ridge National Laboratory, Oak Ridge, Tenn. 


\title{
ENERGY-RELATED INVENTIONS PROGRAM
}

\author{
583 A Comparison Group Analysis of DOE's Energy-Related Inventions \\ Program \\ ORNL/CON-365 (June 1993)
}

M. A. Brown, T. R. Curlee, S. R. Elliott, C. A. Franchuk. Oak Ridge National Laboratory, Oak Ridge, Tenn.

584 Government Promotion of Energy Innovations: An Evaluation of the Energy-Related Inventions Program

Policy Studies Journal 20(1), pp. 87-101 (1992)

M. A. Brown. Oak Ridge National Laboratory, Oak Ridge, Tenn.

C. R. Wilson. University of Tennessee, Knoxville, Tenn.

585 The Energy-Related Inventions Program: A Decade of Commercial

Progress

ORNL/CON-339 (December 1991)

M. A. Brown, C. A. Franchuk. Oak Ridge National Laboratory, Oak Ridge, Tenn.

C. R. Wilson. University of Tennessee, Knoxville, Tenn.

586 Guidelines for Successfully Transferring Government-Sponsored Innovations

Research Policy 20(2): pp. 121-43 (April 1991)

M. A. Brown, L. G. Berry, R. K. Goel. Oak Ridge National Laboratory, Oak Ridge, Tenn.

587 The Energy-Related Inventions Program: Commercial Progress of Participants Through 1988

ORNL/CON-301 (May 1990)

M. A. Brown. Oak Ridge National Laboratory, Oak Ridge, Tenn.

C. R. Wilson. University of Tennessee, Knoxville, Tenn.

588 The Cost of Cómmercializing Energy Inventions

Research Policy 19(2), pp. 147-55 (1990)

M. A. Brown. Oak Ridge National Laboratory, Oak Ridge, Tenn.

589 Promoting the Commercialization of Energy Innovations: An Evaluation of the Energy-Related Inventions Program

Proceedings of the National Energy Program Evaluation Conference, Chicago, August 23-25, 1989, pp. 33-38 (Argonne, III.: Argonne National Laboratory, August 1989)

M. A. Brown. Oak Ridge National Laboratory, Oak Ridge, Tenn.

590 Commercializing Government-Sponsored Innovations: Twelve Successful Buildings Case Studies ORNLCON-275 (January 1989)

M. A. Brown, L. G. Berry, R. K. Goel. Oak Ridge National Laboratory, Oak Ridge, Tenn. 



\section{POWER SYSTEMS TECHNOLOGY}

591 Detection of $S_{2} F_{10}$ Produced by a Single Spark Discharge in $S_{6}$

J. Appl. Phy. 74(3), pp. 2103-5 (August 1993)

I. Sauers. Oak Ridge National Laboratory, Oak Ridge, Tenn.

S. M. Mahajan. Tennessee Technological University, Cookeville, Tenn.

592 Investigation of $S_{2} F_{10}$ Production and Mitigation In Compressed SF6Insulated Power Systems

IEEE Electrical Insulation Magazine 9(3), pp. 29-40 and 51 (May/June 1993)

D. R. James, ed., I. Sauers, G. D. Griffin. Oak Ridge National Laboratory, Oak Ridge, Tenn.

R. J. Van Brunt, J. K. Olthoff, K. L. Stricklett. National Institute of Standards and

Technology, Gaithersburg, Md.

F. Y. Chu, J. R. Robins, H. D. Morrison. Ontario Hydro Research Division, Toronto, Ontario

593 Geomagnet/c Storm Environments and Effects on Electrical Systems Proceedings 10th International Zurich Symposium and Technical Exhibition on

Electromagnetic Compatibility, Zurich, Switzerland, March 9-11, 1993, pp. 105-110

(Zurich: ETH Zentrum, March 1993)

P. R. Barnes. Oak Ridge National Laboratory, Oak Ridge, Tenn.

F. M. Tesche. Consultant to Oak Ridge National Laboratory, Oak Ridge, Tenn.

594 Electromagnetic Pulse Research on Electric Power Systems: Program Summary and Recommendations

ORNL-6708 (January 1993)

P. R. Bames, B. W. McConnell, J. W. Van Dyke. Oak Ridge National Laboratory, Oak

Ridge, Tenn.

F. M. Tesche, E. F. Vance. Consultants to Oak Ridge National Laboratory, Oak Ridge, Tenn.

595 Recommended Englneering Practice to Enhance the EMIEMP Immunity of Electric Power Systems

ORNL/Sub/91-SG913/1 (December 1992)

C. L. Wagner. Department of Energy, Washington, D. C.

W. E. Feero. Electric Research and Management, Inc., State College, Pa.

596 Proceedings, Workshop on Real-Time Control and Operation of Electric Power Systems, November 19-21, 1991, Denver, Colorado

CONF-9111173 (Oak Ridge, Tenn.: Oak Ridge National Laboratory, July 1992)

D. T. Rizy, ed. Oak Ridge National Laboratory, Oak Ridge, Tenn.

W. E. Myers, ed. Bonneville Power Administration, Portland, Ore.

L. E. Eilts, C. L. Clemans. Western Area Power Administration, Golden, Colo.

597 Experimental Investigation of Steep-Front, Short Duration (SFSD) Surge Effects on Power Systems Components

ORNL/Sub/87-91345 (May 1992)

D. B. Miller. Mississippi State University, Mississippi State, Miss.

598 Mitigation of Magnetohydrodynamic Electromagnetic Pulse (MHD-EMP) Effects from Commerclal Electric Power Systems ORNL-6709 (March 1992)

P. R. Bames. Oak Ridge National Laboratory, Oak Ridge, Tenn.

F. M. Tesche, E. F. Vance. Consultants to Oak Ridge National Laboratory, Oak Ridge, Tenn. 
599 HEMP-Induced Transients in Electric Power Substations ORNL/Sub/88-SC863 (February 1992)

C. M. Wiggins, D. E. Thomas, T. M. Salas. BDM International Inc., Albuquerque, N. Mex.

600 An Approach to Metering and Network Modeling Proceedings of the American Power Conference 54-II, pp. 1068-74 (Chicago: Illinois Institute of Technology, 1992)

M. M. Adibi. IRD Corporation, Bethesda, Md.

K. A. Clements. Worcester Polytechnic Institute, Worcester, Mass.

R. J. Kafka. Potomac Electric Power Company, Washington, D. C.

J. P. Stovall. Oak Ridge National Laboratory, Oak Ridge, Tenn.

601 Transient Electric and Magnetic Fleids Assoclated with Establishing a Finite Electrostatic Dipole, Revisited

IEEE Transactions on Electromagnetic Compatibility 33(4), pp. 312-20 (November 1991)

M. Rubinstein, M. A. Uman. University of Florida, Gainesville, Fla.

602 Maintaining Electric Power System Performance: Preparing for the Year 2020 Research Needs

ORNL-6678 (November 1991)

S. J. Dale, J. P. Stovall. Oak Ridge National Laboratory, Oak Ridge, Tenn.

K. W. Klein. Department of Energy, Washington, D. C.

603 Electric Utility Industry Experlence with Geomagnetic Disturbances ORNL-6665 (September 1991)

P. R. Barnes, D. T. Rizy, B. W. McConnell. Oak Ridge National Laboratory, Oak Ridge, Tenn.

F. M. Tesche. Consultant to Oak Ridge National Laboratory, Oak Ridge, Tenn.

E. R. Taylor, Jr. ABB Power Systems, Inc., Pittsburgh, Pa.

604 EMP Research on Electric Power Systems. Program Update ORNLM-1392 (May 1991)

P. R. Bames. Oak Ridge National Laboratory, Oak Ridge, Tenn.

605 Assessment of Conducting Polymer Applications in Power Equipment Technology

ORNL/SUb/87-SA681/1 (May 1991)

K. F. Schoch, Jr., A. I. Bennett, R. R. Burghardt, A. H. Cookson, H. E. Saunders, J. D. B. Smith. Westinghouse Electric Corp., Pittsburgh, Pa.

W. N. Kennedy. ABB Power Transmission \& Distribution Co., Pittsburgh, Pa.

T. V. Oommen. ABB Power Transmission \& Distribution Co., Sharon, Pa.

R. E. Voshall. Gannon University, Erie, Pa.

E. M. Fort. Westinghouse Electric Corp., Orlando, Fla.

B. Robbins. Reynolds Metals Co., Richmond, Va.

606 Impacts of a Nominal Nuclear Electromagnetic Pulse on Electric Power Systems. Phase III Final Report

ORNL/Sub/83-43374/2 (April 1991)

V. J. Kruse, D. L. Nickel, J. J. Bonk, E. R. Taylor, Jr. ABB Power Systems, Inc., Advanced

Systems Technology, Pittsburgh, $\mathrm{Pa}$. 
607 Impact of Steep-Front Short-Duration Impulse on Electric Power System Insulation. Phase I: Laboratory Evaluation of Selected Power System Components ORNL/Sub/85-28611/2 (April 1991)

L. M. Burrage, E. F. Veverka, J. H. Shaw. Cooper Power Systems, Franksville, Wis.

B. W. McConnell. Oak Ridge National Laboratory, Oak Ridge, Tenn.

608 System Reconflguration Analysls Program (SYSRAP) User's Manual ORNL-6575 (April 1991)

J. B. Patton. Consultant to Oak Ridge National Laboratory, Oak Ridge, Tenn.

D. T. Rizy. Oak Ridge National Laboratory, Oak Ridge, Tenn.

J. S. Lawler. University of Tennessee, Knoxville, Tenn.

609 On Estimation of Uncertainties in Analog Measurements IEEE Trans. Power Systems 5(4), pp. 1222-28 (November 1990)

M. M. Adibi. Consultant to Oak Ridge National Laboratory, Oak Ridge, Tenn.

J. P. Stovall. Oak Ridge National Laboratory, Oak Ridge, Tenn.

610 Induced Voltage on an Overhead Line Due to Nearby LIghtning IEEE Trans. Electromagnetic Compatibility 32(4), pp. 292-99 (November 1990)

G. Diendorfer. Technical University, Vienna, Austria

611 An Improved Return Stroke Model with Specifled Channel-Base Current Journal of Geophysical Research 95(D9), pp. 13,621-44 (August 20, 1990)

G. Diendorfer. Technical University, Vienna, Austria

M. A. Uman. University of Florida, Gainesville, Fla.

612 Updated Evaluation of Polymer Films for Electrical Insulation ORNL-6603 (August 1990)

H. E. McCoy, Jr. Oak Ridge National Laboratory, Oak Ridge, Tenn.

613 Polarization Currents in Varistors

J. Appl. Phys. 68(1), pp. 339-45 (July 1990)

F. A. Modine. Oak Ridge National Laboratory, Oak Ridge, Tenn.

R. W. Major. University of Richmond, Va.

S.-I. Choi, L. B. Bergman, M. N. Silver. University of North Carolina, Chapel Hill, N.C.

614 Translent Response of a Distribution CIrcult Recloser and Control Unit to a High-Altitude Electromagnetic Pulse (HEMP) and LIghtning

IEEE Trans. Electromagnetic Compatibility 32(2), pp. 113-24 (May 1990)

P. R. Bames. Oak Ridge National Laboratory, Oak Ridge, Tenn.

F. M. Tesche. Consultant to Oak Ridge National Laboratory, Oak Ridge, Tenn.

615 Pulse Response Characteristics of Zno Varistors

J. Appl. Phys. 67(10), pp. 6560-66 (May 1990)

F. A. Modine. Oak Ridge National Laboratory, Oak Ridge, Tenn.

R. B. Wheeler. Los Alamos National Laboratory, Los Alamos, N. Mex.

616 Load Flow Studies in the Presence of Magnetohydrodynamic

Electromagnetic Pulse

IEEE Trans. Power Delivery 5(2), pp. 1158-63 (April 1990)

V. J. Kruse, G. B. Rackcliffe. Westinghouse Electric Corp., Pittsburgh, Pa.

P. R. Barnes. Oak Ridge National Laboratory, Oak Ridge, Tenn. 
617 Appllcations Software for Modeling Distrlbution Automation Operatlons on the Athens Utilltes Board

IEEE Trans. Power Delivery 5(2), pp. 1019-25 (April 1990)

J. B. Patton. Consultant to Oak Ridge National Laboratory, Oak Ridge, Tenn.

D. T. Rizy. Oak Ridge National Laboratory, Oak Ridge, Tenn.

J. S. Lawler. University of Tennessee, Knoxville, Tenn.

618 Flashover Vulnerabillty of Transmission and Distribution Lines to HighAltitude Electromagnetlc Pulse (HEMP)

IEEE Trans. Power Delivery 5(2), pp. 1164-69 (April 1990)

V. J. Kruse. Westinghouse Electric Corp., Pittsburgh, Pa.

P. R. Bames. Oak Ridge National Laboratory, Oak Ridge, Tenn.

F. M. Tesche. Consultant to Oak Ridge National Laboratory, Oak Ridge, Tenn.

619 The Effects of Steep-Front Short-Duration Impulses on Power Distribution Component

IEEE Trans. Power Delivery 5(2), pp. 708-15 (April 1990)

D. B. Miller, A. E. Lux, S. Grzybowski. Mississippi State University, Mississippi State, Miss.

P. R. Bames. Oak Ridge National Laboratory, Oak Ridge, Tenn.

620 On the Radiation Field Turn-on Term Assoclated with Travelling Current Discontinuities in LIghtning

Journal of Geophysical Research 95(D4), pp. 3711-13 (March 1990)

M. Rubinstein, M. A. Uman. University of Florida, Gainesville, Fla.

621 Analysis of Power Sector Efficlency Improvements for an Integrated Utility Planning Process in Costa Rica

Proceedings 25th Intersociety Energy Conversion Engineering Conference 4, pp. 38692 (New York: American Institute of Chemical Engineers, 1990)

D. B. Waddle, J. M. MacDonald. Oak Ridge National Laboratory, Oak Ridge, Tenn.

622 Measurement of Partial Discharges in Hexane Under DC Voltage IEEE Trans. Electr. Insul. 24, pp. 1109-19 (December 1989)

E. F. Kelley, M. Nehmadi, R. E. Hebner. National Institute for Standards and Testing, Gaithersburg, Md.

M. O. Pace, A. L. Wintenberg, T. V. Blalock, J. V. Foust. University of Tennessee, Knoxville, Tenn.

623 Integrated Hierarchical Computer Systems for Adaptive Protective Relaying and Control of Electric Transmission Power Systems ORNL/Sub/85-22005/1 (November 1989)

A. G. Phadke. Virginia Polytechnic Institute and State University, Blacksburg, Va.

S. H. Horowitz. American Electric Power Company, Inc., Columbus, Ohio

J. S. Thorp. Cornell University, Ithaca, N.Y.

624 Adaptive Protective Relaying of Transmission Power Systems for Improved Rellability

ORNL/Sub/85-22012/1 (September 1989)

G. D. Rockefeller, R. T. Byerly, W. E. Feero, C. L. Wagner. Electric Research and Management, Inc., State College, Pa.

K. L. Hicks. Stone \& Webster Engineering Corp., Boston, Mass.

J. R. Linders. Consultant to Oak Ridge National Laboratory, Oak Ridge, Tenn.

J. Nichol. A. D. Little, Inc., Cambridge, Mass. 
625 HEMP Test and Analysis of Selected Recloser-Control Units ORNL/Sub/88-00238/1 (August 1989)

T. K. Liu, S. H. Sands. LuTech, Inc., Oakland, Calif.

F. M. Tesche. E-Systems, Inc., Greeneville, Texas

P. R. Bames. Oak Ridge National Laboratory, Oak Ridge, Tenn.

626 Zlnc Oxide Varlstor Response Time

Proceedings of the Second International Varistor Conference on Zinc Oxide Varistors: Science and Technology, Schenectady, Now York, December 5-7, 1988 3, pp. 176-85

(Westerville, Ohio: American Ceramic Society, 1989)

F. A. Modine. Oak Ridge National Laboratory, Oak Ridge, Tenn.

R. W. Major. University of Richmond, Richmond, Va.

S.-I. Choi, L. B. Bergman, M. N. Silver. University of North Carolina, Chapel Hill, N.C.

627 Automating Electric Utility Distribution Systems: The Athens Automation and Control Experiment

New York: Prentice Hall, 1989

P. A. Gnadt, J. S. Lawler. Consultants to Oak Ridge National Laboratory, Oak Ridge, Tenn.

628 The HEMP Response of an Overhead Power Distribution LIne

IEEE Trans. Power Delivery 4, pp. 1937-44 (1989)

F. M. Tesche. E-Systems, Inc., Greeneville, Texas

P. R. Barnes. Oak Ridge National Laboratory, Oak Ridge, Tenn.

629 Analysis of Water Heater Data from Athens Load Control Experiment IEEE Trans. Power Delivery 4, pp. 1232-38 (1989)

J. H. Reed. Oak Ridge National Laboratory, Oak Ridge, Tenn.

J. C. Thompson, R. P. Broadwater, A. Chandrasekaran. Tennessee Technological

University, Cookeville, Tenn.

630 Pulsed Charge Transport in Polycrystalline Zinc Oxide

Bulletin of the American Physical Society 34, p. 999 (1989)

J. F. Cordaro. Alfred University, Alfred, N.Y.

F. A. Modine. Oak Ridge National Laboratory, Oak Ridge, Tenn.

631 The Induced Current in Parallel WIres Over an Imperfect Ground From an Incident EMP

Proceedings 1989 Southeastcon, IEEE Regional Meeting, University of South Carolina, Columbia, S.C., April 1989, Vol. 2 (New York: IEEE, 1989)

H. P. Neff, Jr. University of Tennessee, Knoxville, Tenn.

D. A. Reed. Consultant to Oak Ridge National Laboratory, Oak Ridge, Tenn.

632 Spark Decomposition of SF6: Chemical and Blological Studies IEEE Trans. Power Delivery 4, pp. 1541-551 (1989)

G. D. Griffin, I. Sauers, C. E. Easterty. Oak Ridge National Laboratory, Oak Ridge, Tenn.

K. Kurka. University of Tennessee, Knoxville, Tenn.

633 Distribution Automation Applications Software for the Athens UtIIItes

Board

IEEE Trans. Power Delivery 4, pp. 715-24 (1989)

D. T. Rizy. Oak Ridge National Laboratory, Oak Ridge, Tenn.

J. S. Lawler. University of Tennessee, Knoxville, Tenn.

J. B. Patton. Consultant to Oak Ridge National Laboratory, Oak Ridge, Tenn.

N. H. Fortson. Athens Utilities Board, Athens, Tenn. 
634 Impact of Automation on the Rellability of the Athens Utillties Board's Distrlbution System

IEEE Trans. Power Delivery 4, pp. 770-78 (1989)

L. D. Monteen. Athens Utilities Board, Athens, Tenn.

J. S. Lawler, J. S. Lai. University of Tennessee, Knoxville, Tenn.

J. B. Patton. Consultant to Oak Ridge National Laboratory, Oak Ridge, Tenn.

D. T. Rizy. Oak Ridge National Laboratory, Oak Ridge, Tenn.

635 A Multiconductor Model for Determining the Response of Power Transmission and Distribution LInes to a High Altitude Electromagnetic Pulse (HEMP)

IEEE Trans. Power Delivery 4, pp. 1955-64 (1989)

F. M. Tesche. E-Systems, Inc., Greeneville, Texas

P. R. Bames. Oak Ridge National Laboratory, Oak Ridge, Tenn.

636 Steep Front-Short Duration Voltage Surge Tests of Power LIne FItters and Translent Voltage Suppressors

IEEE Trans. Power Delivery 4, pp. 1029-36 (1989)

P. R. Barnes, T. L. Hudson. Oak Ridge National Laboratory, Oak Ridge, Tenn.

637 Instrumentation System Used to Determine the Effects of Steep FrontShort Duration Impulses on Electric Power System Insulation IEEE Trans. Power Delivery 4, pp. 938-41 (1989)

J. H. Shaw. McGraw-Edison Power Systems, Franksville, Wis.

638 Experimental Determination of the Effects of Steep Front-Short Duration Surges on 25 KVA Pole Mounted DIstribution Transformers

IEEE Trans. Power Delivery 4, pp. 1103-10 (1989)

C. H. Eichler, J. R. Legro. Westinghouse Electric Corp., Pittsburgh, Pa.

P. R. Bames. Oak Ridge National Laboratory, Oak Ridge, Tenn.

639 Measuring and Analyzing the Impact of Voltage and Capacitor Control with High Speed Data Acquisition

IEEE Trans. Power Delivery 4, pp. 704-14 (1989)

D. T. Rizy, W. R. Nelson. Oak Ridge National Laboratory, Oak Ridge, Tenn.

J. S. Lawler. University of Tennessee, Knoxville, Tenn.

J. B. Patton. Consultant to Oak Ridge National Laboratory, Oak Ridge, Tenn.

640 Monitoring Load Control at the Feeder Level Using High Speed Monitoring Equipment

IEEE Trans. Power Delivery 4, pp. 694-703 (1989)

J. H. Reed, W. R. Nelson, G. R. Wetherington, E. R. Broadaway. Oak Ridge National

Laboratory, Oak Ridge, Tenn.

641 The Origin of the Pulse Response Characteristics of Zinc Oxide Varistors J. Appl. Phys. 66, pp. 5608-12 (1989)

F. A. Modine, R. B. Wheeler. Oak Ridge National Laboratory, Oak Ridge, Tenn.

Y. Shim, J. F. Cordaro. Alfred University, Alfred, N.Y.

642 Load Control Experiments With Heat Pumps During the Winter

IEEE Trans. Power Delivery 4, pp. 646-52 (1989)

J. H. Reed. Oak Ridge National Laboratory, Oak Ridge, Tenn.

R. P. Broadwater, A. Chandrasekaran. Tennessee Technological University, Cookeville, Tenn. 


\section{SUPERCONDUCTING TECHNOLOGY PROGRAM FOR ELECTRIC ENERGY SYSTEMS}

643 Observed Regimes of Collective Flux Creep In Proton-Irradiated, Single Crystal YBaCuO: Dependence on Current Density Phys. Rev. B 49(18), p. 13287 (May 1994)

J. R. Thompson, D. K. Christen. Oak Ridge National Laboratory, Oak Ridge, Tenn.

Y. R. Sun. University of Tennessee, Knoxville, Tenn.

L. Civale, A. D. Manwick, F. Holtzberg. IBM Thomas J. Watson Research Center, Yorktown Heights, N. Y.

644 Single Step Synthesis of Bulk $\mathrm{HgBa}_{2} \mathrm{Ca}_{2} \mathrm{Cu}_{3} \mathrm{O}_{8}+\delta$ Superconductors Physica C222(1-2), p. 7 (March 10, 1994)

M. Paranthaman. Oak Ridge National Laboratory, Oak Ridge, Tenn.

645 Thermoelectric Power and Resistivity of Bulk $\mathrm{HgBa}_{2} \mathrm{CuO}_{4+\mathrm{y}}$ Superconductors and the Effects of Annealing Physica C 222(1-2), p. 47 (March 10, 1994) C. K. Subramaniam. A. B. Kaiser. Victoria University of Wellington, Wellington, New Zealand.

M. Paranthaman. Oak Ridge National Laboratory, Oak Ridge, Tenn.

646 ORNL Superconducting Technology Program for Electric Power Systems-Annual Report for FY 1993

ORNL/HTSCP-5 (March 1994)

R. A. Hawsey. Oak Ridge National Laboratory, Oak Ridge, Tenn.

647 Fabrication and Testing of High Temperature Superconducting Wires and Colls

ORNL/M-3313 (February 1994)

R. A. Hawsey. Oak Ridge National Laboratory, Oak Ridge, Tenn.

648 Development of a Commerclally Viable Manufacturing Process for Making Low, Unlform, Continuous Lengths of High Temperature Superconducting Wire

ORNL/M-3314 (February 1994)

R. A. Hawsey. Oak Ridge National Laboratory, Oak Ridge, Tenn.

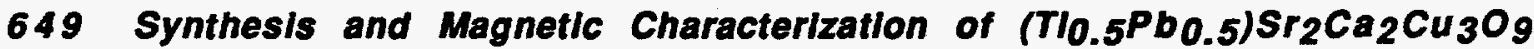
and $\mathrm{Tl}_{2} \mathrm{Ba}_{2} \mathrm{CaCu}_{2} \mathrm{O}_{8}$ Bulk Superconductors

Physica C 219(3-4), p. 413 (January 15, 1994)

M. Paranthaman. Oak Ridge National Laboratory, Oak Ridge, Tenn.

M. Foldeaki, R. Tello, A. M. Hermann. University of Colorado, Boulder, Colo.

650 Local Texture and Percolative Paths for Long-Range Conduction In High Critical Current Density $\mathrm{TIBa}_{2} \mathrm{Cu}_{3} \mathrm{O}_{8+x}$ Deposits

Appl. Phys. Lett. 64(1), pp. 106-108 (January 3, 1994)

D. M. Kroeger, A. Goyal, E. D. Specht, Z. L. Wang. Oak Ridge National Laboratory, Oak Ridge, Tenn.

J. E. Tkaczyk, J. A. Sutliff, J. A. DeLuca. General Electric Corp. R\&D Center,

Schenectady, N. Y. 
651 The Effect of Geometry on the Critical Currents of Thin Films

Phys. Rev. B 49(2), p. 1274 (January 1, 1994)

G. Stejic, A. Gurevich, E. Kadyrov, R. Joynt, D. C. Larbalestier. University of Wisconsin, Madison, Wisc.

D. K. Christen. Oak Ridge National Laboratory, Oak Ridge, Tenn.

652 On the Connection Between the Normal Zone Voltage and the Hot Spot Temperature in Uncooled Magnets

Cryogenics 34(2), pp. 111-18 (1994)

L. Dresner. Oak Ridge National Laboratory, Oak Ridge, Tenn.

653 Thallium-Based High-Tc Superconducting Oxides-A Summary in Organic Conductors: Fundamentals and Applications, ed. J. P. Farges (New York: Marcel Dekker, 1994)

M. Paranthaman. Oak Ridge National Laboratory, Oak Ridge, Tenn.

A. M. Hermann. University of Colorado, Boulder, Colo.

654 Quench Energles of Uncooled Superconductors Cryogenics 34(1), pp. 77-82 (1994)

L. Dresner. Oak Ridge National Laboratory, Oak Ridge, Tenn.

655 Vortex Fluctuation, Magnetic Penetration Depth, and HC2 in Hg- and TBased HIgh-TC Superconductors

Phys. Rev. B. 48(18), pp. 14031-34 (November 1, 1993)

J. R. Thompson, J. G. Ossandon, D. K. Christen, B. C. Chakoumakos, M. Paranthaman, J. Brynestad. Oak Ridge National Laboratory, Oak Ridge, Tenn.

Y. R. Sun. University of Tennessee, Knoxville, Tenn.

656 Graln-Boundary Chemistry and Weak-LInk Behavior of Polycrystalline $\mathrm{YBa}_{2} \mathrm{Cu}_{4} \mathrm{O}_{8}$

Phys. Rev. B 48(13), pp. 9726-34 (October 1, 1993)

Z. L. Wang, J. Brynestad, D. M. Kroeger, J. R. Thompson, R. K. Williams. Oak Ridge

National Laboratory, Oak Ridge, Tenn.

Y.R. Sun. University of Tennessee, Knoxville, Tenn.

657 A Teacher's Guide to Superconductivity for High School Students ORNL/M-3063 (October 1993)

R. W. Dull. Largo High School, Largo, Fla.

H. R. Kerchner. Oak Ridge National Laboratory, Oak Ridge, Tenn.

658 Oxygen Tracer Diffusion in $\mathrm{YBa}_{2} \mathrm{Cu}_{4} \mathrm{O}_{8}$

Phys. Rev. B 48(10), p. 7505 (September 1, 1993)

J. L. Routbort, S. J. Rothman, J. N. Mundy. Argonne National Laboratory, Argonne, III.

J. E. Baker. University of Illinois, Urana, III.

B. Dabrowski. Northem Illinois University, DeKalb, III.

R. K. Williams. Oak Ridge National Laboratory, Oak Ridge, Tenn.

659 Stabllity and Protection of Ag/BSCCO Magnets Operated in the $20-40 \mathrm{~K}$ Range

Cryogenics 33(9), pp. 900-909 (September 1993)

L. Dresner. Oak Ridge National Laboratory, Oak Ridge, Tenn. 
660 Synthesis and Magnetic Characterization of the High-TC Superconducting Compound $\mathrm{HgBa}_{2} \mathrm{CuO}_{4+\delta}$

Physica C 213(3-4), p. 271 (August 15, 1993)

M. Paranthaman, J. R. Thompson, J. R. Brynestad. Oak Ridge National Laboratory, Oak Ridge, Tenn.

Y. R. Sun. University of Tennessee, Knoxville, Tenn.

661 Design Considerations for a 1-kWh Energy Storage Magnet

ORNL/M-2950 (August 1993)

R. A. Hawsey. Oak Ridge National Laboratory, Oak Ridge, Tenn.

662 YBCO Films by Metal-Organic Chemical Vapor Deposition

ORNL/M-2951 (August 1993)

R. A. Hawsey. Oak Ridge National Laboratory, Oak Ridge, Tenn.

663 YBCO and BSCCO Thick Film Superconductors on Practical Substrates ORNL/M-2952 (August 1993)

R. A. Hawsey. Oak Ridge National Laboratory, Oak Ridge, Tenn.

664 Aerosol Powder Synthesis

ORNL/M-2953 (August 1993)

R. A. Hawsey. Oak Ridge National Laboratory, Oak Ridge, Tenn.

665 Multiple Laser Beam and Segmented Target Laser Ablation Application to HTSC FIIm Deposition

ORNL/M-2955 (August 1993)

R. A. Hawsey. Oak Ridge National Laboratory, Oak Ridge, Tenn.

666 Deposited Conductor Fabrication

ORNL/M-2956 (August 1993)

R. A. Hawsey. Oak Ridge National Laboratory, Oak Ridge, Tenn.

667 In-Situ Monitoring of the Preparation of High $T_{C}$ Superconducting Films ORNL/M-2957 (August 1993)

R. A. Hawsey. Oak Ridge National Laboratory, Oak Ridge, Tenn.

668 Microdiffraction Measurements of Correlations in Grain Orlentation In High Current, High Temperature Superconductors ORNL/M-2986 (August 1993)

E. D. Specht, A. Goyal, D. M. Kroeger, Z. L. Wang. Oak Ridge National Laboratory, Oak Ridge, Tenn.

J. E. Tkaczyk, J. A. DeLuca. General Electric Corp. R\&D Center, Schenectady, N. Y.

669 Development of Large Critical Current HIgh $T_{C}$ Superconducting Fllms on Flexible Substrates

ORNL/M-2958 (August 1993)

R. A. Hawsey. Oak Ridge National Laboratory, Oak Ridge, Tenn.

670 Superconductivity: Current Problems at High $T_{c}$

Nature 364(6433), pp. 98-99 (July 8, 1993)

D. K. Christen, J. R. Thompson. Oak Ridge National Laboratory, Oak Ridge, Tenn.

671 Current Problems at HIgh TC

Nature 364, pp. 98-99 (July 1993)

D. K. Christen, J. R. Thompson. Oak Ridge National Laboratory, Oak Ridge, Tenn. 
672 Enhanced Transport Critical Current at High Flelds After Heavy Ion Irradlation of Textured $\mathrm{TlBa}_{2} \mathrm{Ca}_{2} \mathrm{Cu}_{3} \mathrm{O}_{2}$ Thick Films

Appl. Phys. Lett. 62(23), Pp. 3031-33 (June 7, 1993)

J. E. Tkaczyk, J. A. DeLuca, P. L. Karas, P. J. Bednarczyk. General Electric Corp. R\&D Center, Schenectady, N. Y.

D. K. Christen, C. E. Klabunde, H. R. Kerchner. Oak Ridge National Laboratory, Oak Ridge, Tenn.

673 Strong Evidence for Vortex-Glass-Collective-PInning Theory in $\mathrm{YBa}_{2} \mathrm{Cu}_{3} \mathrm{O}_{7}$ Superconductors

Phys. Rev. B 47(21), pp. 14481-88 (June 1, 1993)

J. R. Thompson, D. K. Christen, A. Goyal. Oak Ridge National Laboratory, Oak Ridge, Tenn.

Y. R. Sun, Y. J. Chen. University of Tennessee, Knoxville, Tenn.

674 Effect of Flux Creep on the Temperature Dependence of the Current Density in YBaCuO Crystals

Phys. Rev. B 47(21), pp. 14440-47 (June 1,1993)

J. R. Thompson. Oak Ridge National Laboratory, Oak Ridge, Tenn.

Y. R. Sun. University of Tennessee, Knoxville, Tenn.

L. Civale, A. P. Malozemoff, M. W. McElfresh, A. D. Manwick, F. Holtzberg. IBM Thomas J.

Watson Research Center, Yorktown Heights, N. Y.

675 Understanding Superconducting Magnetic Energy Storage (SMES) Technology, Applications, and Economics

ORNL/Sub/88-SM362/1 (June 1993)

B. W. McConnell. Oak Ridge National Laboratory, Oak Ridge, Tenn.

R. J. Ferraro. Ferraro, Oliver, and Associates, Inc., Knoxville, Tenn.

676 Solidification of $\mathrm{YBa}_{2} \mathrm{Cu}_{3} \mathrm{O}_{7-\delta}$ from the Melt

Physica C 210(1/2), p. 197 (May 15, 1993)

A. Goyal, K. B. Alexander, D. M. Kroeger. Oak Ridge National Laboratory, Oak Ridge, Tenn.

P. D. Funkenbusch, S. J. Bums. University of Rochester, Rochester, N. Y.

677 In-Plane Epitaxial Alignment of $\mathrm{Yba}_{2} \mathrm{Cu}_{3} \mathrm{O}_{7-x}$ Fllms Grown on Sllver Crystals and Buffer Layers

Appl. Phys. Lett. 62(15), pp. 1836-38 (April 12, 1993)

J. D. Budai. Oak Ridge National Laboratory, Oak Ridge, Tenn.

R. T. Young, B. S. Chao. Energy Conversion Devices, Inc., Troy, Mich.

678 Structural and Chemical Disorder Near the $\mathrm{Y}_{2} \mathrm{BaCuO}_{5} / \mathrm{YBa}_{2} \mathrm{Cu}_{3} \mathrm{O}_{7-\delta}$ Interface and its Possible Relation to the Flux-PIning Behavior in MeltTextured $\mathrm{YBa}_{2} \mathrm{Cu}_{3} \mathrm{O}_{7-\delta}$

Phys. Rev. B 47(9), pp. 5373-82 (March 1, 1993)

Z. L. Wang. University of Tennessee, Knoxville, Tenn.

A. Goyal, D. M. Kroeger. Oak Ridge National Laboratory, Oak Ridge, Tenn. 
679 Effective Vortex PInning Energy $U_{e f f(J, T)}$ In High-TC Superconductors with Polnt- and Line-Llke Defects

Bull. Am. Phys. Soc. 38, p. 835 (March 1993)

J. R. Thompson, D. K. Christen, H. R. Kerchner, B. C. Sales, B. C. Chakoumakos. Oak Ridge National Laboratory, Oak Ridge, Tenn.

L. Civale, A. D. Manwick, F. Holtzberg. IBM Thomas J. Watson Research Center, Yorktown Heights, N. Y.

Y. R. Sun, Y. J. Chen. University of Tennessee, Knoxville, Tenn.

680 Effect of Heat Treatment Conditions on Critical Current of $\mathrm{YBa}_{2} \mathrm{Cu}_{3} \mathrm{O}_{7-\delta} / \mathrm{Ag}$ Powder-In-Tube Wires

Superconductor Science and Technology 6(2), pp. 106-11 (February 1993)

J. C. Bowker, G. A. Whitlow. Westinghouse Science and Technology Center, Pittsburgh, $\mathrm{Pa}$.

681 ORNL Superconducting Technology Program for Electric Energy Systems-Annual Report for FY 1992

ORNLHTSPC-4 (February 1993)

R. A. Hawsey. Oak Ridge National Laboratory, Oak Ridge, Tenn.

682 The Team Sport of Technology Transfer: Spectators Welcome Superconductor Industry Magazine, pp. 12-19 and 30 (Summer 1993)

R. A. Hawsey. Oak Ridge National Laboratory, Oak Ridge, Tenn.

J. G. Daley. Office of Energy Efficiency and Renewable Energy, Department of Energy, Washington, D. C.

683 Enhanced Transport Critical Current at HIgh Flelds After Ag-Ion Irradiation of Polycrystalline TI(1223) Films

Bull. Am. Phys. Soc. 38, p. 830 (1993)

J. E. Tkaczyk, J. A. DeLuca, P. L. Karas, P. J. Bednarczyk. General Electric Corp. R\&D

Center, Schenectady, N. Y.

D. K. Christen. Oak Ridge National Laboratory, Oak Ridge, Tenn.

684 Synthesis and Magnetic Characterization of the High-TC

Superconducting Compound $\mathrm{HgBa}_{2} \mathrm{CuO}_{4+\delta}$

Physica C 213, pp. 271-75 (1993)

M. Paranthaman, J. R. Thompson, J. Brynestad. Oak Ridge National Laboratory, Oak

Ridge, Tenn.

Y. R. Sun. University of Tennessee, Knoxville, Tenn.

685 Vortex Dynamics in YBaCuo Single Crystals with Polnt- and Line-Like Defects-Flux Creep Studies

Physica A 200, pp. 395-402 (1993)

J. R. Thompson, D. K. Christen. Oak Ridge National Laboratory, Oak Ridge, Tenn.

Y. R. Sun. University of Tennessee, Knoxville, Tenn.

L. Civale, A. D. Manwick, F. Holtzberg. IBM Thomas J. Watson Research Center, Yorktown Heights, N. Y.

686 Electrical Transport Dissipation and Flux PInning In Superconducting Films with Columnar Defects

Bull. Am. Phys. Soc. 38, p. 802 (1993)

D. K. Christen, C. E. Klabunde, H. R. Kerchner, S. Zhu, R. Feenstra, J. R. Thompson.

Oak Ridge National Laboratory, Oak Ridge, Tenn.

J. E. Tkaczyk. General Electric Corp. R\&D Center, Schenectady, N. Y.

J. M. Phillips. AT\&T Bell Laboratories, Murray Hill, N. J. 
687 Electrical Transport Propertles of Oxygen Deficient $\mathrm{YBa}_{2} \mathrm{Cu}_{3} \mathrm{O}_{7-\delta}$ Thin Films

Bull. Am. Phys. Soc. 38, p. 272 (1993)

E. C. Jones. University of Tennessee, Knoxville, Tenn.

D. K. Christen, J. R. Thompson, R. Feenstra, S. Zhu, D. H. Lowndes. Oak Ridge National Laboratory, Oak Ridge, Tenn.

688 Superconductive Transport Properties of Heavy Ion Irradiated Epltaxial $\mathrm{YBa}_{2} \mathrm{Cu}_{3} \mathrm{O}_{7}$ Thin Films

Bull. Am. Phys. Soc. 38, p. 802 (1993)

S. Zhu, D. K. Christen, C. E. Klabunde, J. R. Thompson, R. Feenstra, D. H. Lowndes, D.

P. Norton. Oak Ridge National Laboratory, Oak Ridge, Tenn.

E. C. Jones. University of Tennessee, Knoxville, Tenn.

689 Epitaxial YBaCuO Fllms on Metal Substrates and Buffer Layers Bull. Am. Phys. Soc. 38, p. 260 (1993)

J. D. Budai, D. P. Norton, B. C. Chakoumakos, R. Feenstra, D. K. Christen, D. H. Lowndes. Oak Ridge National Laboratory, Oak Ridge, Tenn.

R. T. Young. Energy Conversion Devices, Inc., Troy, Mich.

690 DC Magnetization Studies of Anisotropy In Heavy Ion Irradlated $\mathrm{BI}_{2} \mathrm{Sr}_{2} \mathrm{Ca}_{1} \mathrm{Cu}_{2} \mathrm{O}_{8}$ and $\mathrm{Y}_{1} \mathrm{Ba}_{2} \mathrm{Cu}_{3} \mathrm{O}_{7-\delta}$ single Crystals

Bull. Am. Phys. Soc. 38, p. 802 (1993)

J. R. Thompson, D. K. Christen, H. R. Kerchner, C. E. Klabunde, B. C. Sales, B. C.

Chakoumakos. Oak Ridge National Laboratory, Oak Ridge, Tenn.

Y. R. Sun, Y. J. Chen. University of Tennessee, Knoxville, Tenn.

L. Civale, A. D. Marwick, F. Holtzberg. IBM Thomas J. Watson Research Center, Yorktown Heights, N. Y.

691 Properties of Aligned $\mathrm{YBa}_{2} \mathrm{Cu}_{3} \mathrm{O}_{7-\delta} \delta$ Superconductor as a Function of Oxygen Deficlency $\delta$

Appl. Supercond. 1(3-6), pp. 371-80 (1993)

J. G. Ossandon, University of Tennessee, Knoxville, Tenn.

J. R. Thompson, D. K. Christen, B. C. Sales, H. R. Kerchner. Oak Ridge National Laboratory, Oak Ridge, Tenn.

Y. R. Sun. University of Tennessee, Knoxville, Tenn.

J. E. Tkaczyk, K. W. Lay. General Electric Corp. R\&D Laboratory, Schenectady, N. Y.

692 Magnetic Studies of Current Conduction and Flux PInning in High-Tc

Cuprates: Virgin, Irradiated, and Oxygen Deficlent Materlals

Proceedings New York State Conference on Superconductivity and Applications,

Buffalo, New York, September 15-17, 1992, 273, pp. 179-88 (New York: American

Institute of Physics, 1993)

Y. R. Sun, J. G. Ossandon. University of Tennessee, Knoxville, Tenn.

J. R. Thompson, D. K. Christen, H. R. Kerchner, B. C. Sales, B. C. Chakoumakos. Oak

Ridge National Laboratory, Oak Ridge, Tenn.

L. Civale, A. D. Manwick, F. Holtzberg. IBM Thomas J. Watson Research Center, Yorktown

Heights, N. Y. 
693 Magnetization and Flux PInning in High-TC Cuprates: Virgin, Irradiated and Oxygen Deficlent Materials

Proceedings 5th U.S.JJapan Workshop on High $T_{C}$ Superconductors, Tsukuba, Japan,

Nov. 9-10, 1992, pp. 232-36 (Tokyo: Soc. Non-Traditional Technol., 1993)

Y. R. Sun, J. G. Ossandon. University of Tennessee, Knoxville, Tenn.

J. R. Thompson, D. K. Christen, H. R. Kerchner, B. C. Sales, B. C. Chakoumakos. Oak

Ridge National Laboratory, Oak Ridge, Tenn.

L. Civale, A. D. Marwick, F. Holtzberg. IBM Thomas J. Watson Research Center, Yorktown

Heights, N. Y.

694 Flux-PInning-Related Defect Structures In Melt-Processed $\mathrm{YBa}_{2} \mathrm{Cu}_{3} \mathrm{O}_{7-x}$ Proc. 51st Annual Meeting Microsc. Soc. Am., Cincinnati, August 1-6, 1993, pp. 936-37 (San Francisco Press, 1993)

Z. L. Wang, A. Goyal, D. M. Kroeger, L. F. Allard. Oak Ridge National Laboratory, Oak

Ridge, Tenn.

R. Kontra. International Business Machines, Essex Junction, Vermont

695 Nano-Probe Microanalysis of Grain Boundary Chemistry In $\mathrm{YBa}_{2} \mathrm{Cu}_{4} \mathrm{O}_{8}$ and Its Relationship to Weak-Link Behavior

Proc. 51st Annual Meeting Microsc. Soc. Am., Cincinnati, August 1-6, 1993, pp. 598-99 (San Francisco Press, 1993)

Z. L. Wang, J. Brynestad, D. M. Kroeger, J. R. Thompson, R. K. Williams. Oak Ridge

National Laboratory, Oak Ridge, Tenn.

Y.R. Sun. University of Tennessee, Knoxville, Tenn.

696 Irradiation-Enhanced PInning in YBaz $\mathrm{Cu}_{3} \mathrm{O}_{7-x}$ Crystals

JOM, pp. 60-64 (October 1992)

L. Civale, T. K. Worthington, L. Krusin-Elbaum, A. D. Marwick, F. Holtzberg. IBM Thomas

J. Watson Research Center, Yorktown Heights, N. Y.

J. R. Thompson. Oak Ridge National Laboratory, Oak Ridge, Tenn.

M. A. Kirk, R. Wheeler. Argonne National Laboratory, Argonne, III.

697 Protection of a Test Magnet Wound with Ag-BSCCO High-Temperature Superconductor ORNL/HTSPC-3 (October 1992)

L. Dresner. Oak Ridge National Laboratory, Oak Ridge, Tenn.

698 Thermodynamics of the Y-Ba-Cu-C-O-H System: Application to the Organometallic Chemical Vapor Deposition of the $\mathrm{YBa}_{2} \mathrm{Cu}_{3} \mathrm{O}_{7-x}$ Phase J. Am. Ceram. Soc. 75(10), pp. 2679-86 (October 1992)

C. Vahlas. Laboratoire Marcel Mathieu, Centre Helosparc, Paris, France

T. M. Besmann. Oak Ridge National Laboratory, Oak Ridge, Tenn.

699 Superconducting Transport Propertles of Epltaxlal YBa, $\mathrm{Cu}_{3} \mathrm{O}_{7-\delta}$ Thin Films: A Consistent Description Based on Thermally Activated Flux Motion

Phys. Rev. B 46(9), pp. 5576-80 (September 1, 1992)

S. Zhu, E. C. Jones. University of Tennessee, Knoxville, Tenn.

D. K. Christen, C. E. Klabunde, J. R. Thompson, R. Feenstra, D. H. Lowndes, D. P. Norton. Oak Ridge National Laboratory, Oak Ridge, Tenn. 
700 Transport Critical Currents in Spray Pyrolyzed Films of $\mathrm{TlBa}_{2} \mathrm{Ca}_{2} \mathrm{Cu}_{3} \mathrm{O}_{2}$ on Polycrystalline ZIrconla Substrates

Appl. Phys. Lett. 61(5), pp. 610-12 (August 3, 1992)

J. E. Tkaczyk, J. A. DeLuca, P. L. Karas, P. J. Bednarczyk, M. F. Garbauskas, R. H.

Arendt, K. W. Lay. General Electric Corporate Research and Development,

Schenectady, N. Y.

J. S. Moodera. Francis Bitter National Magnet Laboratory, Massachusetts Institute of Technology, Cambridge, Mass.

701 Powder Characteristics and Sintering Behavior of Ag-Doped $\mathrm{YBa}_{2} \mathrm{Cu}_{3} \mathrm{O}_{7-\mathrm{X}}$ Produced by Aerosol Decomposition J. Mater. Res. 7(4), pp. 827-36 (April 1992)

T. L. Ward, T. T. Kodas. University of New Mexico, Albuquerque, N. Mex.

A. H. Carim. Pennsylvania State University, University Park, Pa.

D. M. Kroeger, H. Hsu. Oak Ridge National Laboratory, Oak Ridge, Tenn.

702 Microstructure Within Domains of Melt-Processed $\mathrm{YB}_{2} \mathrm{Cu}_{3} \mathrm{O}_{7-x}$ Superconductors

Phys. Rev. B 45, pp. 5622-27 (March 1992)

K. B. Alexander, A. Goyal, D. M. Kroeger. Oak Ridge National Laboratory, Oak Ridge, Tenn.

V. Selvamanickam, K. Salama. University of Houston, Houston, Texas

703 Proceedings of the HTS WIre Development Workshop, February 1920, 1992. DOE/Office of Utillty Technologies Summary of Projects, Superconducting Technology Program for Electrlc Energy Systems CONF-920286 (Oak Ridge, Tenn.: Oak Ridge National Laboratory, February 1992)

R. A. Hawsey, ed. Oak Ridge National Laboratory, Oak Ridge, Tenn.

704 A Comprehensive Revlew of the XRD Data of the Primary and Secondary Phases Present in the BSCCO Superconductor System (Part II: Ca-Sr-Pb Oxides)

ORNUTM-11949 (February 1992)

B. J. Reardon, C. R. Hubbard. Oak Ridge National Laboratory, Oak Ridge, Tenn.

705 A Comprehensive Review of the XRD Data of the Primary and Secondary Phases Present In the BSCCO Superconductor System (Part I: Ca-Sr-Cu Oxides)

ORNLTM-11948 (January 1992)

B. J. Reardon, C. R. Hubbard. Oak Ridge National Laboratory, Oak Ridge, Tenn.

706 Phase Development in the $\mathrm{Bl}_{2} \mathrm{Sr}_{2} \mathrm{CaCu}_{2} \mathrm{O}_{y}$ System: Effects of Oxygen Pressure

Physica C 202, pp. 134-40 (1992)

F. A. List, H. Hsu, O. B. Cavin, W. D. Porter, C. R. Hubbard, D. M. Kroeger. Oak Ridge

National Laboratory, Oak Ridge, Tenn.

707 Interface Microstructures in Melt-Textured YBan $\mathrm{Cu}_{3} \mathrm{O}_{7-\delta}$ on $\mathrm{Ag}-\mathrm{Pd}$ and Flux Pinning Centers Introduced by $\mathrm{Y}_{2} \mathrm{BaCuO}_{5}$ Particles

Proceedings 50 th Annual Meeting, Electron Microscopy Society of America, Boston,

August 16-21, 1992, pp. 72-73 (Electron Microscopy Society of America, 1992)

Z. L. Wang. University of Tennessee, Knoxville, Tenn.

A. Goyal, D. M. Kroeger. Oak Ridge National Laboratory, Oak Ridge, Tenn. 
$708 T_{C-\delta}$ Relations in $\mathrm{YBa}_{2} \mathrm{Cu}_{3} \mathrm{O}_{7-\delta}$ Thin Fllms: Effects of Oxygen Pressure During Growth

Proceedings, Spring Meeting, Materials Research Society, 275, pp. 101-106

(Pittsburgh: Materials Research Society, 1992)

R. Feenstra, D. P. Norton, J. D. Budai, D. K. Christen, D. H. Lowndes. Oak Ridge National Laboratory, Oak Ridge, Tenn.

V. C. Matijasevic, C.-B. Eom, T. H. Geballe. Stanford University, Stanford, Calif.

E. S. Hellman, E. H. Hartford. AT\&T Bell Labs, Murray Hill, N. J.

709 Thermodynamics of the Y-Ba-Cu-C-O-H System: Application to the Organometallic Chemical Vapor Deposition of the $\mathrm{YBa}_{2} \mathrm{Cu}_{3} \mathrm{O}_{7-x}$ Phase J. Am. Ceram. Soc. 75(10), pp. 2679-86 (1992)

C. Vahlas. Laboratoire Marcel Mathieu, France

T. M. Besmann. Oak Ridge National Laboratory, Oak Ridge, Tenn.

710 Enhanced Current Density $J_{C}$ In Single Crystal $\mathrm{Bl}_{2} \mathrm{Sr}_{2} \mathrm{Ca}_{1} \mathrm{Cu}_{2} \mathrm{O}_{8}$ via Linear Defects from Heavy ion Irradiation

Bull. Am. Phys. Soc. 37, p. 172 (1992)

J. R. Thompson, H. R. Kerchner, D. K. Christen, B. C. Sales, B. C. Chakoumakos. Oak Ridge National Laboratory, Oak Ridge, Tenn.

Y. R. Sun, J. O. Thomson. University of Tennessee, Knoxville, Tenn.

L. Civale, A. D. Marwick. IBM Thomas J. Watson Research Center, Yorktown Heights, N. Y.

711 Flex Creep Studies in Grain-Aligned $\mathrm{YBa}_{2} \mathrm{Cu}_{3} \mathrm{O}_{7-\delta}$ vs Oxygen Deficlency $\boldsymbol{\delta}$

Bull. Am. Phys. Soc. 37, p. 118 (1992)

J. R. Thompson, D. K. Christen. Oak Ridge National Laboratory, Oak Ridge, Tenn.

J. G. Ossandon, Y. R. Sun. University of Tennessee, Knoxville, Tenn.

712 A Review of the XRD Data of the Phases Present in the CaO-Sro-PbO System

Powder Diffr. 7(2), pp. 96-98 (1992)

B. J. Reardon. Affred University, Alfred, N. Y.

C. R. Hubbard. Oak Ridge National Laboratory, Oak Ridge, Tenn.

713 Magnetization Studles of Irradiation Modifled Single Crystal $\mathrm{Y}_{1} \mathrm{Ba}_{2} \mathrm{Cu}_{3} \mathrm{O}_{7}$ Superconductors: Flux Creep and Anneallng Effects

Physics and Materials Science of High Temperature Superconductors, II, pp. 573-93

(Dordrecht: Kluwer, 1992)

J. R. Thompson, D. K. Christen, H. R. Kerchner. Oak Ridge National Laboratory, Oak Ridge, Tenn.

Y. R. Sun. University of Tennessee, Knoxville, Tenn.

A. P. Malozemoff, L. Civale, A. D. Marwick, T. K. Worthington, L. Krusin-Elbaum, F. Holtzberg. IBM Thomas J. Watson Research Center, Yorktown Heights, N. Y.

714 Excess Heat Production In Composite Superconductors During Current Redistribution ORNLTM-11827 (May 1991)

L. Dresner. Oak Ridge National Laboratory, Oak Ridge, Tenn. 


\section{The Structure and Chemistry of Grain Boundarles In Ceramic} Superconductors Proceedings of the American Ceramic Society Second International Ceramic Science and Technology Congress, Orlando, Florida, November 12-15, 1990, 19, pp. 365-72 (Westerville, Ohio: American Ceramic Society, 1991) K. B. Alexander, R. K. Williams, D. M. Kroeger, J. Brynestad. Oak Ridge National Laboratory, Oak Ridge, Tenn.

716 Reduced Flux Motion via Creep Anneallng In High-Jc Single-Crystal $\mathrm{Y}_{1} \mathrm{Ba}_{2} \mathrm{Cu}_{3} \mathrm{O}_{7}$

Appl. Phys. Lett. 59, pp. 2612-14 (1991)

J. R. Thompson, D. K. Christen, H. R. Kerchner. Oak Ridge National Laboratory, Oak Ridge, Tenn.

Y. R. Sun, J. G. Ossandon. University of Tennessee, Knoxville, Tenn.

A. P. Malozemoff, A. Marwick, F. Holtzberg. IBM Thomas J. Watson Research Center, Yorktown Heights, N. Y.

717 Long-Term, Nonlogarithmic Magnetic Relaxation in Single-Crystal $\mathrm{YBa}_{2} \mathrm{Cu}_{3} \mathrm{O}_{7}$ Superconductor

Phys. Rev. B 44, pp. 458-61 (1991)

J. R. Thompson. Oak Ridge National Laboratory, Oak Ridge, Tenn.

Y. R. Sun. University of Tennessee, Knoxville, Tenn.

F. H. Holtzberg. IBM Thomas J. Watson Research Center, Yorktown Heights, N. Y.

718 Critical Current Enhancement by the Extended Vortex Confinement In YBaCuO Single Crystals

Bull. Am. Phys. Soc. 36, p. 669 (1991)

L. Civale, T. K. Worthington, L. Krusin-Elbaum, A. P. Malozemoff, F. Holtzberg, C. A.

Feild. IBM Thomas J. Watson Research Center, Yorktown Heights, N. Y.

J. R. Thompson. Oak Ridge National Laboratory, Oak Ridge, Tenn.

M. A. Kirk. Argonne National Laboratory, Argonne, III.

719 Vortex Conflnement by Columnar Defects In YBa2Cu $3 \mathrm{O}_{7}$ Crystals: Enhanced Pinning at HIgh Fields and Temperatures

Phys. Rev. Lett. 67, pp. 648-51 (1991)

L. Civale, A. D. Marwick, T. K. Worthington, L. Krusin-Elbaum, F. H. Holtzberg. IBM

Thomas J. Watson Research Center, Yorktown Heights, N. Y.

M. A. Kirk. Argonne National Laboratory, Argonne, III.

J. R. Thompson. Oak Ridge National Laboratory, Oak Ridge, Tenn.

Y. R. Sun. University of Tennessee, Knoxville, Tenn.

J. R. Clem. lowa State University, Ames, lowa

720 Critical Currents in Proton Irradlated YBa. $\mathrm{Cu}_{3} \mathrm{O}_{7-\delta}$ Crystals

Progress in High Temperature Superconductivity 31, pp. 25-43 (Singapore: World

Scientific Publishing Co., 1991)

L. Civale, M. W. McElfresh, A. D. Marwick, T. K. Worthington, A. P. Malozemoff, F.

Holtzberg, C. Feild. IBM Thomas J. Watson Research Center, Yorktown Heights, N. Y. J. R. Thompson, D. K. Christen. Oak Ridge National Laboratory, Oak Ridge, Tenn.

M. A. Kirk. Argonne National Laboratory, Argonne, III. 
721 The Hardness and Young's Modulus of Bulk YBa, Cu, $\mathrm{O}_{7-x}$ (1:2:3) and $\mathrm{YBa}_{2} \mathrm{Cu}_{4} \mathrm{O}_{8}$ (1:2:4) as Determined by Uitra Low Load Indentation J. Mater. Res. 6, pp. 2519-22 (1991)

B. N. Lucas. University of Tennessee, Knoxville, Tenn.

W. C. Oliver, R. K. Williams, J. Brynestad. Oak Ridge National Laboratory, Oak Ridge, Tenn.

M. E. O'Hern. Nano Instruments, Inc., Knoxville, Tenn.

722 Anisotropic Thermal Expansion of the 1:2:4 Yttrium Barium Copper Oxide Superconductors

Physica C 172, pp. 486-90 (1991)

K. Doverspike, C. R. Hubbard, R. K. Williams, K. B. Alexander, J. Brynestad, D. M.

Kroeger. Oak Ridge National Laboratory, Oak Ridge, Tenn.

723 Some Observations of the Effects of High Pressures and Temperatures on the Stabllity of $\mathrm{YB}_{2} \mathrm{Cu}_{3} \mathrm{O}_{7-x}$

Journal of Applied Physics 67(11), pp. 6934-39 (1990)

R. K. Williams, K. B. Alexander, J. Brynestad, T. J. Henson, D. M. Kroeger, T. B.

Lindemer, G. C. Marsh, J. O. Scarbrough. Oak Ridge National Laboratory, Oak Ridge,

Tenn.

724 Superconductivity, Inter- and Intra-grain Critical Current Densities of $\mathrm{TI}_{2} \mathrm{Ca}_{2} \mathrm{Ba}_{2} \mathrm{Cu}_{3} \mathrm{O}_{10+x}$ and $\mathrm{Tl}_{2} \mathrm{CaBa}_{2} \mathrm{Cu}_{2} \mathrm{O}_{8}+x$ Materlals

Phys. Rev. B 39, pp. 6652-59 (April 1989)

J. R. Thompson, J. Brynestad, D. M. Kroeger, S. T. Sekula, D. K. Christen, E. D. Specht.

Oak Ridge National Laboratory, Oak Ridge, Tenn.

Y. C. Kin. University of Tennessee, Knoxville, Tenn.

725 Grain Boundarles and Critical Current Density in High Temperature Oxide Superconductors

Journal of Metals 41, pp. 14-17 (1989)

D. M. Kroeger. Oak Ridge National Laboratory, Oak Ridge, Tenn. 



\section{THERMAL ENERGY STORAGE}

726 Thermal Energy Storage Technical Progress Report Aprll 1992-March 1993

ORNL/TM-12384 (May 1993)

M. Olszewski. Oak Ridge National Laboratory, Oak Ridge, Tenn.

727 Thermal Energy Storage Technical Progress Report Aprll 1990-March 1991

ORNLTM-12081 (March 1992)

J. J. Tomlinson. Oak Ridge National Laboratory, Oak Ridge, Tenn.

728 Development of a Complex Compound ChIII Storage System

ORNL/Sub/85-57432/1 (August 1991)

U. Rockenfeller, L. Kirol. Rocky Research, Boulder City, Nev.

729 Turbo Refrigerating Company lce Storage Test Report

ORNLTM-11657 (June 1991)

T.K. Stovall. Oak Ridge National Laboratory, Oak Ridge, Tenn.

730 Wallboard with Latent Heat Storage for Passive Solar Applications ORNLTM-11541 (May 1991)

R. J. Kedl. Oak Ridge National Laboratory, Oak Ridge, Tenn.

731 Thermal Energy Storage Technical Progress Report April 1989-March 1990

ORNLTM-11819 (March 1991)

J. J. Tomlinson. Oak Ridge National Laboratory, Oak Ridge, Temn.

732 Development of Composite Latent/Senslble Heat Storage Media ORNL/Sub/86-95011/1 (December 1990)

R. Petri, E. T. Ong, A. Kardas. Institute of Gas Technology, Chicago, III.

733 Thermal Energy Storage

Mechanical Engineering 112(9) (September 1990)

J. J. Tomlinson. Oak Ridge National Laboratory, Oak Ridge, Tenn.

L. D. Kannberg. Battelle Pacific Northwest Laboratories, Richland, Wash.

734 Bolling/Evaporative Heat Transfer from Spheres in Packed-Bed Thermal Energy Storage Units. Final Report ORNL/Sub/86-7685/2 (May 1990)

R. V. Arimilli, C. A. Moy. University of Tennessee, Knoxville, Tenn.

735 Thermal Energy Storage Technical Progress Report April 1987-March 1988

ORNLTM-11233 (September 1989)

J. J. Tomlinson, R. J. Kedl. Oak Ridge National Laboratory, Oak Ridge, Tenn.

736 Development of Ice Self-Release Mechanisms. Final Report ORNL/SUb/87-SB064/1 (September 1989)

W. E. Stewart, Jr. University of Missouri-Columbia/Kansas City, Truman Campus, Independence, Mo. 
737 Complex-Compound Low-Temperature TES System

U.S. Department of Energy Thermal Energy Storage Research Activities Review 1989 Proceedings, CONF-890351, pp. 217-36 (1989)

U. Rockenfeller. Rocky Research Corp., Boulder City, Nev.

738 Prellminary TES Design Optimization Study for a Simple Periodic Brick PJant

U.S. Department of Energy Thermal Energy Storage Research Activities Review 1989 Proceedings, CONF-890351, pp. 197-207 (1989)

J. B. Drake, M. Olszewski, M. J. Taylor, J. J. Tomlinson. Oak Ridge National Laboratory, Oak Ridge, Tenn.

A. D. Solomon. Consultant to Oak Ridge National Laboratory, Oak Ridge, Tenn.

739 Thermal Energy Storage with Liquid-LIquid Systems

U.S. Department of Energy Thermal Energy Storage Research Activities Review 1989 Proceedings, CONF-890351, pp. 146-70 (1989)

E. A. Santana, L. I. Stiel. New York Polytechnic Institute, Brooklyn, N.Y.

740 Self-Releasing Submerged ice Maker

U.S. Department of Energy Thermal Energy Storage Research Activities Review 1989 Proceedings, CONF-890351, pp. 128-45 (1989)

W. E. Stewart, Jr., M. E. Greer, L. A. Stickler. University of Missouri-Columbia/Kansas City, Truman Campus, Independence, Mo.

741 Computer and Graphics Modellng of Heat Transfer and Phase Change in a Wall with Randomly Imblbed PCM

U.S. Department of Energy Thermal Energy Storage Research Activities Review 1989 Proceedings, CONF-890351, pp. 124-27 (1989)

A. D. Solomon. Consultant to Oak Ridge National Laboratory, Oak Ridge, Tenn.

742 Development of PCM Wallboard for Heating and Cooling of Residential Bullaings

U.S. Department of Energy Thermal Energy Storage Research Activities Review 1989

Proceedings, CONF-890351, pp. 97-123 (1989)

I. Salyer, A. Sircar. University of Dayton Research Institute, Dayton, Ohio

743 Development of a Direct Contact Ice Storage System

U.S. Department of Energy Thermal Energy Storage Research Activities Review 1989

Proceedings, CONF-890351, pp. 93-96 (1989)

C. Poirier. CBI Industries, Plainfield, III.

744 Effects of Dopants on Crystal Structure and Thermal Propertles of Pentaglycerine

U.S. Department of Energy Thermal Energy Storage Research Activities Review 1989

Proceedings, CONF-890351, pp. 58-75 (1989)

D. Chandra, W. Ding. University of Nevada, Reno, Nev.

745 Evaporative Heat Transfer in Beds of Sensible Heat Pellets

U.S. Department of Energy Thermal Energy Storage Research Activities Review 1989

Proceedings, CONF-890351, pp. 26-57 (1989)

R. V. Arimilli, C. A. Moy. University of Tennessee, Knoxville, Tenn.

746 Overview of the Dlurnal and Industrial Thermal Energy Storage Programs

U.S. Department of Energy Thermal Energy Storage Research Activities Review 1989

Proceedings, CONF-890351, pp. 19-25 (1989)

J. J. Tomlinson. Oak Ridge National Laboratory, Oak Ridge, Tenn. 


\section{Activitles in Support of the Wax-Impregnated Wallboard Concept} U.S. Department of Energy Thermal Energy Storage Research Activities Review 1989 Proceedings, CONF-890351, pp. 75-91 (1989)

R. J. Kedl, T. K. Stovall. Oak Ridge National Laboratory, Oak Ridge, Tenn. 



\section{BIOFUELS FEEDSTOCK DEVELOPMENT}

748 Nitrogen Fertilization Strategies in a Short-Rotation Sycamore Plantation Forest Ecology and Management 64(1), pp. 14-24 (March 1994)

H. Van Miegroet, R. J. Norby, T. J. Tschaplinski. Oak Ridge National Laboratory, Oak Ridge, Tenn.

749 Water Stress Tolerance of Black and Eastern Cottonwood Clones and Four Hybrid Progeny. I. Growth, Water Relations and Gas Exchange Canadian Journal of Forest Research 24(2), p. 364 (February 1994) T. J. Tschaplinski, G. A. Tuskan, C. A. Gunderson. Oak Ridge National Laboratory, Oak Ridge, Tenn.

750 Anatomical Considerations Related to Photosynthesis In Cotton (Gossyplum hirsutum L.) Leaves, Bracts, and the Capsule Wall Journal of Experimental Botany 45(270), p. 111 (January 1994)

B. R. Bondada, D. M. Oosterhuis, K. S. Kim, W. M. Harris. University of Arkansas, Fayetteville, Ark.

S. D. Wullschleger. Oak Ridge National Laboratory, Oak Ridge, Tenn.

751 Energy in Synthetic Fertllizers and Pesticides: Revisited ORNL/Sub/90-99732/2 (January 1994)

M. G. Bhat, B. C. English. University of Tennessee, Knoxville, Tenn.

A. F. Turhollow, H. O. Nyangito. Consultants to Oak Ridge National Laboratory, Oak Ridge, Tenn.

752 Blomass Production by Fescue and Swltchgrass Alone and in Mixed Swards with Legumes

ORNL/M-3312 (January 1994)

M. Collins. Oak Ridge National Laboratory, Oak Ridge, Tenn.

753 Short Rotation Woody Crop Trials for Energy Production in North Central U.S. 1992 Annual Report

ORNLM-3220 (January 1994)

E. Hansen, D. Netzer, E. Tolsted, M. Ostry. North Central Forest Experiment Station, Grand Rapids, Minn.

754 ORNL's Blofuels Feedstock Information Resources

Biologue 11, pp. 35-38 (1993)

A. R. Ehrenshaft, L. L. Wright. Oak Ridge National Laboratory, Oak Ridge, Tenn.

755 Considerations In Implementing Integrated Blomass Energy Systems in Developing Countries

Proceedings of the First Biomass Conference of the Americas-Energy, Environment, Agriculture, and Industry, August 30-September 2, 1993, Burlington, Vermont (Golden, Colo.: National Renewable Energy Laboratory, 1993)

R. D. Perlack, J. W. Ranney. Oak Ridge National Laboratory, Oak Ridge, Tenn.

756 Blomass Resource Potentlal Using Energy Crops

Proceedings of the First Biomass Conference of the Americas-Energy, Environment, Agriculture, and Industry, August 30-September 2, 1993, Burlington, Vermont (Golden, Colo.: National Renewable Energy Laboratory, 1993)

L. L. Wright, J. H. Cushman. Oak Ridge National Laboratory, Oak Ridge, Tenn.

S. A. Martin. Midwest Technical Inc., Knoxville, Tenn. 
757 Evaluating a Blomass Resource: The TVA Reglon-Wide Blomass Resource Assessment Model

Proceedings of the First Biomass Conference of the Americas-Energy, Environment, Agriculture, and Industry, August 30-September 2, 1993, Burlington, Vermont (Golden, Colo.: National Renewable Energy Laboratory, 1993)

M. Downing, R. L. Graham. Oak Ridge National Laboratory, Oak Ridge, Tenn.

758 The Role of Natural Resource and Environmental Economics in Determining the Trade-Offs in Consumption and Production of Energy Inputs: The Case of Blomass Energy Crops

Proceedings of the First Biomass Conference of the Americas-Energy, Environment, Agriculture, and Industry, August 30-September 2, 1993, Burlington, Vermont (Golden, Colo.: National Renewable Energy Laboratory, 1993)

M. Downing, R. L. Graham. Oak Ridge National Laboratory, Oak Ridge, Tenn. ;

759 Renewable Blomass Energy: Understanding Regional Scale Environmental Impacts

Proceedings of the First Biomass Conference of the Americas-Energy, Environment, Agriculture, and Industry, August 30-September 2, 1993, Burlington, Vermont (Golden, Colo.: National Renewable Energy Laboratory, 1993)

M. Downing, R. L. Graham. Oak Ridge National Laboratory, Oak Ridge, Tenn. ;

760 Environmental Issues Related to Blomass: An Overview

Proceedings of the First Biomass Conference of the Americas-Energy, Environment, Agriculture, and Industry, August 30-September 2, 1993, Burlington, Vermont (Golden, Colo.: National Renewable Energy Laboratory, 1993)

M. Hughes. U.S. Department of Agriculture, Washington, D. C.

J. W. Ranney. Oak Ridge National Laboratory, Oak Ridge, Tenn.

761 Growing Populus Blomass: Comparison of Woodgrass versus WiderSpaced Short-Rotation Systems

Biomass Bioenergy 4(5), pp. 305-13 (1993)

D. S. DeBell, G. W. Clendenen, J. C. Zasada. USDA Forest Service, Pacific Northwest Station, Portland, Ore.

762 Blofuels Feedstock Development Program Annual Progress Report for 1992

ORNL-6781 (November 1993)

L. L. Wright, J. H. Cushman, A. R. Ehrenshaft, S. B. McLaughlin, S. A. Martin, W. A.

McNabb, J. W. Ranney, G. A. Tuskan, A. F. Turhollow. Oak Ridge National Laboratory, Oak Ridge, Tenn.

763 U.S. Carbon Offset Potentlal Using Blomass Energy Systems

Water, Air, \& Soil Pollution 70(1/4), p. 483 (October 1993)

L. L. Wright. Oak Ridge National Laboratory, Oak Ridge, Tenn.

E. E. Hughes. Electric Power Research Institute, Palo Alto, Calif.

764 Physlological Indicators of Nitrogen Response In a Short Rotation Sycamore Plantation. II. Nitrogen Metabollsm

Canadian Journal of Botany 71, pp. 841-47 (June 1993)

T. J. Tschaplinski, R. J. Norby. Oak Ridge National Laboratory, Oak Ridge, Tenn. 
765 Varlability for Biomass Production and Plant Composition In Serlcea Lespedeza Germplasm, Final Report on a Fleld and Laboratory Research Program for the Period September 30, 1990, to December 31, 1991 ORNL/Sub/90-SG301/1 (May 1993)

J. A. Mosjidis. Aubum University, Auburn, Ala.

766 Realized and Potential Value of Genetics and Blotechnology for Blofuel Feedstock Improvement

pp. 107-109 in Proceedings of the Annual Automotive Technology Development Contractors' Coordination Meeting 1992 P-265 (Warrendale, Pa.: Society of Automotive Engineers, Inc., May 1993)

G. A. Tuskan. Oak Ridge National Laboratory, Oak Ridge, Tenn.

767 New Switchgrass Blofuels Research Program for the Southeast pp. 111-15 in Proceedings of the Annual Automotive Technology Development Contractors' Coordination Meeting 1992 P-265 (Warrendale, Pa.: Society of Automotive Engineers, Inc., May 1993)

S. B. McLaughlin. Oak Ridge National Laboratory, Oak Ridge, Tenn.

768 Clonal and Leaf Age Variation in Populus Phenolic Glycosides: Implications for Host Selection by Chrysomela scripta (Coleoptera: Chrysomelidae)

Environmental Entomology 22(2), pp. 397-403 (April 1993)

B. R. Bingaman, E. R. Hart. lowa State University, Ames, lowa

769 Genetic Improvement and Evaluation of Black Cottonwood for Short Rotation Biomass ProductIon, Progress Report for the Perlod 1987 to 1992

ORNL/Sub/83-43382/8 (April 1993)

R. F. Stettler, T. M. Hinckley, P. E. Heilman, H. D. Bradshaw, Jr. University of Washington, Seattle, Wash.

770 Perennial Species for Optimum Production of Herbaceous Blomass in the Pledmont (Management Study, 1987-1991)

ORNUSub/85-27413/7 (April 1993)

D. J. Parrish, D. D. Wolf, W. L. Daniels. Virginia Polytechnic Institute and State University, Blacksburg, Va.

771 Blochemical and Molecular Bases of Water Stress Tolerance In Populus Annual Progress Report

ORNLM-3222 (April 1993)

T. J. Tschaplinski, G. A. Tuskan. Oak Ridge National Laboratory, Oak Ridge, Tenn.

772 Genetic Blomass and Growth Analysis of Clonal Sllver Maple

(Acersaccherinum L.) in Several Locations

ORNLSub/86-95908/5 (March 1993)

J. E. Preece, W. C. Ashby, C. A. Huetteman, P. L. Roth. Southem Illinois University, Carbondale, III.

773 Selection and Breeding of Pest-Resistant Clones of Populus for Blomass Energy Production in the North Central Region, 1993 Update, Program Growth and Yleld (1988-95 Growing Seasons)

ORNL/Sub/88-43391/7 (March 1993)

R. B. Hall, R. C. Schultz, E. R. Hart, H. S. McNabb. lowa State University, Ames, lowa 
774 Selection and Breeding of Pest-Resistant Clones of Populus for Blomass Energy Production in the North Central Reglon, Annual Report for the Perlod 1 January 1992-31 December 1992

ORNL/Sub/88-43391/6 (February 1993)

R. B. Hall, R. D. Hanna, B. G. McMahon, E. R. Hart, H. S. McNabb. lowa State University, Ames, lowa

775 Screening Alnus for Resistance to Fenusa dohrnll pp. 116-25 in Proceedings Alder Workshop: August 8-9, 1988, Vancouver, B. C. (Ames, lowa: lowa State University Printing Senvice, 1993) R. B. Hall, E. R. Hart, C. S. Duncan. lowa State University, Ames, lowa

776 Responses of Loblolly Pine Seedlings to Elevated $\mathrm{CO}_{2}$ and Fluctuating Water Supply

Tree Physiol. 13, pp. 283-96 (1993)

T. J. Tschaplinski, R. J. Norby, S. D. Wullschleger. Oak Ridge National Laboratory, Oak Ridge, Tenn.

777 Intraspecific Varlation in Photosynthetic Traits of Populus trichocarpa Canadian Journal of Botany 71, pp. 1304-11 (1993)

J. M. Dunlap, J. H. Braatne, T. M. Hinckley, R. F. Stettler. University of Washington, Seattle, Wash.

778 Further Considerations on the Debate Over Herblvore Optimization Theory

Ecol. Appl. 3(1), pp. 30-31 (1993)

D. L. DeAngelis, M. A. Huston. Oak Ridge National Laboratory, Oak Ridge, Tenn.

779 Atmospheric Deposition, Forest Nutrient Status, and Forest Decllne: Impllcations of the Integrated Forest Study pp. 66-81 in Proceedings of Conference on Forest Decline in the Atlantic and Pacific Region, Hilo, Hawaii, June 2-6, 1991 (New York: Springer-Verlag, 1993)

D. W. Johnson. Desert Research Institute, Reno, Nev.

S. E. Lindberg, H. Van Miegroet. Oak Ridge National Laboratory, Oak Ridge, Tenn.

G. M. Lovett. Cary Arboretum, Milbrook, N. Y.

D. W. Cole. University of Washington, Seattle, Wash.

M. J. Mitchell. State University of New York, Syracuse, N. Y.

D. Binkley. Colorado State University, Fort Collins, Colo.

780 Possible Reduction of Atmospheric $\mathrm{CO}_{2}$ by Iron Fertilization in the Antarctic Ocean

pp. 263-85 in GeophysicalGeochemical Aspects of Global Warming (Boca Raton, Fla.: CRC Press, 1993)

T.-H. Peng. Oak Ridge National Laboratory, Oak Ridge, Tenn.

781 Thidiazuron: A Potent Cytokinin for Woody Plant Tissue Culture Plant Cell Tissue and Organ Culture 33, pp. 105-19 (1993)

C. A. Huetteman, J. E. Preece. Southern Illinois University, Champagne, III.

782 Carbon Allocation Terminology: Should It Be More Rational? Bulletin of the Ecological Society of America 74, pp. 175-77 (1993)

R. E. Dickson, J. G. Isebrands. USDA Forest Service, North Central Experiment Station, Rhinelander, Wis. 
783 Production Physiology and Morphology of Populus Species and Thelr Hybrids Grown Under Short Rotation. I. Clonal Comparisons of 4-year Growth and Phenology

Canadian Journal of Forest Research 22(12), p. 1937 (December 1992)

R. J. Ceulemans, G. Scarascia-Mugnozza, B. M. Wiard, J. H. Braatne, T. M. Hinckley, R. F. Stettler, P. E. Heilman. University of Washington, Seattle, Wash.

J. G. Isebrands. USDA Forest Service, North Central Experiment Station, Rhinelander, Wis.

784 Blofuels Feedstock Development Program Annual Progress Report for 1991

ORNL-6742 (July 1992)

L. L. Wright, J. H. Cushman, A. R. Ehrenshaft, S. B. McLaughlin, W. A. McNabb, J. W.

Ranney, G. A. Tuskan, A. F. Turhollow. Oak Ridge National Laboratory, Oak Ridge, Tenn.

785 Environmental Emissions and Socloeconomic considerations in the Production, Storage, and Transportation of Blomass Energy Feedstocks ORNL/TM-12030 (July 1992)

R. D. Perlack, J. W. Ranney, L. L. Wright. Oak Ridge National Laboratory, Oak Ridge, Tenn.

786 Development of Blomass Energy Crops

Proceedings of the Annual Automotive Technology Development Contractors' Coordination Meeting 1991 P-256, pp. 687-89 (Warrendale, Pa.: Society of Automotive Engineers, June 1992)

L. L Wright, J. H. Cushman. Oak Ridge National Laboratory, Oak Ridge, Tenn.

787 Genetic Improvement of Hybrid Poplars for Short Rotation Blomass

\section{Production}

Proceedings of the Annual Automotive Technology Development Contractors'

Coordination Meeting 1991 P-256, pp. 691-92 (Warrendale, Pa.: Society of

Automotive Engineers, June 1992)

R. F. Stettler, T. M. Hinckley, H. D. Bradshaw, Jr. University of Washington, Seattle, Wash.

P. E. Heilman. Washington State University, Seattle, Wash.

788 Selection and Breeding of Pest-Resistant Clones of Populus for Blomass Energy Production in the North Central Reglon

Proceedings of the Annual Automotive Technology Development Contractors'

Coordination Meeting 1991 P-256, pp. 693-702 (Warrendale, Pa.: Society of

Automotive Engineers, June 1992)

R. B. Hall, E. R. Hart, H. S. McNabb, Jr., B. G. McMahon, R. D. Hanna. Lowa State University, Ames, lowa

789 Blofuels Feedstock Production Research Directions for 1992 Proceedings of the Annual Automotive Technology Development Contractors' Coordination Meeting 1991 P-256, pp. 703-707 (Warrendale, Pa.: Society of Automotive Engineers, June 1992)

J. H. Cushman. Oak Ridge National Laboratory, Oak Ridge, Tenn.

790 Selection of Herbaceous Energy Crops for Production in Double Cropping Systems

Proceedings of the Annual Automotive Technology Development Contractors' Coordination Meeting 1991 P-256, pp. 709-12 (Warrendale, Pa.: Society of Automotive Engineers, June 1992)

D. R. Buxton, I. C. Anderson. lowa State University, Ames, lowa 
791 Short Rotation Woody Crop Trlals for Energy Production In North Central U.S.

Proceedings of the Annual Automotive Technology Development Contractors' Coordination Meeting 1991 P-256, pp. 715-16 (Warrendale, Pa.: Society of Automotive Engineers, June 1992)

E. A. Hansen. USDA Forest Service, North Central Experiment Station, Rhinelander, Wis.

792 The Structure and Dynamics of Woody Plant Root Systems pp. 95-123 in Ecophysiology of Short Rotation Forest Crops, ed. C. P. Mitchell et al. (New York: Elsevier Applied Science, 1992)

D. I. Dickmann, K. S. Pregitzer. Michigan State University, East Lansing, Mich.

793 Ecophyslological Growth Process Models of Short-Rotation Forest Crops pp. 231-66 in Ecophysiology of Short Rotation Forest Crops, ed. C. P. Mitchell et al. (New York: Elsevier Applied Science, 1992)

J. G. Isebrands, T. E. Burk. USDA Forest Service, North Central Experiment Station, Rhinelander, Wis.

794 Varlation Among Switchgrasses from Remanent Prairles for Agronomic and Blofuel Traits

Agronomy Abstracts, p. 202 (1992)

A. A. Hopkins. Oklahoma State University, Stillwater, Okla.

K. P. Vogel. University of Nebraska, Lincoln, Neb.

K. J. Moore, K. J. Johnson, I. T. Carlson. lowa State University, Ames, lowa

795 Environmental Considerations In Blomass Resource Management for a Greenhouse-Constrained Soclety

Technologies for a Greenhouse-Constrained Society, ed. M. A. Kuliasha, A. Zucker, and

K. J. Ballew, pp. 519-45 (Chelsea, Mich.: Lewis Publishers, Inc., 1992)

J. W. Ranney. Oak Ridge National Laboratory, Oak Ridge, Tenn.

796 Photosynthesis, Water Relations, and Growth of Two Hybrid Populus Genotypes During a Severe Drought

Can. J. For. Res. 22(8), pp. 1094-1106 (1992)

D. I. Dickmann, Z. Liu, P. V. Nguyen, K. S. Pregitzer. Michigan State University, East Lansing, Mich.

797 Nursery Establlshment, Phenology and Growth of Sllver Maple Related to Provenance

Biomass and Bioenergy 3, pp. 1-7 (1992)

W. C. Ashby, D. F. Bresnan, P. L. Roth, J. E. Preece, C. A. Huetteman. Southem llinois

University, Champagne, III.

798 Genetic Varlation and Productivity of Populus trichocarpa T. \& G. and Its Hybrids: V. The Influence of Ramet Position on Three-Year Growth Variables

Can. J. For. Res. 23, pp. 349-57 (1992)

J. D. Dunlap, R. F. Stettler. University of Washington, Seattle, Wash.

P. E. Heilman. Washington State University, Puyallup, Wash.

799 Environmental and Genetic Influences on Short-Rotation Biomass Production of Black Locust (Robinia pseudoacacla L.) In the Georgla Pledmont

For. Ecol. Manag. 55, pp. 315-31 (1992)

B. C. Bongarten, D. A. Huber, D. K. Apsley. University of Georgia, Athens, Ga. 
800 Genetic and Physlological Investigations of Seedling Development and Steckling Growth for American Sycamore (Platanus occidentalls L.) Doctoral dissertation, Mississippi State University, 1992

Z. Tang. Mississippi State University, Mississippi State, Miss.

801 Blomass Energy Development In Yunnan Province, China. Prellminary Evaluation

ORNL/TM-11791 (June 1991)

R. D. Perlack, J. W. Ranney, M. Russell. Oak Ridge National Laboratory, Oak Ridge,

Tenn.

802 Development of a Farm-Firm Modelling System for Evaluation of Herbaceous Energy Crops

ORNL/Sub/88-SC616/2 (March 1991)

B. C. English, R. R. Alexander, K. H. Loewen, S. A. Coady, G. V. Cole, W. R. Goodman.

Department of Agricultural Economics and Rural Sociology, University of Tennessee,

Knoxville, Tenn.

803 Chilling and Bud Break in Silver Maple

J. Environ. Hort. 9, pp. 1-4 (1991)

W. C. Ashby, D. F. Bresnan, C. A. Huetteman, J. E. Preece, P. L. Roth. Southem Illinois University, Champagne, III.

804 Registration of 'Rebel' Rapeseed

Crop Sci. 31, pp. 485-86 (1991)

D. L. Auld, K. A. Mahler, D. C. Thrill, D. A. Erickson, P. L. Raymer, D. C. Bridges, J. L.

Butler. University of Idaho, Moscow, Idaho

805 Reglstration of Two Rapeseed Germplasm Populations

Crop Sci. 31, pp. 493-94 (1991)

D. L. Auld, K. A. Mahler, D. C. Thrill, D. A. Erickson, P. L. Raymer, J. L. Sernyk. University

of Idaho, Moscow, Idaho

806 Biomass Energy: Exploring the Risks of Commerclallzation in the United States of America

Bioresource Technology 35, pp. 1-13 (1991)

R. A. Cantor, C. G. Rizy. Oak Ridge National Laboratory, Oak Ridge, Tenn.

807 Land Application of Sludge to Forest and Herbaceous Energy Crops Ames Forester, pp. 24-30 (1991)

J. P. Colletti, C. Mize, D. Schultz, L. Rule, A. Skadberg, R. Hall, P. Wray. lowa State

University, Ames, lowa

808 Agroforestry Systems for the Midwest

Ames Forester, pp. 10-13 (1991)

J. P. Colletti, L. Rule, A. Skadberg, D. Schultz, C. Mize, R. Hall, P. Wray. lowa State

University, Ames, lowa

809 Selecting Herbaceous Energy Crops for the Southeast and Midwest/Lake States

Energy from Biomass and Wastes XIV, ed. D. L. Klass, pp. 465-480 (Chicago, Ill.: Institute of Gas Technology, 1991)

J. H. Cushman, A. F. Turhollow. Oak Ridge National Laboratory, Oak Ridge, Tenn. 
810 Leaves as Regulators of Stress Response

Response of Plants to Multiple Stresses, ed. H. A. Mooney et al., pp. 3-34 (San Diego, Calif.: Academic Press, Inc., 1991)

R. E. Dickson, J. G. Isebrands. USDA Forest Service, North Central Experiment Station, Rhinelander, Wis.

811 The Short Rotation Woody Crops Program Data Base

Bioresource Technology 36, pp. 241-246 (1991)

A. R. Ehrenshaft, L. L. Wright. Oak Ridge National Laboratory, Oak Ridge, Tenn.

812 Blomass Crop Production on Representative Southeastern U.S. Farms: Farm Profitability, Erosion Control and the 1985 Food Security ActBioresource Technology 36, pp. 207-214 (1991)

W. R. Goodman, S. A. Coady, B. C. English. University of Tennessee, Knoxville, Tenn.

813 Dormancy Induction Treatment Influence on Western Hemlock Seedlings. I. Seedling Development and Stock Quallty Assessment

Can. J. For. Sci. 21, pp. 164-174 (1991)

S. C. Grossnickle, J. T. Amott, J. E. Major, T. J. Tschaplinski. Oak Ridge National Laboratory, Oak Ridge, Tenn.

814 Activity of the Fenusa dohrnll (Hymenoptera: tenthredenidae) on Alnus in the Northcentral United States

Environ. Entomol. 20, pp. 534-539 (1991)

E. R. Hant, D. G. Petty, R. B. Hall, D. A. Herms, R. D. Hanna, J. N. Kean. lowa State

University, Ames, lowa

815 Dispersal of Fenusa dohrnil (Hymenoptera: tenthredinidae) from an Alnus Short-Rotation Forest Plantation Great Lakes Entomologist 24, pp. 63-68 (1991)

E. R. Hart, R. B. Hall, R. D. Hanna, lowa State University, Ames, lowa

816 Effects of Nitrate on In vitro Nitrate Reductase Activity of Seedilngs from Three Open-Pollinated Familles of Robinla pseudoacacla

Tree Physiology 8, pp. 381-389 (1991)

K. H. Johnson, B. C. Bongarten, L. R. Boring. University of Georgia, Athens, Ga.

817 Fuel Ethanol from Cellulosic Blomass

Science 251, pp. 1318-1323 (1991)

L. R. Lynd. Thayer School of Engineering, Dartmouth College, Hanover, N. H.

J. H. Cushman. Oak Ridge National Laboratory, Oak Ridge, Tenn.

R. J. Nichols. Ford Motor Company, Dearborn, Mich.

C. E. Wyman. National Energy Research Laboratory, Golden, Colo.

818 Blological Markers in AnImals and Plants to Establish Exposure to, and Effects of, Atmospheric Toxicants

Ecological Exposure and Effects of Airborne Toxic Chemicals: An Overview, ed. T. J. Moser, J. R. Baker, and D. T. Tingey, pp. 107-127 (Corvallis, Ore.: U.S. Environmental Protection Agency, 1991)

J. F. McCarthy, T. J. Tschaplinski. Oak Ridge National Laboratory, Oak Ridge, Tenn.

819 Disease and Insect Resistance: A Key to Successful Short Rotation Woody Crops Systems

Ames Forester 78, pp. 31-33 (1991)

H. S. McNabb, Jr., E. R. Hart, R. B. Hall. lowa State University, Ames, lowa 
820 A Field Trlal of Transgenic Hybrid Poplar Trees: Establishment and Growth Through The Second Season

Biological Monitoring of Genetically Engineered Plants and Microbes, ed. D. R.

MacKenzie and S. C. Henry, pp. 155-159 (Bethesda, Md.: Agricultural Research Institute, 1991)

H. S. McNabb, Jr., N. B. Klopfenstein, R. D. Hanna, R. B. Hall, E. R. Hart, S. A. Heuchelin, R. W. Thornbur. lowa State University, Ames, lowa

821 A Five-Year Study of Herbaceous Energy Crops

Proc., Energy from Biomass and Wastes XIV, ed. D. L. Klass, pp. 447-464 (Chicago, III.: Institute of Gas Technology, 1991)

D. J. Parrish, D. D. Wolf, W. L. Daniels, J. S. Cundiff, D. H. Vaughan. Virginia PolyTechnic Institute and State University, Blacksburg, Va.

822 Micro- and Cutting Propagation of Sllver Maple. I. Results with Adult and Juvenlle Propagules

J. Amer. Soc. Hort. Sci. 116, pp. 142-148 (1991)

J. E. Preece, C. A. Huetteman, W. C. Ashby, P. L. Roth. Southern Illinois University, Champagne, III.

\section{Energy from Blomass}

The Energy Sourcebook: a Guide to Technology, Resources and Policy, pp. 299-311

(New York: American Institute of Physics, 1991)

J. W. Ranney, J. H. Cushman. Oak Ridge National Laboratory, Oak Ridge, Tenn.

824 Carbon Storage and Recycling in Short-Rotation Energy Crops

Proc., Bioenergy and the Greenhouse Effect, ed. C. P. Mitchell, pp. 39-60 (Stockholm, Sweden: International Energy Agency and National Energy Administration of Sweden, 1991)

J. W. Ranney, L. L. Wright, C. P. Mitchell. Oak Ridge National Laboratory, Oak Ridge, Tenn.

825 Woody Blomass Production Costs in the United States: An Economic Summary of Commerclal Populus Plantation Systems

Proc., Energy from Biomass and Wastes XIV, ed. D. L. Klass, pp. 359-369 (Chicago, Ill.: Institute of Gas Technology, 1991)

C. H. Strauss. Pennsytvania State University, University Park, Pa.

L. L. Wright. Oak Ridge National Laboratory, Oak Ridge, Tenn.

826 Influence of Timing and Method of Harvest on Rapeseed Yield

J. Production Agriculture 4, pp. 266-272 (1991)

D. L. Thomas, M. A. Breve, P. L. Raymer. University of Georgia, Athens, Ga.

827 Blomass and Soll Nitrogen Relationships of a One-Year-Old Sycamore Plantation

Soil Sci. Am. J. 55, pp. 841-847 (1991)

T. J. Tschaplinski, R. J. Norby, D. E. Todd. Oak Ridge National Laboratory, Oak Ridge, Tenn.

D. W. Johnson. Desert Research Institute, Reno, Nev.

828 Physiological Indicators of Nitrogen Response in Short Rotation Sycamore Plantations. I. $\mathrm{CO}_{2}$ Assimilation, Photosynthetlc Plgments, and Soluble Carbohydrates

Physiol. Plant. 82, pp. 117-126 (1991)

T. J. Tschaplinski, R. J. Norby. Oak Ridge National Laboratory, Oak Ridge, Tenn. 
829 Screening Herbaceous Lignocellulosic Energy Crops in Temperate Reglons of the United States

Bioresource Technology 36, pp. 247-252 (1991)

A. F. Turhollow. Oak Ridge National Laboratory, Oak Ridge, Tenn.

830 Windbreak Species Performance and Management Practlces as Reported by Montana and North Dakota Landowners

J. Soil and Water Conservation May-June, pp. 225-228 (1991)

G. A. Tuskan. Oak Ridge National Laboratory, Oak Ridge, Tenn.

K. Laughlin. University of Idaho, Sandpoint, Idaho

831 Role of New Wood Energy Crops in Mitigation of Fossll $\mathrm{CO}_{2}$ EmIssions

Proc., 1990 Conference on Biomass for Utility Applications, pp. 87-112 (Palo Alto, Calif.:

Electric Power Research Institute, 1991)

L. L. Wright. Oak Ridge National Laboratory, Oak Ridge, Tenn.

832 The Economic Vlabillty of Short Rotation Woody Crops

Policy Implications of Greenhouse Warming Report of the Mitigation Panel. Appendix H:

Biomass, pp. H-1-H-7 (Washington, D. C.: National Academy Press, 1991)

L. L. Wright. Oak Ridge National Laboratory, Oak Ridge, Tenn.

833 Herbaceous Energy Crops Program: Annual Progress Report for FY 1988 ORNL-6639 (November 1990)

A. F. Turhollow, J. H. Cushman, J. W. Johnston. Oak Ridge National Laboratory, Oak

Ridge, Tenn.

834 Screening of Herbaceous Specles for Energy Crop Production. FInal Report 1985-1990

ORNL/Sub/85-27411/5 (November 1990)

N. Wright. Geophyta, Vickery, Ohio

835 Evaluation of Potentlal Herbaceous Blomass Crops on Marginal Crops

Lands: 2) Economic Potential. Final Report 1985-1989

ORNL/Sub/85-27412/5\&P2 (November 1990)

C. L. Dobbins, P. Preckel, A. Mdafri, J. Lowenberg-DeBoer, D. Stucky. Purdue

University, West Lafayette, Ind.

836 Screening and Selection of Herbaceous Species for Biomass Production In the MIdwest/Lake States. Final Report 1985-1989

ORNL/Sub/85-27410/5 (November 1990)

R. A. Pielfer, G. W. Fick, D. J. Lathwell, C. Maybee. New York State College of Agriculture and Life Sciences, Comell University, Ithaca, N.Y.

837 Short Rotation Woody Crops Program: Annual Progress Report for 1989 ORNL-6625 (August 1990)

L. L. Wright, A. R. Ehrenshaft. Oak Ridge National Laboratory, Oak Ridge, Tenn.

838 Modifying Woody Plants for Efficlent Conversion to Liquld and Gaseous Fuels

ORNL/Sub/88-SC006/1 (July 1990)

R. J. Dinus, D. R. Dimmel, R. P. Feirer, M. A. Johnson, E. W. Malcolm. Institute of Paper

Science and Technology, Atlanta, Ga. 
839 Evaluation of Potentlal Herbaceous Blomass Crops on Marginal Crop Lands: 1) Agronomic Potential. Final Report 1985-1989 ORNL/Sub/85-27412/5\&P1 (July 1990)

J. H. Cherney, K. D. Johnson, J. J. Volenec, E. J. Kladivko, D. K. Greene. Department of Agronomy, Purdue Univ., West Lafayette, Ind.

840 Evaluation of the Potential for Using Old-Fleld Vegetation as an Energy Feedstock: Blomass Yleld, Chemical Composition, Environmental Concerns, and Economics ORNLTM-11615 (July 1990)

J. W. Johnston, Jr. Oak Ridge National Laboratory, Oak Ridge, Tenn.

841 Selection and Improvement of Herbaceous Energy Crops for the Southeastern USA. Final Report on a Fleld and Laboratory Research Program for the Period March 15, 1985 to March 14, 1990 ORNL/Sub/85-27409/5 (July 1990)

D. I. Bransby, S. E. Sladden, D. D. Kee. Dept. of Agronomy and Soils, Auburn University, Auburn University, Ala.

842 Perennial Species for Optimum Production of Herbaceous Biomass in the Pledmont. Final Report 1985-1989

ORNL/Sub/85-27413/5 (July 1990)

D. J. Parrish, D. D. Wolf, W. L. Daniels, D. H. Vaughan, J. S. Cundiff. Virginia Polytechnic Institute and State University, Blacksburg, Va.

843 Improving Rapeseed Production Practices In the Southeastern United States

ORNL/Sub/86-91324/1 (April 1990)

D. L. Thomas, M. A. Breve, P. L. Raymer, N. A. Minton, D. R. Sumner. University of Georgia, Coastal Plain Experiment Station, Tifton, Ga.

$844 \mathrm{CO}_{2}$ Emissions from Production and Combustion of Fuel Ethanol from Corn ORNLTM-11180 (May 1990)

G. Marland, A. Turhollow. Oak Ridge National Laboratory, Oak Ridge, Tenn.

845 International Transfer of Agnus, Populus, and Cellos Biomass 22, pp. 49-62 (1990)

A. Ager, N. E. Nordh, S. Ledin, M. Ostry, M. Carlson, A. Ronnberg-Wastljung. USDA

Forest Service, North Central Forest Experiment Station, Rhinelander, Wis.

846 Mechanization of the Operational Aspects of Short-Rotation Forestry Biomass 22, pp. 123-33 (1990)

N. S. Christopherson, J. A. Mattson. USDA Forest Service, North Central Forest Experiment Station, Rhinelander, Wis.

847 Chemical Control of Adventitious Root Formation In Cuttings PGRSA Quarterly 18, pp. 1-17 (1990)

T. D. Davis, B. E. Haissig. USDA Forest Service, North Central Forest Experiment Station, Rhinelander, Wis.

848 Evaluation of Agnus Species and Hybrids

Biomass 22, pp. 21-34 (1990)

R. B. Hall, D. Burgess. lowa State University, Ames, lowa 
849 Genetic Varlation and Productivity of Populus trichocarpa and its Hybrids. IV. Performance in Short-Rotation Copplce

Can. J. For. Res. 20, pp. 1257-64 (1990)

P. E. Heilman. Washington State University, Puyallup, Wash.

R. F. Stettler. University of Washington, Seattle, Wash.

850 Valldating the Reglonal Applicabllity of a Whole-Plant Ecophysiological Growth Process Model of Juvenlle Poplar Proceedings, Forest Simulation Systems, ed. L. C. Wensel and G. S. Biging, pp. 97-106 (University of California, 1990)

G. E. Host, H. M. Rauscher. USDA Forest Service, North Central Forest Experiment Station, Rhinelander, Wis.

851 Fuel Ethanol from Cellulosic Blomass

Science 251, pp. 1318-23 (1990)

L. R. Lynd. Thayer School of Engineering, Dartmouth College, Hanover, N.H.

J. H. Cushman. Oak Ridge National Laboratory, Oak Ridge, Tenn.

R. J. Nichols. Ford Motor Company, Dearborn, Mich.

C. E. Wyman. Solar Energy Research Institute, Golden, Colo.

852 The Microcomputer Sclentific Serles \#6: The ECOPHYS User's Manual General Technical Report NC-141 (St. Paul, Minn.: U.S. Forest Service, North Central Forest Experiment Station, 1990)

G. E. Host, H. M. Rauscher, J. G. Isebrands, R. E. Dickson, T. R. Crow, D. A. Michael. USDA Forest Service, North Central Forest Experiment Station, Rhinelander, Wis.

D. I. Dickmann. Michigan State University, East Lansing, Mich.

853 Accelerating Energy Crop Growth vla Genetic Techniques Energy from Biomass and Wastes XIII, pp. 397-424 (Chicago: Institute of Gas Technology, 1990)

P. A. Layton, L. L. Wright, T. W. Doyle, J. W. Ranney, J. H. Cushman, A. F. Turhollow. Oak Ridge National Laboratory, Oak Ridge, Tenn.

854 Economic Evaluations of Optimum Rotation Age for SRIC Plantations Energy from Biomass and Wastes XIII, pp. 295-307 (Chicago: Institute of Gas Technology, 1990)

C. H. Strauss, S. C. Grado, P. R. Blankenhorn, T. W. Bowersox. The Pennsylvania State University, University Park, $\mathrm{Pa}$.

855 Commerclalization of Short-Rotation Intensive Culture Tree Production in North America

Energy from Biomass and Wastes XIII, pp. 309-29 (Chicago: Institute of Gas Technology, 1990)

L. L. Wright. Oak Ridge National Laboratory, Oak Ridge, Tenn.

856 ATP Concentrations In PInus banksiana Cuttings During Adventitious Rooting

J. Plant Physiol. 136, pp. 499-502 (1990)

B. E. Haissig. USDA Forest Service, North Central Forest Experiment Station, Rhinelander, Wis.

857 Reduced Irradlance and Applled AuxIn Influence Carbohydrate Relations in Pinus banksiana Cuttings During Propagation

Physiologia Plantanum 78, pp. 455-61 (1990)

B. E. Haissig. USDA Forest Service, North Central Forest Experiment Station, Rhinelander, Wis. 
858 Photosynthesis Patterns During the Establishment Year Within two Populus Clones

Tree Physiology 6, pp. 11-27 (1990)

D. A. Michael, J. G. Isebrands, N. D. Nelson. USDA Forest Service, North Central Forest Experiment Station, Rhinelander, Wis.

D. I. Dickmann. Michigan State University, East Lansing, Mich.

859 Minimizing Disease Injury to Hybrid Poplars

J. Environ. Hort. 8, pp. 96-98 (1990)

M. E. Ostry. USDA Forest Service, North Central Forest Experiment Station,

Rhinelander, Wis.

H. S. McNabb, Jr. lowa State University, Ames, lowa

860 Cost Parameters Affecting Multiple Rotation SRIC Blomass Systems Appl. Biochem. Biotech. 24/25, pp. 721-33 (1990)

C. H. Strauss, S. C. Grado, P. R. Blankenhorn, T. W. Bowersox. The Pennsylvania State University, University Park, $\mathrm{Pa}$.

861 Woody Biomass Production Costs in the United States: An Economic Summary of Commerclal Populus Plantation Systems

Solar Energy 45, pp. 105-10 (1990)

C. H. Strauss. The Pennsylvania State University, University Park, Pa.

L. L. Wright. Oak Ridge National Laboratory, Oak Ridge, Tenn.

862 A Review of Blomass Quallty Research Relevant to the Use of Poplar and WIIlow for Energy Conversion

Biomass 21, pp. 163-88 (1990)

W. A. Kenney. University of Toronto, Ontario, Canada

L. Sennerby-Forsse. Swedish University of Agricultural Sciences, Uppsula, Sweden

P. A. Layton. Oak Ridge National Laboratory, Oak Ridge, Tenn.

863 Economic Evaluations for Short-Rotation Blomass Production Systems

Biomass 22, pp. 135-44 (1990)

D. C. Lothner. USDA Forest Service, North Central Forest Experiment Station,

Rhinelander, Wis.

864 Coppicing Success of Young Eucalyptus saligna in Hawall Biomass 23, pp. 137-48 (1990)

T. W. Bowersox. The Pennsylvania State University, University Park, Pa.

T. H. Schubert, R. F. Strand. USDA Forest Service, Pacific Northwest Forest Experiment

Station, Portland, Ore.

C. D. Whitesell. BioEnergy Development Corp., Hilo, Hawaii

865 National Winter Rapeseed Variety Trial 1988-89

Miscellaneous Series No. 130 (Moscow, Idaho: University of Idaho, 1990)

K. A. Mahler, D. L. Auld, comps. University of Idaho, Moscow, Idaho

866 Blotechnology in Blomass Crop Production. The Relationship of Blomass Production and Plant Genetic Englneering

ORNL/M-978 (December 1989)

D. E. Harry. University of Illinois Urbana-Champaign, Urbana, III.

R. R. Sederoff. North Carolina State University, Raleigh, N.C. 
867 Short Rotation Woody Crops Program: Annual Progress Report for 1988 ORNL-6594 (October 1989) L. L. Wright, T. W. Doyle, P. A. Layton, J. W. Ranney. Oak Ridge National Laboratory, Oak Ridge, Tenn.

868 Improved Conversion of Herbaceous Blomass to Blofuels: Potential for Modification of Key Plant Characteristics. Final Report on a Literature Review and Survey ORNL/Sub/88-SC011/1 (October 1989)

S. E. Sladden, D. I. Bransby. Aubum University, Auburn, Ala.

869 The SRWCP Database Management System: Users Guide, Data Definitions, and Source Code

ORNLTM-10820 (February 1989)

A. R. Ehrenshaft, L. L. Wright. Oak Ridge National Laboratory, Oak Ridge, Tenn.

870 Short Rotation Woody Crops Program Publications and Presentations ORNLTM-10848 (February 1989)

A. R. Ehrenshaft. Oak Ridge National Laboratory, Oak Ridge, Tenn.

871 Herbaceous Energy Crops Program: Annual Progress Report for FY 1987 ORNL-6514 (January 1989)

J. H. Cushman, A. F. Turhollow, J. W. Johnston. Oak Ridge National Laboratory, Oak

Ridge, Tenn.

872 Quick Estimates of Root Length, Using a Video Image Analyzer Canadian Journal of Forest Research 19, pp. 335-40 (1989)

M. Cunningham. University of Tennessee, Knoxville, Tenn.

M. B. Adams, R. J. Luxmoore, W. M. Post, D. L. DeAngelis. Oak Ridge National Laboratory, Oak Ridge, Tenn.

873 No-TIII Establlshment of Perennlal, Warm-Season Grasses for Blomass Production Biomass 20, pp. 209-17 (1989)

D. D. Wolf, D. J. Parrish, W. L. Daniels, J. R. McKenna. Virginia Polytechnic Institute and State University, Blacksburg, Va.

874 Herbaceous Crops on Marginal Sites Erosion and Economics Biomass 29, pp. 199-208 (1989)

D. H. Vaughan, J. S. Cundiff, D. J. Parrish. Virginia Polytechnic Institute and State University, Blacksburg, Va.

875 Allozyme Varlation in Black Locust (Robinia pseudoacacla) Can. J. For. Research 19, pp. 471-79 (1989)

S. E. Surles, J. L. Hamrick, B. C. Bongarten. University of Georgia, Athens, Ga.

876 Shoot Culture Dynamics of Six Populus Clones

Tree Physiology 5, pp. 219-27 (1989)

J. C. Sellmer, B. E. Haissig. USDA Forest Service, North Central Forest Experiment Station, Rhinelander, Wis.

B. H. McCown. University of Wisconsin, Madison, Wis.

877 Species Screening and Blomass Trials of Woody Plants in the Seml-Arid Southwest United States

Biomass 18, pp. 15-29 (1989)

R. D. Kirmse, J. T. Fisher. Energy/Development International, Washington, D.C. 
878 Physlological, Morphological and Anatomical Components of Hybrid Vigor In Populus

Structural and Functional Responses to Environmental Stresses, ed. K. H. Kreeb, H. Richter, and T. M. Hinckley, pp. 199-217 (The Hague, The Netherlands: SPB Academic Publishing bV, 1989)

T. M. Hinckley, R. Ceulemans, J. M. Dunlap, A. Figliola, P. E. Heilman, G. ScarasciaMugnozza, P. J. Schulte, B. Smith, R. F. Stettler, E. Van Volkenburg, B. M. Wiard. University of Washington, Seattle, Wash.

J. G. Isebrands. USDA Forest Service, North Central Experiment Station, Rhinelander, Wis.

879 Using N2-fixing Albizla to Increase Growth of Eucalyptus Plantations in Hawall

Forest Science 35, pp. 64-75 (1989)

D. S. DeBell, C. D. Whitesell, T. H. Schubert. USDA Forest Service, Pacific Northwest Station, Portland, Ore.

880 Blomass Production from Selected Herbaceous Species in the Southeastern USA

Biomass 20, pp. 187-97 (1989)

D. I. Bransby, C. Y. Ward, P. A. Rose, S. E. Sladden, D. D. Kee. Aubum University, Auburn, Ala.

881 The Potential of Vegetable Oll as an Alternate Source of Liquid Fuel for Agriculture in the Pacific Northwest VI

Miscellaneous Series No. 121 (Moscow, Idaho: University of Idaho, 1989)

D. L. Auld, R. A. Korus, C. L. Peterson. University of Idaho, Moscow, Idaho

882 Ethanol Production and the Environment

Energy 14, pp. 451-68 (1989)

D. B. Hunsaker, Jr., J. F. McBrayer. Oak Ridge National Laboratory, Oak Ridge, Tenn.

J. L. Elmore. PEER Consultants, Oak Ridge, Tenn.

883 Photosynthetic Reinvigoration of Leaves Following Shoot Decapitation and Accelerated Growth of Copplce Shoots

Physiol. Plant. 75, pp. 157-65 (1989)

T. J. Tschaplinski. Automated Sciences Group, Inc., Oak Ridge, Tenn.

T. J. Blake. University of Toronto, Toronto, Ontario, Canada

884 The Role of Sink Demand in Carbon Partitioning and Photosynthetic Reinvigoration Following Shoot Decapltation

Physiol. Plant. 75, pp. 166-73 (1989)

T. J. Tschaplinski. Automated Sciences Group, Inc., Oak Ridge, Tenn.

T. J. Blake. University of Toronto, Toronto, Ontario, Canada

885 Comparisons Among Populus Clones and Intensive Culture Conditions Using an Energy Conversion Model

Forest Ecology and Management 27, pp. 129-47 (1989)

J. J. Landsberg. Commonwealth Scientific and Industrial Research Organization, Australia

L. L. Wright. Oak Ridge National Laboratory, Oak Ridge, Tenn. 
886 Water Stress Tolerance and Late-Season Organic Solute Accumulation in Hybrid Poplar

Can J. Bot. 67, pp. $1681-88$ (1989)

T. J. Tschaplinski. Automated Sciences Group, Inc., Oak Ridge, Tenn.

T. J. Blake. University of Toronto, Toronto, Ontario, Canada

887 Correlation Between Early Root Production, Carbohydrate Metabolism, and Subsequent Dry Matter Production in Hybrid Poplar

Can. J. Bot. 67, pp. $2168-74$ (1989)

T. J. Tschaplinski. Automated Sciences Group, Inc., Oak Ridge, Tenn.

T. J. Blake. University of Toronto, Toronto, Ontario, Canada

888 Commerclalization of Short-Rotation Intensive Culture Tree Production In North America

Energy from Biomass and Wastes XII, ed. D. L. Klass, pp. 261-74 (Chicago: Institute of Gas Technology, 1989)

L. L. Wright. Oak Ridge National Laboratory, Oak Ridge, Tenn.

889 Water Relations and Photosynthetic Capacity as Determinants of Productivity in Hybrid Poplar Cultivars

Can. J. Bot. 67, pp. 1689-97 (1989)

T. J. Tschaplinski. Automated Sciences Group, Inc., Oak Ridge, Tenn.

T. J. Blake. University of Toronto, Toronto, Ontario, Canada 


\section{BIOTECHNOLOGY}

890 Sustained Degradation of n-Pentane and Isobutane in Gas-Phase Bloreactor

Biotechnol. Lett. 15(6), pp. 633-36 (June 1993)

B. H. Davison, J. E. Thompson. Oak Ridge National Laboratory, Oak Ridge, Tenn.

891 Advanced Bloprocessing Concepts: Technology Needs and R\&D Opportunities Prellminary Assessment

ORNLM-2629 (January 15, 1993)

B. H. Davison, C. D. Scott, T. C. Scott. Oak Ridge National Laboratory, Oak Ridge, Tenn.

892 Continuous Direct Solvent Extraction of Butanol in a Fermenting Fluidlzed-Bed Bloreactor with Immobllized Clostridium acetobutylicum Appl. Biochem. Biotech. 39/40, pp. 415-26 (1993)

B. H. Davison, J. E. Thompson. Oak Ridge National Laboratory, Oak Ridge, Tenn.

893 Advanced Bioreactors for Enhanced Production of Chemicals pp. 304-307 in Preprints: 205th American Chemical Society National Meeting, Denver, March 28-April 2, 1993, 38(2) (American Chemical Society, 1993)

B. H. Davison, C. D. Scott. Oak Ridge National Laboratory, Oak Ridge, Tenn.

894 Three Immobilized-Cell Columnar Bloreactors for Enhanced Production of Commodity Chemicals

Proceedings of the First Biomass Conference of the Americas-Energy, Environment, Agriculture, and Industry, August 30-September 2, 1993, Burlington, Vermont (Golden, Colo.: National Renewable Energy Laboratory, 1993)

B. H. Davison, C. D. Scott, E. N. Kaufman. Oak Ridge National Laboratory, Oak Ridge, Tenn.

895 A Proposed Blparticle Fluidlzed-Bed for Lactic Acld Fermentation and Simultaneous Adsorption

Biotechnology and Bioengineering 39(3), pp. 365-68 (1992)

B. H. Davison, C. D. Scott. Oak Ridge National Laboratory, Oak Ridge, Tenn.

896 Simultaneous Fermentation and Separation of Lactic Acid in a Biparticle Fluldized Bed Bloreactor

Appl. Biochem. and Biotech., 34/35, pp. 431-39 (1992)

B. H. Davison, J. E. Thompson. Oak Ridge National Laboratory, Oak Ridge, Tenn.

897 Technoeconomic Evaluation of the Extractive Fermentation of Butanol as a Guide to Research in This Area of Blotechnology ORNL/TM-11851 (September 1991)

R. M. Busche. Bio En-Gene-Er Assoc., Inc., Wilmington, Del.

898 The UItimate Ethanol: Technoeconomic Evaluation of Ethanol Manufacture, Comparing Yeast vs Zymomonas Bacterium Fermentatlons ORNLTM-11852 (August 1991)

R. M. Busche. Bio En-Gene-Er Associates, Inc., Wilmington, Del.

C. D. Scott, B. H. Davison. Oak Ridge National Laboratory, Oak Ridge, Tenn.

L. R. Lynd. Dartmouth College, Hanover, N.H. 
899 Phase Holdup and Dispersion In a Three-Phase Fluidized-Bed Bloreactor with Low-Density Gel Beads

Annals of the New York Academy of Sciences 589, pp. 670-77 (1990)

B. H. Davison. Oak Ridge National Laboratory, Oak Ridge, Tenn.

900 Use of Immobllized Mlcroblal Membrane Fragments to Reduce Oxygen Content and Enhance the Acetone-Butanol Fermentation Biotechnol. Prog. 6, pp. 210-13 (1990)

F. Godia. Unitat d'Enginyeria Quimica, Universitat Autonoma de Barcelona, Spain

H. I. Adler. Oak Ridge Associated Universities, Oak Ridge, Tenn.

B. H. Davison, C. D. Scott. Oak Ridge National Laboratory, Oak Ridge, Tenn.

901 Gas Holdup in Three-Phase Immobillzed Cell Bloreactors

Appl. Biochem. Biotech. 24/25, pp. 485-96 (1990)

R. Bajpai. University of Missouri-Columbia, Columbia, Mo.

J. E. Thompson, B. H. Davison. Oak Ridge National Laboratory, Oak Ridge, Tenn.

902 Corn Products as Chemical Feedstocks: The Corn Refinery

Proceedings First Annual Corn Utilization Conference, St. Louis, Mo., June 11-12, 1987, pp. 286-99 (National Com Growers Association, 1989)

C. D. Scott. Oak Ridge National Laboratory, Oak Ridge, Tenn.

903 Dispersion and Holdup In a Three-Phase Fluldized-Bed Bloreactor Appl. Biochem. Biotechnol. 20-21, pp. 449-60 (Clifton, N.J.: Humana Press, 1989)

B. H. Davison. Oak Ridge National Laboratory, Oak Ridge, Tenn.

904 Solute Diffusion In Blocatalyst Gel Beads Containing Blocatalysts and Other Additives

Enzyme Microb. Technol. 11, pp. 258-63 (1989)

C. D. Scott, J. A. Woodward, J. E. Thompson. Oak Ridge National Laboratory, Oak Ridge, Tenn. 


\title{
CONTINUOUS CHROMATOGRAPHY IN MULTICOMPONENT SEPARATIONS
}

\author{
905 Advanced Techniques for Energy-Efficlent Industrlal-Scale Continuous \\ Chromatography \\ ORNLTTM-11282 (November 1989) \\ J. P. DeCari II. Dow Chemical Company, Midland, Mich. \\ G. Carta. University of Virginia, Charlottesville, Va. \\ C. H. Byers. Oak Ridge National Laboratory, Oak Ridge, Tenn.
}

906 Large-Scale Separation of Amino Acids by Continuous Displacement Chromatography

DOE/OR/21400-T468* (October 1989)

J. P. DeCarli II. Dow Chemical Company, Midland, Mich.

G. Carta. University of Virginia, Charlottesville, Va.

C. H. Byers. Oak Ridge National Laboratory, Oak Ridge, Tenn.

907 An Economic and Energy Evaluation of the Replacement of Conventional Technology with Continuous Chromatography in the Dump Leaching of Copper Ores DOE/OR/21400-T35* (February 1989)

C. H. Byers, J. M. Begovich. Oak Ridge National Laboratory, Oak Ridge, Tenn. J. M. Holmes. JMH Associates, Knoxville, Tenn.

908 Novel Applications of Continuous Annular Chromatography: Separation of Sugars

New Directions in Sorption Technology, ed. G. E. Keller II and R. T. Yang, Pp. 342-49

(Stoneham, Mass.: Buttersworth, 1989)

A. J. Howard. University of Florida, Gainesville, Fla.

G. Carta. University of Virginia, Chariottesville, Va.

C. H. Byers. Oak Ridge National Laboratory, Oak Ridge, Tem.

909 Pllot-Scale Studles of Sugar Separations by Continuous Chromatography Appl. Biochem. Biotechnol. 20-21, pp. 635-54 (Clifton, N.J.: Humana Press, 1989)

C. H. Byers, W. G. Sisson. Oak Ridge National Laboratory, Oak Ridge, Tenn.

J. P. DeCarli, G. Carta. University of Virginia, Charlottesville, Va.

910 The Use of Gradlent Elution In Optimizing Continuous Annular Ion Exchange Chromatography with Applications to Metal Separations Ion Exchange for Industry, Proceedings IEX'88, Cambridge, Great Britain, July 17-22, 1988, ed. M. Streat, pp. 424-42 (Chichester: E. Horwood, 1989)

C. H. Byers, W. G. Sisson. Oak Ridge National Laboratory, Oak Ridge, Tenn.

J. P. DeCarli. University of Virginia, Charbttesville, Va.

911 Separation of Metals by Continuous Annual Chromatography with Step Elution

Chem. Eng. Comm. 79, pp. 207-27 (1989)

J. P. DeCarli, G. Carta. University of Virginia, Charlottesville, Va.

C. H. Byers, W. G. Sisson. Oak Ridge National Laboratory, Oak Ridge, Tenn.

\footnotetext{
"Available from the National Technical Information Service, U.S. Department of Commerce, 5285

Port Royal Road, Springfield, Virginia 22151.
} 



\section{SENSORS FOR ELECTROLYTIC CELLS}

912 Temperature Measurement by Observation of the Raman Spectrum of Dlamond Appl. Spectrosc. 46, pp. 375-77 (1992)

S. Dai, J. P. Young, G. M. Begun. Oak Ridge National Laboratory, Oak Ridge, Tenn. G. Mamantov. University of Tennessee, Knoxville, Tenn.

913 Measurement of Radical Cation UV-Visible Spectrum in a Polycrystalline Freon Matrix at Liquid Nitrogen Temperature by Diffuse Reflectance Spectroscopy Appl. Spectrosc. 46, pp. 377-78 (1992)

S. Dai, J. P. Young. Oak Ridge National Laboratory, Oak Ridge, Tenn.

G. Mamantov, J. T. Wang, F. Williams. University of Tennessee, Knoxville, Tenn.

914 A New Sample Cell for Diffuse Reflectance IR Spectroscopy of Alr-Sensitive Solld Samples

Appl. Spectrosc. 45, pp. 1056-58 (1991)

S. Dai, J. P. Young. Oak Ridge National Laboratory, Oak Ridge, Tenn.

G. Mamantov. University of Tennessee, Knoxville, Tenn. 



\section{HYDROPOWER ENVIRONMENTAL MITIGATION}

915 Status of Fish Passage Facilities at Non-federal Hydropower Projects Fisheries 18(7), p. 4 (July 1993)

G. F. Cada, M. J. Sale. Oak Ridge National Laboratory, Oak Ridge, Tenn.

916 Benefits of Fish Passage and Protection Measures at Hydroelectrlc Projects Waterpower '93, Proceedings of the International Conference on Hydropower, Nashville, Tenn., August 10-13, 1993 (New York: American Society of Civil Engineers, 1993) G. F. Cada, D. W. Jones. Oak Ridge National Laboratory, Oak Ridge, Tenn.

917 Standardizing in-Stream Flow Requirements at Hydropower Projects in the Cascade Mountalns, Washington

Waterpower '93, Proceedings of the International Conference on Hydropower, Nashville, Tenn., August 10-13, 1993 (New York: American Society of Civil Engineers, 1993)

I. M. Smith. Oak Ridge Institutes for Science and Education, Oak Ridge, Tenn.

M. J. Sale. Oak Ridge National Laboratory, Oak Ridge, Tenn.

918 Environmental Requirements at Hydroelectric Power Projects

Book of Abstracts, 205th American Chemical Society National Meeting, Denver, March

28-April 2, 1993 (1993)

J. E. Francfort. EG\&G Idaho, Idaho Falls, Idaho

G. F. Cada. Oak Ridge National Laboratory, Oak Ridge, Tenn.

919 Use of Rapld Bioassessment Approaches to Examine Benthic Macroinvertebrate Responses to Hydropower Flow Diversions

Bull. North American Benthological Society 10(1), p. 113 (1993)

G. F. Cada. Oak Ridge National Laboratory, Oak Ridge, Tenn

920 Use of a Reservoir Water Quality Model to Simulate Global CIImate Change Effects on Fish Habltat

Clim. Change 20, pp. 277-96 (1992)

L. H. Chang, S. F. Railsback. Oak Ridge National Laboratory, Oak Ridge, Tenn.

R. T. Brown. Jones \& Stokes Assoc., Sacramento, Calif.

921 Environmental Mitigation at Hydroelectric Projects. Volume 1. Current Practices for Instream Flow Needs, Dissolved Oxygen, and Fish Passage

DOE/IE-10360* (December 1991)

M. J. Sale, G. F. Cada, L. H. Chang, S. W. Christensen, S. F. Railsback. Oak Ridge

National Laboratory, Oak Ridge, Tenn.

J. E. Francfort, B. N. Rinehart, G. L. Sommers. Idaho National Engineering Laboratory, Idaho Falls, Idaho

922 A New Look at Environmental Mitigation Practices

Hydro Review, pp. 58-66 (July 1991)

M. J. Sale, S. F. Railsback. Oak Ridge National Laboratory, Oak Ridge, Tenn.

923 Environmental Impacts of Increased Hydroelectric Development at Existing Dams ORNLTM-11673 (April 1991)

S. F. Railsback, G. F. Cada, C. H. Petrich, M. J. Sale, J. A. Shaakir-Ali, J. A. Watts, J. W. Webb. Oak Ridge National Laboratory, Oak Ridge, Tenn.

\footnotetext{
* Available from the National Technical Information Service, U.S. Department of Commerce, 5285 Port Royal Road, Springfield, Virginia 22161.
} 
924 Review of Mitigation Methods for Fish Passage, Instream Flows, and Water Quallty Waterpower '91, Proceedings of the International Conference on Hydropower, Denver, Colorado, July 24-26, 1991, ed. D. D. Darling, 1, pp. 209-18 (New York: American Society of Civil Engineers, 1991)

S. F. Railsback, G. F. Cada, L. H. Chang, M. J. Sale. Oak Ridge National Laboratory, Oak Ridge, Tenn.

925 Effects of Hydroelectric Turbine Passage on Flsh Early Life Stages

Waterpower '91, Proceedings of the International Conference on Hydropower, Denver, Colorado, July 24-26, 1991, ed. D. D. Darling, pp. 318-26 (New York: American Society of Civil Engineers, 1991)

G. F. Cada. Oak Ridge National Laboratory, Oak Ridge, Tenn.

926 Distribution and Stablilty of Potentlal Salmonid Spawning Gravels In Steep Boulder-Bed Streams of the Eastern Slerra Nevada

Transactions of the American Fisheries Society 120(2), pp. 177-86 (1991)

G. M. Kondolf, G. F. Cada, M. J. Sale. Oak Ridge National Laboratory, Oak Ridge, Tenn.

T. Felando. INYO National Forest, Bishop, Calif.

927 Improving the Assessment of Instream Flow Needs for Fish Populations

Waterpower '91, Proceedings of the International Conference on Hydropower, Denver, Colorado, July 24-26, 1991, ed. D. D. Darling, 1, pp. 76-84 (New York: American Society of Civil Engineers, 1991)

M. J. Sale. Oak Ridge National Laboratory, Oak Ridge, Tenn.

R. G. Otto. R. G. Otto \& Associates, Arlington, Va.

928 A Review of Studles Relating to the Effects of Propeller-Type Turbine Passage on Fish Early Llfe Stages

North American Journal of Fisheries Management 10, pp. 418-26 (1990)

G. F. Cada. Oak Ridge National Laboratory, Oak Ridge, Tenn. 


\section{ENVIRONMENTAL CONTROL TECHNOLOGY}

Study of Solar Assisted Thermoelectric Technology for Automoblle Air Conditioning J. Solar Energy Eng. 115(4), p. 200 (November 1993)

V. C. Mei, F. C. Chen. Oak Ridge National Laboratory, Oak Ridge, Tenn.

B. Mathiprakasam, P. Heenan. Midwest Research Institute, Kansas City, Mo.

930 Heating, Ventllation, and Air Conditioning Systems

Proceedings of the Annual Automotive Technology Development Contractors'

Coordination Meeting, Dearbom, Mich., Nov. 2-5, 1992, pp. 609-16 (Warrendale, Pa.:

Society of Automotive Engineers, May 1993)

D. M. Kyle. Oak Ridge National Laboratory, Oak Ridge, Tenn.

R. A. Sullivan. Office of Energy Efficiency and Renewable Energy, Department of Energy, Washington, D. C.

931 The Oak Ridge National Laboratory Automobile Heat Pump Model: User's Guide ORNLCON-359 (May 1993)

D. M. Kyle. Oak Ridge National Laboratory, Oak Ridge, Tenn.

$932 \quad$ R-134a Liquid Over-Feeding Moblle Air Conditioning System

Proceedings Vehicle Thermal Management Systems, Columbus, Ohio, March 29-April 1, 1993, SAE P-263 (Warrendale, Pa.: Society of Automotive Engineers, 1993)

V. C. Mei, D. M. Kyle, F. C. Chen. Oak Ridge National Laboratory, Oak Ridge, Tenn.

933 An Automoblle Air Conditioner Design Model

Proceedings Vehicle Thermal Management Systems, Columbus, Ohio, March 29-April 1, 1993, SAE P-263, pp. 571-76 (Warrendale, Pa.: Society of Automotive Engineers, 1993)

D. M. Kyle, V. C. Mei, F. C. Chen. Oak Ridge National Laboratory, Oak Ridge, Tenn.

934 Alternative Non-CFC Moblle Alr Conditioning

ORNL/CON-335 (September 1992)

V. C. Mei, F. C. Chen, D. M. Kyle. Oak Ridge National Laboratory, Oak Ridge, Tenn. 



\section{CONTINUOUS FIBER CERAMIC COMPOSITE TECHNOLOGY}

935 Modeling the Thermal Conductivity of Fiber-Reinforced Ceramic Composttes Ceramic. Engr. \& Sci. Proc. 14(9/10), p. 1058 (September 1993)

S. C. Beecher, R. B. Dinwiddie. Oak Ridge National Laboratory, Oak Ridge, Tenn.

936 Influence of Fiber Coatings on the Oxidation of Fiber-Relnforced SIC Composites Ceramic Engineering and Science Proceedings July-August 1993. 17th Annual

Conference on Composites and Advanced Ceramic Materials 14(7/8), part 1, pp. 358-66 (Westerville, Ohio: American Ceramic Society, 1993)

P. F. Tortorelli, L. Riester, R. A. Lowden. Oak Ridge National Laboratory, Oak Ridge, Tenn.

S. Nijhawan. Coe College, Cedar Rapids, lowa

937 Development of an Interfacial Test System for the Determination of Interfacial Properties in Fiber Reinforced Ceramic Composites

Ceramic Engineering and Science Proceedings July-August 1993. 17th Annual

Conference on Composites and Advanced Ceramic Materials 14(7/8), part 1, pp. 156-67 (Westerville, Ohio: American Ceramic Society, 1993)

A. A. Wereszczak, M. K. Ferber, R. A. Lowden. Oak Ridge National Laboratory, Oak Ridge, Tenn.

938 The Relative Residual Fiber DIsplacement After Indentation Loading and Unloading of Fiber-Relnforced Ceramic Composites

J. Mater. Sci. 28(8), pp. 2227-32 (April 15, 1993)

C. H. Hsueh, M. K. Ferber, A. A. Wereszczak. Oak Ridge National Laboratory, Oak

Ridge, Tenn.

939 Evaluations of Residual Axial Stresses and Interfacial Friction in Nicalon Fiber-

Reinforced Macro-Defect-Free Cement Composites

J. Mater. Sci. 28, pp. 2551-56 (1993)

C. H. Hsueh, M. K. Ferber. Oak Ridge National Laboratory, Oak Ridge, Tenn.

940 Some Considerations of Two-Way Debonding During Flbre Pull-Out

J. Mater. Sci. Lett. 12, pp. 1933-36 (1993)

C. H. Hsueh, P. F. Becher. Oak Ridge National Laboratory, Oak Ridge, Tenn.

941 Continuous Fiber Ceramic Composite Program

Ceram. Bull. 70, p. 430 (1991)

M. A. Karnitz, D. F. Craig. Oak Ridge National Laboratory, Oak Ridge, Tenn.

S. L. Richlen. Office of Energy Efficiency and Renewable Energy, Department of Energy, Washington, D. C. 


\section{PHYSICAL CHEMISTRY OF GEOTHERMAL SYSTEMS}

942 Isoplestic Studles of $\mathrm{NaHSO}_{4}(\mathrm{aq})$. Thermodynamic Properties Joumal of Chemical Thermodynamics 25(1), pp. 99-110 (1993)

H. F. Holmes, R. E. Mesmer. Oak Ridge National Laboratory, Oak Ridge, Tenn.

943 The Activity-Composition Relationship of Oxygen and Hydrogen Isotopes In Aqueous Salt Solutions: I. Vapor-liquid Water Equilibration of Single Salt Solutions from 50 to $100^{\circ} \mathrm{C}$

Geochimica et Cosmochimica Acta 57(13), pp. 2797-2817 (1993)

J. Horita, D. J. Wesolowski, D. R. Cole. Oak Ridge National Laboratory, Oak Ridge, Tenn.

944 The Activity-Composition Relationship of Oxygen and Hydrogen Isotopes in Aqueous Salt Solutions: II. Vapor-Ilquid Water Equilibration of Mixed Salt Solutions from 50 to $100^{\circ} \mathrm{C}$ and Geochemical Implications Geochimica et Cosmochimica Acta 57(19), pp. 4703-11 (1993)

J. Horita, D. R. Cole, D. J. Wesolowski. Oak Ridge National Laboratory, Oak Ridge, Tenn.

945 Liquid-Vapor Partitioning of $\mathrm{HCl}(\mathrm{aq})$ to $350^{\circ} \mathrm{C}$

Geochimica et Cosmochimica Acta 57(1), pp. 1-7 (1993)

J. M. Simonson, D. A. Palmer. Oak Ridge National Laboratory, Oak Ridge, Tenn.

946 Aluminum Speciation and Equilibria in Aqueous Solution. III. Potentiometric Determination of the First Hydrolysis Constant of Aluminum(III) in Sodlum Chloride Solutions to $125^{\circ} \mathrm{C}$

Geochimica et Cosmochimica Acta 57(13), pp. 2929-38 (1993)

D. A. Palmer, D. J. Wesolowski. Oak Ridge National Laboratory, Oak Ridge, Tenn. 



\section{AUTHOR INDEX}

Abata, D. L. 453,467

Ackerman, J. L. 421

Adams, M. B. 872

Adibi, M. M. 600,609

Adler, H. I. 900

Ager, A. 845

Ahman, J. 347

Alam, M. S. 124

Alexander, D. J. 522, 543

Alexander, K. B. $676,702,715,722$, 723

Alexander, R. R. 802

Allard, L. F. 392, 694

Ally, M. R. 475, 476, 477, 478, 479, 480

Altman, J. 11, 20

Amin, K. E. 417

Anderson, I. C. 790

Anderson, R. W. 167, 173

Anderson-Batiste, G. J. 80

Angelini, P. 404, 438

Apsley, D. K. 799

Arendt, R. H. 700

Arimilli, R. V. 734, 745

Arnott, J. T. 813

Ashby, W. C. 772, 797, 803, 822

Auld, D. L. $804,805,865,881$

Avella, F. S. 317

Bajpai, R. 901

Baker, J. E. 658

Baldoni, J. G. 351, 399, 415

Bales, E. 222

Balzer, R. A. 235

Bandyopadhyay, B. P. 290

Barbieri, A. 533

Barito, M. O. 195

Barito, R. W. 195

Barnes, P. R. 593, 594, 598, 603, $604,614,616,618,619,625$, $628,635,636,638$

Barr, T. L. 554

Bates, C. H. 426

Baxter, V. D. $91,95,98,136$

Beal, D. J. 87

Beale, W. T. 153, 154

Beardsley, M. B. 305

Becher, P. F. 392, 404, 408, 438, 940

Beck, J. V. 224

Bednarczyk, P. J. 672, 683, 700

Beecher, S. C. 935
Begovich, J. M. 907

Begun, G. M. 385, 429, 912

Behi, M. 302, 326, 340

Bennett, A. I. 605

Bennett, M. N. 102

Berchowitz, D. M. 118

Berens, A. P. 382, 386

Bergman, L. B. 613,626

Berry, L. G. 63, 76, 82, 231, 232, $233,234,235,244,586,590$

Beschen, D. A. 238, 240, 243

Besmann, T. M. 518, 526, 698, 709

Beyer, M. A. 18, 240

Bhat, M. G. 751

Bible, D. W. 505, 527

Bingaman, B. R. 768

Binkley, D. 779

Bishop, P. S. 494, 550

Blake, T. J. 883, 884, 886, 887, 889

Blalock, T. V. 622

Blanco, J. A. 458

Blank, E. 9, 14, 24

Blankenhorn, P. R. 854, 860

Blass, J. J. 490

Blau, P. J. 278, 290, 294, 298, 337, $372,566,567,568,569,570$, $572,573,574,576,578,579$, $580,581,582$

Bleier, A. 485, 528

Boecker, W. D. 410

Bomar, E. S. 495

Bondada, B. R. 750

Bongarten, B. C. $799,816,875$

Bonk, J. J. 606

Booker, B. L. P. 433

Boring, L. R. 816

Boulet, J. A. M. 349, 356

Bowersox, T. W. 854, 860, 864

Bowker, J. C. 680

Braatne, J. H. 777, 783

Bradford, P. 25

Bradley, S. 352, 414

Bradshaw, H. D., Jr. 769, 787

Bransby, D. I. $841,868,880$

Braun, A. T. 124

Breder, K. 285

Bresnan, D. F. 797, 803

Breve, M. A. 826,843

Bridges, D. C. 804

Brinkman, C. R. 277, 282, 297, 316, $385,397,429,435$ 
Broach, R. W. 554

Broadaway, E. R. 640

Broadwater, R. P. 629,642

Bronfman, B. H. 41

Brown, J. J. 339, 350, 423

Brown, M. A. 6, 40, 53, 56, 58, 66 , $70,72,79,89,231,232,233$, $234,235,237,238,239,240$, $241,243,244,269,583,584$, $585,586,587,588,589,590$

Brown, R. H. 512, 517

Brown, R. T. 920

Brynestad, J. R. 655, 656, 660, 684, $695,715,721,722,723,724$

Budai, J. D. 548, 549, 677, 689, 708

Buljan, S. T. 351, 399, 415

Burgess, D. 848

Burghardt, R. R. 605

Burk, T. E. 793

Burns, R. 256

Burns, S. J. 676

Burrage, L. M. 607

Busche, R. M. 897, 898

Butler, J. L. 804

Buxton, D. R. 790

Byerly, R. T. 624

Byers, C. H. 905, 906, 907, 908, 909, 910,911

Cada, G. F. 915, $916,918,919,921$, 923, 924, 925, 926, 928

Cantor, R. A. 806

Caponetti, E. C. 471, 472

Carim, A. H. 701

Carlsmith, R. S. 69

Carlson, I. T. 794

Carlson, J. D. 177

Carlson, M. 845

Carmody, J. 179, 186

Carpenter, J. A., Jr. 554

Carta, G. 905, 906, 908, 909, 911

Cates, M. R. 455

Cavanagh, R. 25

Cavin, O. B. 429, 524, 529, 706

Cawley, J. 347

Ceder, G. 547

Ceulemans, R. J. 783, 878

Chakoumakos, B. C. $655,679,689$, $690,692,693,710$

Chakravarti, D. 481

Chandler, W. U. 69

Chandra, D. 744

Chandrasekaran, A. 629, 642

Chang, C. L. 346, 416

Chang, L. H. 920, 921, 924
Chao, B. S. 677

Chen, F. C. 103, 115, 125, 141, 144, $157,929,932,933,934$

Chen, G. L. 142, 144, 147, 152, 153 , 154

Chen, Y. J. 673, 679, 690

Cheng, W. K. 454

Cherney, J. H. 839

Chia, K. 343

Childs, K. W. 183, 195, 205

Childs, P. W. 166, 170, 176, 206, 226

Choi, S. R. 281

Choi, S.-I. 613, 626

Choudhury, A. 546

Christen, D. K. 548, 549, 643, 651, $655,670,671,672,673,679$, $683,685,686,687,688,689$, $690,691,692,693,699,708$, $710,711,713,716,720,724$

Christensen, S. W. 921

Christian, J. E. 163, 164, 171, 175, $177,178,185,186,187,189$, $190,191,192,193,201,223$

Christopherson, N. S. 846

Chu, F. Y. 592

Chu, W. 195

Chuck, L. 304, 334, 396

Civale, L. 643, 674, 679, 685, 690, $692,693,696,710,713,718$, 719,720

Clausing, R. E. 576

Clem, J. R. 719

Clemans, C. L. 596

Clements, K. A. 600

Clendenen, G. W. 761

Coady, S. A. 802,812

Coghlan, W. A. 503

Cole, D. R. 943, 944

Cole, D. W. 779

Cole, G. V. 802

Colletti, J. P. 807,808

Collier, R. K., Jr. 103

Collins, M. 752

Comfort, A. M. 401

Compere, A. L. 444, 469, 470, 471 , 473

Conklin, J. C. 109, 119, 120, 121, 122,130

Cookson, A. H. 605

Cooley, K. C. 518

Corbin, N. D. 327, 346, 395, 416

Cordaro, J. F. 630, 641

Counce, D. M. 101 
Courville, G. E. 163, 170, 187, 190, $198,205,206,212,213,215$, $221,224,225,226$

Cowan, R. S. 565

Craig, D. F. 941

Cranmer, D. C. 330

Creswick, F. A. 95, 151

Crosbie, G. M. 383, 393, 436

Crosswhite, R. N. 139

Crow, T. R. 852

Cuccio, J. S. 303, 329, 401

Cundiff, J. S. 821, 842, 874

Cunningham, M. 872

Curlee, T. R. 363, 555, 556, 583

Cushman, J. H. 756, 762, 784, 786, $789,809,817,823,833,851$, 853,871

D'Angelo, C. 354, 418

Dabrowski, B. 658

Dai, S. 912, 913, 914

Dale, S. J. 541, 602

Daley, J. G. 682

Daniels, W. L. $770,821,842,873$

Das, S. 363

David, S. A. 525, 562

Davis, R. F. 376, 377, 409

Davis, S. C. $23,30,50,80$

Davis, T. D. 847

Davison, B. H. $890,891,892,893$, $894,895,896,898,899,900$, 901,903

Daw, C. S. 439,445

de Fontaine, D. 547

DeAngelis, D. L. 778, 872

DeBell, D. S. 761, 879

DeCarli, J. P. 909, 910,911

DeCarli II, J. P. 905,906

Delmas, A. A. 172

Deluca, J. A. $650,668,672,683,700$

Deonigi, D. E. 70

Desjarlais, A. 0. 163, 164, 170, 197

DeVan, J. H. 474

DeVault, R. C. 92, 96, 126, 138, 143

DeVore, C. E. 573, 578, 581, 582

Diamond, R. C. 251

Dickmann, D. I. 792, 796, 852, 858

Dickson, R. E. 782, 810, 852

Didion, D. 137

Diendorfer, G. 610, 611

Dillard, D. M. 407

Dimmel, D. R. 838

Ding, J. L. 277, 297, 313

Ding, W. 744
Dinus, R. J. 838

Dinwiddie, R. B. 935

DiStefano, J. R. 494, 550

Dobbins, C. L. 835

Domingo, N. 441, 455, 456

Doshi, D. 341

Doverspike, K. 722

Downing, M. 757, 758, 759

Doyle, T. W. 853, 867

Dragoo, A. L. 412

Drake, J. B. 738

Dresner, L. 652, 654, 659, 697, 714

Dreysse, H. 547

Driver, B. 9

Duffy, S. F. 282

Dufrane, K. F. 292, 358, 391, 419

Dull, R. W. 657

Duncan, A. J. 500, 501

Duncan, C. S. 775

Dunlap, J. D. 798

Dunlap, J. M. 777, 878

Dunn, E. M. 425

Eades, R. A. 554

Easterly, C. E. 632

Ehrenshaft, A. R. 754, 762, 784, 811 , $837,869,870$

Eichler, C. H. 638

Eilts, L. E. 596

Eisenberg, J. F. 239

Elkassabgi, Y. 128

Ellingson, W. A. 338, 421

Elliott, S. R. 583

Elmore, J. L. 882

English, B. C. 751, 802, 812

English, M. 11, 20

Eom, C.-B. 708

Erickson, D. A. 804, 805

Erwin, J. 461

Eto, J. 68

Evans, D. M. 205

Everleigh, C. A. 505, 527

Faby, E. 235

Fairchild, P. D. 104, 113, 145

Fang, H. T. 274, 275, 276, 303, 329

Faulkner, J. S. 537, 561

Fear, M. P. 389, 430

Federer, J. I. 483, 486, 487, 489, $492,493,496$

Feenstra, R. 686, 687, 688, 689, 699, 708

Feero, W. E. 595, 624

Feild, C. A. 718, 720

Feirer, R. P. 838 
Felando, T. 926

Ferber, M. K. 274, 275, 276, 284, $285,311,318,331,371,392$, $398,400,937,938,939$

Ferguson, P. A. 534

Ferraro, R. J. 675

Ferri, J. L. 491

Fick, G. W. 836

Fields, B. A. 283

Figliola, A. 878

Fine, H. A. 158, 183, 188, 194, 195

Fischer, S. K. 104, 106, 107, 110, $112,113,134,135,151$

Fisher, J. T. 877

Fiskum, R. J. 124

Fitzpatrick, G. L. 41

Flanigan, C. T. 462

Foldeaki, M. 649

Foley, M. R. 288, 300, 327, 353

Fort, E. M. 605

Fortson, N. H. 633

Foster, B. E. 429

Foust, J. V. 622

Francfort, J. E. 918, 921

Franchuk, C. A. 583, 585

Frank, J. C. 208

Fraser, J. 365

Frazer, J. W. 554

Freedman, S. I. 96

Freeman, L. 269

French, C. E. 96

Fulkerson, W. 145

Fulmer, M. 100

Funkenbusch, P. D. 676

Gadoth, D. 117

Gallois, B. M. 526

Gao, F. 454

Gao, J. 332

Garbauskas, M. F. 700

Garg, A. K. 327

Gaydos, P. A. 292, 358, 391, 419

Geballe, T. H. 708

Geller, E. W. 141

George, E. P. 499, 509, 529, 542, 544

Gettings, M. B. 21, 48, 228, 230, 242, 245,267

Ginatempo, B. 533

Glicksman, L. R. 210,218

Gnadt, P. A. 627

Godia, F. 900

Goel, R. K. 53, 586, 590

Goewey, P. 260

Goins, L. F. 204
Goldberg, L. F. 255

Goldman, C. 59, 85, 86

Gommed, K. 117

Gonos, J. 269

Gonzalez, J. M. 484, 491

Goodman, W. R. 802, 812

Goodrich, S. M. 304, 334, 382, 386, 396

Goodwin, G. M. 502, 525

Goyal, A. $650,668,673,676,678$, $694,702,707$

Grado, S. C. 854,860

Graham, R. L. 757, 758, 759

Granryd, E. 120, 130

Grant, D. 382, 386

Graves, G. A. 382, 386

Graves, R. L. 385, 429, 450, 456, 462

Graves, R. S. 159, 162, 163, 165, $174,182,183,184,187,188$, $189,190,199,200,202,216$, $219,220,406$

Greene, D. K. 839

Greene, D. L. 22

Greer, M. E. 740

Griffin, F. P. 156

Griffin, G. D. 592, 632

Griffith, W. L. 444, 469, 470, 471, 473

Griggs, E. I. 209, 215

Grossman, G. 92, 93, 117

Grossnickle, S. C. 813

Grzybowski, S. 619

Gunderson, C. A. 749

Gurevich, A. 651

Gyorffy, B. L. 533, 547

Hadley, S. 1

Haissig, B. E. 847, 856, 857, 876

Hall, J. A. 264, 271

Hall, R. B. $773,774,775,788,807$, $808,814,815,819,820,848$

Hallett, F. 116

Hamby, C. 531

Hammarstrom, J. L. 346, 416

Hamrick, J. L. 875

Hanna, R. D. $774,788,814,815,820$

Hansen, E. A. 753, 791

Hansen, J. S. 346, 395, 416

Harringston, C. 25

Harris, W. M. 750

Harry, D. E. 866

Hart, E. R. 768, 773, 774, 775, 788, $814,815,819,820$

Hartford, E. H. 708 
Hartline, S. D. 417

Haselkorn, M. H. 306, 336, 360, 390, 420

Hauser, D. 347

Hausner, H. 412

Hawsey, R. A. $646,647,648,661$, $662,663,664,665,666,667$, $669,681,682,703$

Hayes, F. C. 105

Hayes, J. 89

Haynes, H. D. 156

Heatherly, L. J. 576

Hebner, R. E. 622

Hecht, N. L. 304, 334, 382, 386, 396

Heenan, P. 929

Hefter, J. 351

Heilman, P. E. 769, 783, 787, 798, 849,878

Hellman, E. S. 708

Hembree, Jr., D. M. 504

Henson, T. J. 483, 723

Hermann, A. M. 649,653

Herms, D. A. 814

Heuchelin, S. A. 820

Hewett, M. J. 255

Hicks, E. G. 41

Hicks, K. L. 624

Hill, L. J. 3, 32, 42, 49, 51

Hillis, S. L. 440, 442, 446, 447, 464, 465

Hilton, S. 382, 386

Hinckley, T. M. 769, 777, 783, 787, 878

Hindman, D. L. 483

Hirschfeld, D. A. 339

Hirst, E. 1, 2, 4, 7, 8, 9, 10, 13, 14, $15,16,17,19,21,24,25,26$, $27,29,32,34,35,36,37,38$, $41,43,44,46,48,49,51,52$, $54,55,57,58,59,60,61,62$, $65,67,68,71,73,74,75,77$, $78,82,84,85,86,88,90$

Ho, C. M. 141

Hockey, B. J. 283, 375, 399

Hodgson, J. W. 440, 442, 459, 464, 465,466

Hoenigman, J. R. 382, 386

Hoffman, M. G. 41

Holcombe, C. E. 531

Holloway, D. L. 338

Holmes, H. F. 942

Holmes, J. M. 907
Holtzberg, F. H. 643, 674, 679, 685, $690,692,693,696,713,716$, $717,718,719,720$

Hopkins, A. A. 794

Hopper, A. T. 347

Horita, J. 943,944

Horowitz, S. H. 623

Horton, J. A. 499, 509, 529, 535, $545,553,557,558,559$

Horton, L. L. 369

Horvath, E. A. 537

Host, G. E. 850, 852

Hough, R. E. 256

Howard, A. J. 908

Howell, M. 474

Hsu, H. 701, 706

Hsu, S. M. 412

Hsueh, C. H. 438, 938, 939, 940

Hu, P. S. $28,45,47,50,64,80,83$, $87,260,272$

Huang, B. Y. 540

Hubbard, C. R. 274, 524, 704, 705, $706,712,722$

Huber, D. A. 799

Huckabee, M. L. 351, 415

Hudson, T. L. 636

Huetteman, C. A. $772,781,797,803$, 822

Hughes, E. E. 763

Hughes, M. 760

Hughes, P. J. 94, 99, 100, 104, 108, 113,114

Hunsaker, D. B., Jr. 882

Huntley, W. R. 214

Huston, M. A. 778

Hwang, H. L. 248

International Energy Agency 160

Irby, M. S. 18

Isebrands, J. G. 782, 783, 793, 810, $852,858,878$

Jackson, R. L. 569

James, D. R. 592

Jang, S. D. 386

Janney, M. A. 374, 495, 530

Jenkins, M. G. 274, 275, 276, 284, $311,318,329,331,371,398$

Jenkins, V. T. 371

Johnson, A. C. 505

Johnson, C. A. 333, 422

Johnson, D. D. 533, 539

Johnson, D. R. 286, 289, 296, 314, $362,373,379,384,411,412$, 431 
Johnson, D. W. 779,827

Johnson, J. S., Jr. 470, 471

Johnson, K. D. 839

Johnson, K. H. 816

Johnson, K. J. 794

Johnson, M. A. 838

Johnston, J. W., Jr. 833, 840, 871

Jones, D. W. 916

Jones, E. C. $548,549,687,688,699$

Joslin, D. L. 405, 434

Jou, W. H. 141

Joyce, T. W. 473

Joyner, P. A. 112

Joynt, R. 651

Judkoff, R. 251

Kadyrov, E. 651

Kafka, R. J. 600

Kahl, W. K. 385, 429, 445, 463

Kaiser, A. B. 645

Kalish, Y. 359

Kang, S. 293, 368, 387, 425

Kannberg, L. D. 733

Kao, M. Y. 499, 529

Karas, P. L. 672, 683, 700

Karasek, K. R. 352, 414

Kardas, A. 732

Karnitz, M. A. 156, 264, 271, 491

Kauffield, M. 137

Kaufman, E. N. 894

Kaufman, M. J. 500, 501

Kean, J. N. 814

Keating, K. 41

Kedl, R. J. 730, 735, 747

Kee, D. D. 841,880

Keiser, J. R. 483, 569, 578

Kelkar, A. D. 332,424

Kelley, E. F. 622

Kelley, F. A. 306, 336, 390, 420

Kennedy, W. N. 605

Kenney, W. A. 862

Kerchner, H. R. 657, 672, 679, 686, $690,691,692,693,710,713$, 716

Keshock, E. G. 132

Ketcham, T. D. 549

Keyes, B. L. P. $280,291,322,323$, $324,380,388$

Khandelwal, P. K. 311, 328, 413

Kiggans, J. O. 287, 315, 530

Kim, H. 293, 354, 387, 486

Kim, K. 293, 387

Kim, K. S. 425, 750

Kimrey, H. D. 530

Kin, Y. C. 724
King, T. 499

Kinney, L. F. 232, 233

Kirk, M. A. $696,718,719,720$

Kirmse, R. D. 877

Kirol, L. 728

Klabunde, C. E. $672,686,688,690$, 699

Kladivko, E. J. 839

Klareich, F. H. 208

Klatt, L. N. 479,480

Klein, K. W. 602

Klopfenstein, N. B. 820

Knoke, G. S. 141

Koch, C. C. 552

Kodas, T. T. 701

Koehler, W. C., Jr. 240

Koester, D. A. 376, 377, 409

Kolb, J. O. 233, 245, 251, 265

Kollie, T. G. 162, 168, 183, 195, 203

Kondolf, G. M. 926

Kontra, R. 694

Korus, R. A. 881

Krarti, M. 205

Krause, F. 85, 86

Krause, R. 330

Kroeger, D. M. 650, 656, 668, 676, $678,694,695,701,702,706$, $707,715,722,723,724,725$

Kruse, V. J. 606, 616, 618

Krusin-Elbaum, L. 696, 713, 718, 719

Kuman, K. 205, 510, 511

Kunsmann, H. 499

Kurka, K. 632

Kweller, E. 125

Kyle, D. M. 164, 930, 931, 932, 933, 934

Kyriacou, C. I. 361

Labs, K. 186

Lai, J. S. 634

Laing, P. M. 451

Landrum, H. L., Jr. 195

Landsberg, J. J. 885

Larbalestier, D. C. 651

Lathwell, D. J. 836

Lau, S. K. 301, 343

Lauf, R. J. 505, 527, 531

Laughlin, K. 830

Lavan, Z. 103

Lawler, J. S. 608, 617, 627, 633, 634,639

Lay, K. W. 548, 549, 691, 700

Layton, P. A. 853, 862, 867

Ledin, S. 845 
Lee, E. H. 497, 503, 504, 507, 509, $513,516,521,536,553$

Lee, S. L. 509

Lee, Y. 516

Legro, J. R. 638

Leiby, P. N. 22

Levins, W. P. 156, 241, 252, 261, 264,271

Lewis, M. B. 497, 503, 507, 521, 536

Lewis, P. J. 101

Li, C.-W. 302, 326, 340

Li, T. K. 339

Lilley, E. 345, 355, 428

Lin, C.-K. J. 284, 318

Lin, H. T. 408

Lindberg, S. E. 779

Lindemer, T. B. 723

Linders, J. R. 624

Ling, J. 338

Linkous, R. L. 163, 187, 190, 478, 479,480

List, F. A. 706

Litzinger, T. A. 443, 457, 460, 462

Liu, C. T. 499, 500, 510, 511, 515 , $519,523,525,532,534,542$, $544,552,553,559$

Liu, H. T. 141

Liu, K. C. $277,297,313,385,397$, $424,429,435,437$

Liu, T. K. 625

Liu, W. 399

Liu, Z. 796

Lizzio, A. 471

Loewen, K. H. 802

Lothner, D. C. 863

Loutfy, R. O. 481, 482

Love, P. M. 204, 221

Lovett, G. M. 779

Lovins, A. 25

Low, J. J. 554

Lowden, R. A. 518, 936, 937

Lowenberg-DeBoer, J. 835

Lowndes, D. H. 548, 549, 687, 688, $689,699,708$

Loxton, C. M. 545

Lstiburek, J. 179

Lucas, B. N. 721

Lux, A. E. 619

Luxmoore, R. J. 872

Lyle, F. F., Jr. 468

Lynd, L. R. 817, 851, 898

MacDonald, J. M. 108, 209, 228, 230, $236,251,254,263,267,270$, 273,621
Macey, S. M. 66

Macriss, R. A. 146

Maguire, M. C. 562

Mahajan, S. M. 591

Mahler, K. A. $804,805,865$

Major, C. H. 72

Major, J. E. 813

Major, R. W. 613, 626

Majumdar, B. S. 347, 427

Malcolm, E. W. 838

Malghan, S. G. 307

Malozemoff, A. P. $674,713,716,718$, 720

Mamantov, G. 912, 913, 914

Mangels, J. 344

Mansur, L. K. 497, 503, 504, 516, 521,536

Marland, G. 844

Marsh, G. C. 723

Martin, R. L. 371,398

Martin, S. A. 756,762

Marwick, A. D. $643,674,679,685$, $690,692,693,696,710,713$, $716,719,720$

Masterson, D. 467

Mathiprakasam, B. 157, 929

Matijasevic, V. C. 708

Mattson, J. A. 846

Maybee, C. 836

Maziasz, P. J. 502, 506, 524, 525

Mazzucchi, R. P. 251

McBrayer, J. F. 882

McBride, M. F. 191

McCamy, J. W. 549

McCarthy, J. F. 818

McCauley, J. W. 412

McClung, R. W. 299, 309, 314, 316, 551

McCluskey, P. H. 406

McConnell, B. W. 594, 603, 607, 675

$\mathrm{McCool}$, J. I. 577

McCown, B. H. 876

McCoy, H. E., Jr. 612

McCullum, D. E. 304, 334, 382, 386, 396

McElfresh, M. W. 674, 720

McElroy, D. L. $159,162,163,165$, $182,183,184,187,188,190$, $194,195,196,199,200,203$, 219,538

McEntee, J. 142

McEvers, J. A. 489

McFarland, M. 106 
McGill, R. N. 440, 442, 446, 447, $449,459,464,465$

McHargue, C. J. 312, 369, 370, 434

McKamey, C. G. 502, 515, 524, 558

McKenna, J. R. 873

McLain, H. A. 108, 249, 253

McLaughlin, S. B. 762, 767, 784

McLinden, M. 137

McMahon, B. G. 774,788

McMahon, J. E. 69

McMurtry, C. H. 320

McNabb, H. S., Jr. 773, 774, 788, $819,820,859$

McNabb, W. A. 762, 784

Mdafri, A. 835

Meckler, G. 103

Mehoskie, B. L. 410

Mei, V. C. $103,115,123,125,136$, $144,155,157,929,932,933$, 934

Menon, M. N. 274, 275, 276

Mesmer, R. E. 942

Miaou, S.-P. 28

Michael, D. A. 852, 858

Michaels, H. 41

Michell, M. J. 779

Michels, E. 239

Mihlmester, P. E. 12, 240, 269

Mikijelj, B. 344

Miller, C. W., Jr. 341, 366

Miller, D. B. 597, 619

Miller, J. H. 518

Miller, M. K. 500, 501

Miller, R. G. 184

Miller, W. A. $148,150,156$

Minor, D. B. 307

Minton, N. A. 843

Misuriello, H. 268

Mitchell, C. P. 824

Mitchell, W. 443

Mixon, W. R. 251, 268

Mize, C. 807,808

Mizuhara, H. 425

Modahl, R. J. 105

Modine, F. A. 613, 615, 626, 630, 641

Monteen, L. D. 634

Moodera, J. S. 700

Moore, K. J. 794

Moore, N. L. 70

Moorhead, A. J. 486

More, K. L. 274, 277, 376, 377, 378, 409

Morel, T. 348

Morris, M. D. 30
Morrison, H. D. 592

Mosjidis, J. A. 765

Motakef, S. 210, 218

Moy, C. A. 734, 745

Mukherjee, A. K. 546

Mulroy, W. 137

Mundy, J. N. 658

Murphy, R. W. 132, 141, 144

Mutsuddy, B. C. 427

Myers, G. H. 96

Myers, W. E. 596

Nadel, S. 41

Natansohn, S. 317, 321, 394

National Planning Committee for District Heating, Cooling and Cogeneration 227

Naylor, M. G. S. 325, 335, 389, 430

Neff, H. P., Jr. 631

Nehmadi, M. 622

Neil, J. T. 351, 415

Nelson, G. D. 255

Nelson, N. D. 858

Nelson, W. R. 639, 640

Netzer, D. 753

Newson, D. 326, 340

Nguyen, P. V. 796

Nichol, J. 624

Nichols, R. J. 817, 851

Nicholson, D. M. C. 512, 514, 517 , $533,537,539,547,561$

Nicholson, J. M. 383, 393, 436

Nickel, D. L. 606

Nijhawan, S. 936

Noble, M. T. 255

Nolan, T. A. 274

Norby, R. J. 748, 764, 776, 827, 828

Nordh, N. E. 845

Norton, D. P. $548,549,688,689$, 699,708

Noun, R. J. 70

Nyangito, H. O. 751

O'Hern, M. E. 721

O'Neil, D. 293, 319, 387

Oblas, D. W. 354,418

Occhionero, A. J. 114

Ohriner, E. K. 558

Oliver, B. F. 540

Oliver, W. C. $405,434,516,540$, 560,721

Olszewski, M. 726, 738

Olthoff, J. K. 592

Omatete, O. O. 374, 485, 488, 528

Ong, E. T. 732

Oommen, T. V. 605 
Oosterhuis, D. M. 750

Ossandon, J. G. 655, 691, 692, 693, 711,716

Ostry, M. E. 753, 845, 859

Otto, R. G. 927

Pace, M. 0. 622

Paille, N. I. $288,300,327$

Pak, J. J. 308

Palmer, D. A. 945,946

Palumbo, J. H. 460

Paranthaman, M. 644, 645, 649, 653, $655,660,684$

Park, E. 347

Parrish, D. J. 770, 821, 842, 873, 874

Pasto, A. E. 317, 321, 394

Patten, D. 0.426

Patterson, M. R. 139

Patton, J. B. 608, 617, 633, 634, 639

Paulson, T. E. 341, 366

Pawel, J. E. 312, 369, 370

Pedersen, C. R. 170

Pelletier, P. J. 288, 300, 327, 345

Peng, T.-H. 780

Perez-Blanco, H. 128, 139

Perlack, R. D. 6, 755, 785, 801

Peters, J. S. 41

Petersen, S. R. 217

Peterson, C. L. 881

Petri, R. 732

Petrich, C. H. 923

Petrie, T. W. 170, 226

Pettifor, D. G. 559

Petty, D. G. 814

Pfeifer, R. A. 836

Phadke, A. G. 623

Phillips, B. A. 126, 131

Phillips, J. M. 686

Pih, H. 437

Pinski, F. J. 533, 539

Ploetz, K. L. 287

Poirier, C. 743

Pollinger, J. P. 302, 326, 338, 340, 421

Pompe, R. 412

Porter, W. D. 506, 706

Post, W. M. 872

Povirk, G. L. 558

Power, M. 237, 239

Preckel, P. 835

Predmesky, R. L. 383, 393, 436

Preece, J. E. 772, 781, 797, 803, 822

Pregitzer, K. S. 792, 796

Prindle, B. 56
Pujari, V. K. 288, 300, 327, 346, $365,395,416,417$

Quinn, G. D. 310, 316, 367, 381

Raab, J. 33, 39

Rackliffe, G. B. 616

Railsback, S. F. 920, 921, 922, 923 , 924

Ranney, J. W. 755, 760, 762, 784, $785,795,801,823,824,853$, 867

Rao, G. R. 497, 504, 513, 521

Rauscher, H. M. 850, 852

Raymer, P. L. 804, 805, 826, 843

Reardon, B. J. 704, 705, 712

Rebello, W. J. 491

Rebenne, H. E. 354, 418

Reddy, C. S. 456

Reed, D. A. 631

Reed, J. H. 41, 629, 640, 642

Reid, E. A. 114

Reiner, R. H. 478

Resetar, T. M. 412

Rice, C. K. 97, 111, 133

Richerson, D. W. 295

Richlen, S. L. 941

Riecke, G. T. 127

Riester, L. 936

Rinehart, B. N. 921

Rizy, C. G. 806

Rizy, D. T. 596, 603, 608, 617, 633, 634,639

Robbins, B. 605

Robins, J. R. 592

Robinson, D. A. 255

Rockefeller, G. D. 624

Rockenfeller, U. 728, 737

Rogers, R. S. C. 410

Roke, L. 116

Romana, L. J. 369, 370

Ronnberg-Wastljung, A. 845

Rose, P. A. 880

Rosenfield, A. R. 347

Rossi, G. A. 345, 346, 353, 355, 395, $416,426,428$

Roth, P. L. 772, 797, 803, 822

Rothman, S. J. 658

Rourke, W. J. 317

Routbort, J. L. 658

Rowe, J. 25

Rubinstein, M. 601, 620

Ruggles, M. B. 490

Rule, L. 807,808

Russell, M. 801

Rust, W. W. 175 
Sabo, C. 38,44

Salama, K. 702

Salas, T. M. 599

Sale, M. J. 915, 917, 921, 922, 923, 924, 926, 927

Salem, J. A. 281

Sales, B. C. $679,690,691,692,693$, 710

Sales, L. C. 288, 300, 327, 365

Salyer, I. 742

Sand, J. R. 97, 98, 107, 112, 120, $133,134,149,150$

Sanders, R. R. 311

Sands, S. H. 625

Sankar, J. 332, 424

Santana, E. A. 739

Santavicca, D. A. 443

Santella, M. L. $308,364,508,520$, 562

Santini, D. J. 69

Sarin, V. K. 354, 418

Sauers, I. 591, 592, 632

Saunders, H. E. 605

Saxonis, W. 41

Scarascia-Mugnozza, G. 783, 878

Scarbrough, J. 0.723

Schaefer, G. E. 412

Schaffhauser, A. 5

Scherr, M. I. 56

Schienle, J. L. 352, 414

Schneibel, J. H. 498

Schneider, T. R. 541

Schoch, K. F., Jr. 605

Schon, A. 41

Schubert, T. H. 864,879

Schulte, P. J. 878

Schultz, D. 807,808

Schultz, R. C. 773

Schulz, R. B. 296

Schweitzer, M. 11, 20, 32, 33, 39, $49,51,61,68,73$

Scofield, M. P. 196

Scott, C. D. $891,893,894,895,898$, 900, 902, 904

Scott, T. C. 891

Sederoff, R. R. 866

Sefer, N. R. 461

Sekula, S. T. 724

Sellmer, J. C. 876

Selvamanickam, V. 702

Selverian, J. H. 293, 319, 368, 387

Sennerby-Forsse, L. 862

Sepulveda, J. L. 361

Sernyk, J. L. 805
Seybold, K. G. 303, 329

Shaakir-Ali, J. A. 923

Sharp, T. R. 209, 247, 251, 254, 263, 267,273

Shaw, J. H. 607, 637

Shelton, W. A. 514, 533

Shelton, W. A., Jr. 539

Shen, L. S. 255

Shim, Y. 641

Shipp, P. H. 226

Shonder, J. A. 118

Shonka, D. B. 80

Siebein, K. N. 346, 395, 416

Sikka, V. K. 515, 546, 553

Silver, M. N. 613, 626

Simonson, J. M. 945

Simpson, W. A. 429

Simpson, W. A., Jr. 309, 551

Sinha, A. 424

Sircar, A. 742

Sisson, W. G. 909, 910,911

Sivers, E. A. 338

Skadberg, A. 807, 808

Sladden, S. E. 841, 868, 880

Sluiter, M. 533

Smith, B. 878

Smith, I. M. 917

Smith, J. D. B. 605

Smith, S. A. 70

Smith, T. L. 177

Snelson, W. K. 95

Snoha, D. J. 381

Solidum, E. 302, 326, 340, 352

Solomon, A. D. 738, 741

Sommers, G. L. 921

Sparks, C. J. 499, 529

Specht, E. D. 650, 668, 724

Spooner, S. 472

Srinivasan, G. V. 301,343

Srinivasan, S. 278

St. Julien, D. 549

Stansbury, E. E. 180, 181, 207

Starr, T. L. 518

Statt, T. G. 149

Staunton, J. B. 533

Stejic, G. 651

Stettler, R. F. 769, 777, 783, 787, $798,849,878$

Stewart, W. E., Jr. 736, 740

Stickler, L. A. 740

Stiel, L. I. 739

Stiles, E. D. 436

Stinton, D. P. 295

Stocks, G. M. 514, 533, 539, 547 
Stoloff, N. S. 552

Stone, T. A. 102

Storm, R. S. 301, 343, 410

Stovall, J. P. 600, 602, 609

Stovall, T. K. 729, 747

Strand, R. F. 864

Stranford, G. 352

Strang, S. G. 23

Strauss, C. H. 825, 854, 860, 861

Strehlow, R. A. 374

Stricklett, K. L. 592

Stucky, D. 835

Subramaniam, C. K. 645

Sullivan, R. 115

Sullivan, R. A. 930

Sullivan, T. M. 342

Sumner, D. R. 843

Sun, Y. R. 643, 655, 656, 660, 673, $674,679,684,685,690,691$, $692,693,695,710,711,713$, $716,717,719$

Sundberg, G. J. 346, 353, 395, 426

Surles, S. E. 875

Sutliff, J. A. 650

Svec, O. J. 91

Swab, J. J. 381, 402, 403, 432

Swain, M. N. 458

Swain, M. R. 458

Swanson, R. E. 423

Swartz, S. L. 347, 427

Swihart, J. C. 517

Szotek, Z. 514

Takeyama, M. 532

Tang, Z. 800

Taub, A. I. 552

Taylor, E. R., Jr. 603, 606

Taylor, M. J. 738

Tello, R. 649

Temmerman, W. M. 514

Ten Eyck, M. O. 320

Tennery, V. J. 371, 398, 400

Ternes, M. P. 241, 247, 248, 249, $250,251,252,260,261,266$, 272

Tesche, F. M. 593, 594, 598, 603, $614,618,625,628,635$

Tewari, P. H. 417

Thacker, L. S. 168

Thoma, P. 529

Thomas, D. E. 599

Thomas, D. L. 826,843

Thomas, J. F. 439

Thompson, J. C. 629
Thompson, J. E. $890,892,896,901$, 904

Thompson, J. R. $643,655,656,660$, $670,671,673,674,679,684$, $685,686,687,688,690,691$, $692,693,695,696,699,710$, $711,713,716,717,718,719$, 720,724

Thomson, J. 0. 710

Thornbur, R. W. 820

Thorp, J. S. 623

Thrill, D. C. 804,805

Tiegs, T. N. 287, 315, 392, 404, 406, $407,438,488,558$

Tkaczyk, J. E. $650,668,672,683$, $686,691,700$

Tksczyk, J. E. 548, 549

Todd, D. E. 827

Tolsted, E. 753

Tomlinson, J. J. 727, 731, 733, 735, 738,746

Tonn, B. 5

Tortorelli, P. F. 494, 550, 936

Tracey, D. M. 288, 300, 327

Triolo, R. 471, 472

Tschaplinski, T. J. 748, 749, 764, $771,776,813,818,827,828$, $883,884,886,887,889$

Tucker, W. T. 333, 422

Tuluca, A. N. 205

Turchi, P. E. A. 533

Turhollow, A. F. 751, 762, 784, 809, $829,833,844,853,871$

Tuskan, G. A. 749, 762, 766, 771 , 784,830

Tye, R. P. 197, 205

Uman, M. A. 601, 611, 620

Vaccari, D. L. 328,413

Vahlas, C. 698,709

Vaidyanathan, R. 332

Van Brunt, R. J. 592

Van Dyke, J. W. 594

Van Miegroet, H. 748, 779

Van Volkenburg, E. 878

Vance, E. F. 594, 598

Vance, M. C. 495

Vaughan, D. H. 821, 842, 874

Venezia, A. M. 545

Venkateswaran, V. 410

Veverka, E. F. 607

Vincent, R. J. 140

Vineyard, E. A. $98,109,116,119$, $121,122,129,149,150$ 
Violette, D. M. 41

Vogel, K. P. 794

Voldrich, W. 357

Volenec, J. J. 839

Vonier, T. 205

Vories, R. 229

Voshall, R. E. 605

Voss, M. K. 171

Waddle, D. B. 621

Wade, J. A. 353

Wade, J. C. 303, 329

Wagner, C. L. 595, 624

Wagner, R. M. 439

Wahiduzzaman, S. 348

Waldman, D. J. 448, 452

Waldron, W. 127, 140

Wang, J. S. 365

Wang, J. T. 913

Wang, Z. L. 513, 650, 656, 668, 678, $694,695,707$

Ward, C. Y. 880

Ward, T. L. 701

Warren, J. W. 526

Warwick, W. H. 404

Wasserman, D. M. 270

Watson, M. A. 361

Watts, J. A. 923

Watts, R. L. 70

Wayne, S. F. 319

Weaver, F. J. 163, 165, 182, 183, $190,195,199,203,538$

Weaver, R. S. 204

Webb, J. W. 923

Weiss, C. D. 390

Weiss, D. 420

Weiss, P. 79

Wendt, R. L. 163

Wereszczak, A. A. 285, 311, 937, 938

Werst, S. H. 195

Wert, J. J. 369, 370

Wesolowski, D. J. 943, 944, 946

West, B. H. $385,440,442,444,446$, 447, 464, 465

Westmoreland, C. G. 485,528

Wetherington, G. R. 640

Whalen, P. 326, 340

Wheeler, R. 696

Wheeler, R. B. 615,641

White, D. L. $12,18,40,56,81,229$, $233,244,246$

Whitesell, C. D. 864,879

Whitlow, G. A. 680

Wiard, B. M. 783,878

Wiederhorn, S. M. 283, 330, 375, 399
Wiel, S. 25

Wiggins, C. M. 599

Wilcox, B. A. 191

Wilk, M. 93

Wilkes, K. E. 159, 166, 170, 172 , $176,211,249,251,257,258$, 259, 262, 265

Williams, F. 913

Williams, L. S. 47, 64, 83, 87, 260

Williams, R. K. 406, 656, 658, 695, $715,721,722,723$

Willkens, C. A. 288, 300, 327, 346, 416

Wilson, C. R. $6,584,585,587$

Wilson, D. F. 474, 578

Wilson, T. C. 233

Winer, W. O. 565

Winslow, S. G. 279

Winsor, R. E. 451

Wintenberg, A. L. 622

Withers, J. C. 481

Witherspoon, M. J. 239

Wittmer, D. E. 341,366

Wolf, D. D. $770,821,842,873$

Wolf, J. D. 382, 386

Wolf, S. M. 541

Wolfe, A. K. 31

Wong, P. S. 421

Wong, V. W. 454

Woodward, J. A. 904

Worthington, T. K. 696, 713, 718, 719,720

Wray, P. 807,808

Wright, L. L. $754,756,762,763$, $784,785,786,811,824,825$, $831,832,837,853,855,861$, $867,869,885,888$

Wright, N. 834

Wright, T. 244

Wu, D. C. 274, 275, 276

Wu, F. J. 353, 426

Wullschleger, S. D. 750,776

Wyman, C. E. 817, 851

Yamanis, J. 302, 326, 340

Yaney, P. 382, 386

Yang, H. 517

Yang, Y. P. 339

Yarbrough, D. W. 163, 165, 167, 169, $174,182,184,188,189,190$, $199,200,202,216,219,220$, 538

Yeckley, R. L. 288, 300, 327

Yeh, H. C. 302, 326, 338, 340, 352, 414,421 
Young, A. C. 488

Young, J. P. $912,913,914$

Young, J. R. 28

Young, R. T. 677, 689

Yourstone, E. 20, 21, 31, 48, 61, 68

Yuhas, D. 352

Yust, C. S. 563, 564, 571, 575, 576

Zacharia, T. 502, 524

Zaltash, A. 476, 477, 478, 479, 480

Zarr, R. R. 184

Zasada, J. C. 761

Zawacki, T. S. 146

Zhu, S. $686,687,688,699$

Zilberstein, G. 415

Zinkle, S. J. 536 


\section{Internal Distribution}

\begin{tabular}{|c|c|c|}
\hline $\begin{array}{l}\text { L. J. Allison } \\
\text { S. W. Allison } \\
\text { R. J. Andermann, Jr. } \\
\text { P. Angelini } \\
\text { O. A. Basaran } \\
\text { V. D. Baxter } \\
\text { P. J. Blau } \\
\text { A. Bleier } \\
\text { M. D. Boring } \\
\text { C. R. Boston } \\
\text { R. A. Bradley } \\
\text { C. H. Brown } \\
\text { M. A. Brown } \\
\text { R. A. Buhl } \\
\text { C. P. Chihasz } \\
\text { A. Choudhury } \\
\text { J. E. Christian } \\
\text { H. E. Clark } \\
\text { S. M. Cohn } \\
\text { J. L. Cook } \\
\text { J. W. Cooke } \\
\text { D. Copinger } \\
\text { J. M. Corum } \\
\text { J. M. Cosgrove } \\
\text { G. E. Courville } \\
\text { J. Coyner } \\
\text { J. H. Cushman } \\
\text { B. H. Davison } \\
\text { A. O. Desjarlais } \\
\text { J. Dickerman } \\
\text { N. Domingo } \\
\text { P. D. Fairchild } \\
\text { T. D. Ferguson } \\
\text { S. K. Fischer } \\
\text { C. Forsberg } \\
\text { W. Fulkerson } \\
\text { R. L. Graves } \\
\text { T. Grizzard } \\
\text { C. A. Gunderson } \\
\text { R. M. Harrington } \\
\text { R. A. Hawsey } \\
\text { S. G. Hildebrand } \\
\text { L. J. Hill } \\
\text { W }\end{array}$ & $\begin{array}{l}44 . \\
45 . \\
46 . \\
47 . \\
48 . \\
49 . \\
50 . \\
51 . \\
52 . \\
53 . \\
54 . \\
55 . \\
56 . \\
57 . \\
58 . \\
59 . \\
60 . \\
61 . \\
62 . \\
63 . \\
64 . \\
65 . \\
66 . \\
67 . \\
68 . \\
69 . \\
70 . \\
71 . \\
72 . \\
73 . \\
74 . \\
75 . \\
76 . \\
77 . \\
78 . \\
79 . \\
80 . \\
81-130 . \\
131 . \\
132 . \\
133 . \\
134 . \\
135 .\end{array}$ & $\begin{array}{l}\text { E. Hillsman } \\
\text { P. J. Hughes } \\
\text { M. G. Jenkins } \\
\text { R. L. Jolley } \\
\text { L. Jung } \\
\text { M. A. Karnitz } \\
\text { M. J. Kass } \\
\text { E. N. Kaufman } \\
\text { S. B. Kennedy } \\
\text { H. T. Kerr } \\
\text { T. Klasson } \\
\text { R. P. Krishnan } \\
\text { M. A. Kuliasha } \\
\text { E. H. Lee } \\
\text { N. E. Lee } \\
\text { W. Y. Lee } \\
\text { K. C. Liu } \\
\text { R. A. Lorenz } \\
\text { P. M. Love } \\
\text { G. M. Ludtka } \\
\text { G. Mackiewicz-Ludtka } \\
\text { G. Marland } \\
\text { W. R. Martin } \\
\text { J. R. Mayotte } \\
\text { E. W. McDaniel } \\
\text { R. N. McGill } \\
\text { R. McMahon } \\
\text { V. C. Mei } \\
\text { G. E. Michaels } \\
\text { S. Michaud } \\
\text { W. R. Mixon } \\
\text { M. T. Naney } \\
\text { R. J. Norby } \\
\text { R. E. Norris } \\
\text { S. D. Nunn } \\
\text { D. G. O'Connor } \\
\text { C. E. Oliver } \\
\text { B. G. Oody } \\
\text { L. J. Ott } \\
\text { J. T. Parks } \\
\text { A. Pasto } \\
\text { R. D. Perlack } \\
\text { M. J. Peterson } \\
\text { M }\end{array}$ \\
\hline
\end{tabular}




\begin{tabular}{|c|c|c|c|}
\hline $\begin{array}{l}136 . \\
137 . \\
138 . \\
139-143 . \\
144 . \\
145 . \\
146 . \\
147 . \\
148 . \\
149 . \\
150 . \\
151 . \\
152 . \\
153 . \\
154 . \\
155 . \\
156 . \\
157 . \\
158 . \\
159 . \\
160 .\end{array}$ & $\begin{array}{l}\text { L. P. Phillips } \\
\text { M. H. Rawlins } \\
\text { D. D. Rhew } \\
\text { C. K. Rice } \\
\text { D. T. Rizy } \\
\text { M. J. Sale } \\
\text { R. Sanders } \\
\text { A. C. Schaffhauser } \\
\text { T. W. Schmidt } \\
\text { E. Schorn } \\
\text { W. E. Schramm } \\
\text { R. E. Schreiber } \\
\text { R. N. Scogin } \\
\text { T. C. Scott } \\
\text { P. S. Sklad } \\
\text { E. J. Soderstrom } \\
\text { B. M. Sorensen } \\
\text { G. W. Strandberg } \\
\text { V. J. Tennery } \\
\text { P. T. Thornton } \\
\text { V. R. Tolbert }\end{array}$ & $\begin{array}{l}161 . \\
162 . \\
163 . \\
164 . \\
165 . \\
166 . \\
167 . \\
168 . \\
169 . \\
170 . \\
171 . \\
172 . \\
173 . \\
174 . \\
175 . \\
176 . \\
177-78 . \\
179 . \\
180 . \\
181 . \\
182 .\end{array}$ & $\begin{array}{l}\text { J. J. Tomlinson } \\
\text { C. Trettin } \\
\text { K. H. Vaughan } \\
\text { C. D. Warren } \\
\text { D. A. Waters } \\
\text { J. A. Watts } \\
\text { J. R. Weir } \\
\text { A. Wereszczak } \\
\text { D. L. White } \\
\text { J. Whitefield } \\
\text { T. J. Wilbanks } \\
\text { K. A. Williams } \\
\text { G. M. Wood } \\
\text { H. D. Wooten } \\
\text { S. B. Wright } \\
\text { R. E. Ziegler } \\
\text { Laboratory Records } \\
\text { Laboratory Records-RC } \\
\text { ORNL Patent Office } \\
\text { Central Research Library } \\
\text { Document Reference Sect. }\end{array}$ \\
\hline
\end{tabular}

\section{External Distribution}

183. Henry Amistadi, RR 2, Box 2191C, Brunswick ME 04011

184. John Andre, NRECA, Norris Memorial Library, 1800 Massachusetts Avenue, NW, Washington DC 20036

185. Stuart Baird, ICLEl, 8th Floor, East Tower, City Hall, 100 Queen Street West, Toronto, Ontario M5H 2N2

186. David Barraco, LightStat, 15 Canton Spring Road, Canton CT 06019

187. Jerry Bellucci, Applied Economics Research, 299 Broadway, Suite 803, New York NY 10007

188. Belinda Chan, Gas Marketing Department, Consolidated Edison, Four Irving Place, Room 305, New York NY 10003

189. James Close, HouseWarming Program Manager, Southeastern Idaho Community Action Agency, P. O. Box 940, Pocatello ID 83204

190. Louis V. Divone, Acting Deputy Assistant Secretary for Building Technologies, EE-40, FORS, U.S. Department of Energy, 1000 Independence Avenue, SW, Washington DC 20585 
191. Howard Geller, Executive Director, American Council for an EnergyEfficient Economy, Suite 801, 1001 Connecticut Avenue, NW, Washington, D. C. 20036

192. Thomas J. Gross, Deputy Assistant Secretary for Transportation Technologies, EE-30, FORS, U.S. Department of Energy, 1000 Independence Avenue, SW, Washington DC 20585

193. Mary Ann Hamm, 1225 17th Street, Suite 700, Denver CO 80202

194. Donna Hawkins, Office of Building Technologies, EE-40, FORS, U.S. Department of Energy, 1000 Independence Avenue, SW, Washington DC 20585

195. Ann Hegnauer, Office of Transportation Technologies, EE-30, FORS, U.S. Department of Energy, 1000 Independence Avenue, SW, Washington DC 20585

196. Richard Hirsh, Department of History, VPISU, Blacksburg VA 240610117

197-200. B. Kavanaugh, Center for Energy Studies, Louisiana State University, Baton Rouge LA 70803-0301

201. Dan Kotin, University of California-Los Angeles, 1811 South Shenandoah, Los Angeles CA 90035

202. Mark Levine, Applied Science Division, Lawrence Berkeley Laboratory, Building 90-4000, One Cyclotron Road, Berkeley CA 94720

203. Peter O'Farrell, Oakhurst Associates, 26 Rockmont Road, Arlington MA 02174

204. Ms. Marsha L. Quinn, Office of Industrial Technologies, Energy Efficiency and Renewable Energy, U.S. Department of Energy, 1000 Independence Avenue, SW, Washington DC 20585

$205 . \quad$ T. V. Ramachandra, Centre for Ecological Sciences, Indian Institute of Science, Bangalore, 560012 India

206. Mary Rouleau, AARP State Legislative Department, Utility Issues, 601 E Street, NW, Washngton DC 20049

207. Tish Russell, 2222 222nd Street SE, Bothell WA 98021

208-210. Don Sample, USDOE, OSTI, P. O. Box 62, Oak Ridge TN 378319939 
211. Dr. R. L. San Martin, Deputy Assistant Secretary for Utility Technologies, EE-10, FORS, U.S. Department of Energy, 1000 Independence Avenue, SW, Washington DC 20585

212. Ms. Cathy Short, Office of Utility Technologies, EE-10, FORS, U.S. Department of Energy, 1000 Independence Avenue, SW, Washington DC 20585

213. Judy Spinner, Kansas City Power \& Light Company, Department of Regulatory Affairs, 1201 Walnut, 20th Floor, Kansas City MO 64106

214. Frank M. Stewart, Jr., Deputy Assistant Secretary for Technical and Financial Assistance, EE-50, FORS, 1000 Independence Avenue, SW, Washington DC 20585

215. Andrew Stirling, Energy Group, Science Policy Research Unit, Mantell Building, University of Sussex, Falmer, East Sussex

216. Alan J. Streb, Deputy Assistant Secretary for Industrial Technologies, EE-20, FORS, U.S. Department of Energy, 1000 Independence Avenue, SW, Washington DC 20585

217. Linda Testa, SRC, 111 Presidential Boulevard, Suite 127, Bala Cynwyd PA 19004

218. Pamela Torres, Electric Power Research Institute, Room 6-113, 3412 Hillview Avenue, Palo Alto CA 94303

219. Phillip Wemhoff, T-7, Jacksonville Electric Authority, 21 West Church Street, 7th Floor, Jacksonville FL 32202

220. Andrew Wynn, EC Division, SHS 130, Augusta ME 04333

221. Office of the Assistant Secretary for Energy Efficiency and Renewable Energy, EE-1, FORS, U.S. Department of Energy, 1000 Independence Avenue, SW, Washington DC 20585

222. Office of the Assistant Manager for Energy Research and Development, DOE/ORO, P. O. Box 2008, Oak Ridge TN 37831 6269

223-224. Nancy Cleland, Office of Scientific and Technical Information, USDOE, P. O. Box 62, Oak Ridge TN 37831

225-263. Office of Scientific and Technical Information, USDOE, P. O. Box 62, Oak Ridge TN 37831 